\title{
ACÚMULO DE TREALOSE EM LINHAGENS DE Saccharomyces TERMOTOLERANTES
}

\section{DENISE APARECIDA DELGADO Bióloga}

Orientador: Prof. Dr. LUIZ EDUARDO GUTIERREZ

\begin{abstract}
Dissertação apresentada à Escola Superior de Agricultura "Luiz de Queiroz", da Universidade de São Paulo, para obtenção do título de Mestre em Agronomia, Área de concentração: Microbiologia Agrícola.
\end{abstract}

PIR A C I C A B A

Estado de São Paulo - Brasil

Outubro - 1993 
Ficha catalcorafica preparada pela Seçáa de Livros da Divisáo de Biblioteca E Documentafáo - FCidiusF

\section{Delgado, Denise Aparecida}

DS52a Acumulo de trealose en linhagens de Saccharomyces termotolerantes. Firacicaba, 1993. $105 p$.

Diss. (Mestre) - ESALQ

Bibliografia.

1. Etanol - Froducăo 2. Fermentabăo alcodica - Tem peratura 3. Levedura - Fesistencia termica 4. Levedura termofila - Fermentaça 5 . Trealose em levedura termófila I. Escola Superiar de Agricultura Luiz de Queiroz Firacicaba 
ACUMULO DE TREALOSE EM LINHAGENS DE SACCHAROMYCES TERMOTOLERANTES

Denise Aparecida Delgado

Aprovada em: 25.11.1993

Comissão Julgadora:

Prof. Dr. Luiz Carlos Basso

ESALQ/USP

Profa Dra Dejanira Franceschi de Angelis UNESP/Rio Claro

Prof. Dr. Luiz Eduardo Gutierrez ESALQ/USP

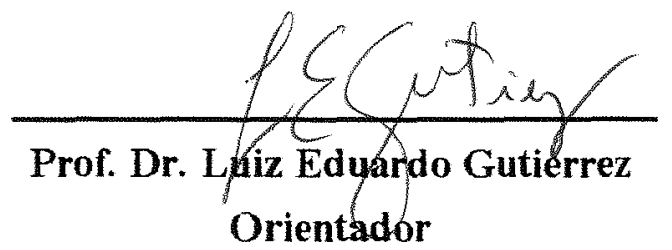


Aos meus Pais

Argemiro e Rosalina,

DEDICO. 


\section{AGRADECIMENTOS}

Ao Prof. Dr. Luiz Eduardo Gutierrez Professor Titular do Departamento de Quimica, pela orientação, incentivo e amizade.

to Departamento de Química/ESALQ/USP.

to Prof. Dr. Paulo Cesar Vertoni, do Departamento de Ciência e Tecnologia Agroindustrial pelo fornecimento das leveduras utilizadas no presente trabalho.

Ao Conselho Nacional de Pesquisa ( $\mathrm{CNPq}$, pela bolsa de estudos concedida.

Ao Departamento de Genética pelo formecimento da levedura M-300-A utilizada no presente trabalho.

Aos Professores e Funcionários do setor de Bioquímica pelos auxilios prestados, apoio e amizade.

Ao Técnico de Laboratório, Sr. Luiz Lucatti pelo auxílio nas análises químicas e constante apoio e amizade.

Aos Amigos do curso de Pós-Graduação em Microbiologia Agrícola pela amizade.

Aos Amigos Paulo Albuquerque, Fernando Soares e Roberto Moretzon, pela ajuda nas análises estatísticas, apoio e amizade.

E a todos que direta ou indiretamente contribuiram para a execução deste trabalho. 
Página

LISTA DE TABELAS ….......................................................... viii

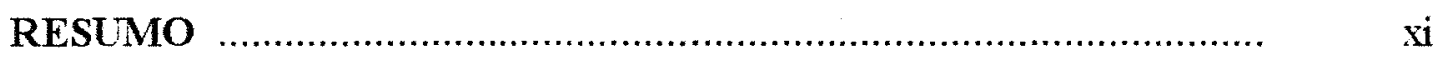

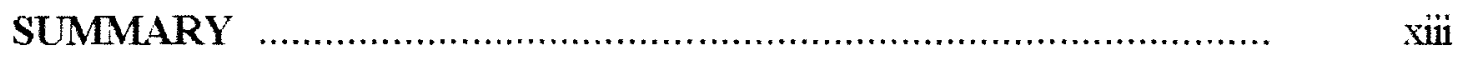

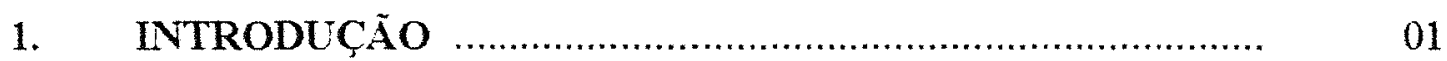

2. REVISÃO DE LITERATURA …......................................... 03

2.1. Termotolerância em Leveduras ........................................ 03

2.2. Tolerância ao Etanol .................................................... 05

2.3. Adaptação dos Microrganismos a Agentes Estressantes ..... 08

2.3.1. Ácidos Graxos ................................................. 08

2.3.2. Acúmulo de Trealose em Microrganismos ............. 11

2.3.2.1. Função …………………….................. 12

2.3.2.2. Localização e Mobilização da Trealose ...... 14

2.3.2.3. Acúmulo de Trealose e Termotolerância .... 15

3. MATERIAL E MÉTODOS …........................................... 17

3.1. Microrganismos ....................................................... 17

3.2. Meio de Crescimento ................................................... 17

3.3. Ensaio 1 - Fermentação com Baixa Concentração de Inóculo e sem Reciclo de Células ................................................. 19

3.3.1. Obtenção do Inóculo ............................................. 19

3.3.2. Meio de Fermentação ........................................... 20

3.3.3. Condução da Fermentação ................................... 20

3.4. Ensaio 2 - Fermentação com Alta Concentração de Inóculo

e Reciclo de Células ....................................................... 21

3.4.1. Obtenção do Inóculo .............................................. 21

3.4.2. Meio de Fermentação ………………………......... 22

3.4.3. Condução da Fermentação …………………........ 
Página

3.5. Análises ….......................................................... 23

3.5.1. Etanol ..................................................... 23

3.5.2. Viabilidade Celular ........................................... 23

3.5.3. Açúcares Redutores .........................................

3.5.4. Glicerol ...................................................... 24

3.5.5. Determinação de Trealose ..................................... 24.

3.5.6. Teor de Matéria Seca …........................................ 24

3.6. Análises Estatísticas ........................................................

4. RESULTADOS E DISCUSSÃO …….................................... 26

4.1. Ensaio sem Reciclo de Células ......................................... 26

4.1.1. Teor de Matéria Seca e Crescimento ...................... 26

4.1.2. Viabilidade Celular e Brotamento .......................... 30

4.1.3. Etanol ......................................................... 35

4.1.4. Trealose ........................................................ 38

4.2. Ensaio com Reciclo de Células ..........................................

4.2.1. Reciclo de Células .............................................. 42

4.2.2. Crescimento Celular após cada Ciclo Fermentativo . 43

4.2.3. Viabilidade Celular e Brotamento ........................... 45

4.2.4. Etanol ....................................................... 50

4.2.5. Glicerol ...................................................... 55

4.2.6. Açúcares Redutores Residuais .............................. 58

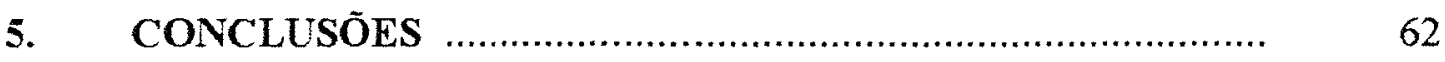

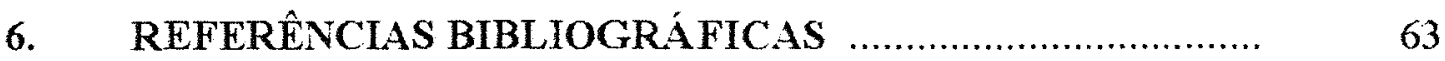

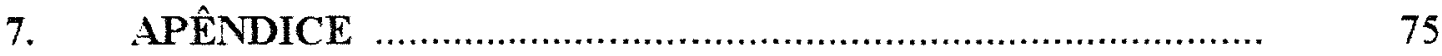




\section{LISTA DE TABELAS}

TABELA

1 Composição química do melaço MB 89/90 utilizado para o meio de crescimento e fermentação $(A R T=65,5 \%, A R=12.6 \%$, $\mathrm{BRIX}=81.5 \%(\mathrm{p} / \mathrm{v})$

2 Teor de matéria seca $(\mathrm{g} / 100 \mathrm{ml})$ de leveduras após fermentação em meio de mosto e melaço com 5 e $12 \%$ de ART, sem reciclo de células. ( $\mathrm{pH} 4.0$, Temperatura $-40^{\circ} \mathrm{C}$ )

3 Biomassa $(\mathrm{g} / 100 \mathrm{ml})$ de leveduras após fermentação em meio de mosto de melaço com 5 e $12 \%$ de ART, sem reciclo de células ( $\mathrm{pH} 4.0$, Temperatura $-40^{\circ} \mathrm{C}$ )

4 Viabilidade celular (\%) de leveduras após fermentação em meio de mosto de melaço com 5 e $12 \%$ de ART, sem reciclo de células, ( $\mathrm{pH} 4.0$, Temperatura $-40^{\circ} \mathrm{C}$ )

$5 \quad$ Brotamento celular (\%) de leveduras após fermentação em meio de mosto de melaço com 5 e $12 \%$ de ART, sem reciclo de células, $\left(\mathrm{pH} 4.0\right.$, Temperatura $-40^{\circ} \mathrm{C}$ )

$6 \quad$ Porcentagem de Etanol (v/v) produzido por leveduras após fermentação em meio de mosto de melaço com 5 e $12 \%$ de ART, sem reciclo de células, ( $\mathrm{pH} 4.0$, Temperatura $-40^{\circ} \mathrm{C}$ )

7 Acúmulo de Trealose ( $\mathrm{g} / 100 \mathrm{~g}$ de biomassa seca) de leveduras após fermentação em meio de mosto de melaço com 5 e $12 \%$ de ART, sem reciclo de células, $\left(\mathrm{pH} 4.0\right.$, Temperatura $\left.-40^{\circ} \mathrm{C}\right)$ 
8 Acompanhamento do peso de fermento úmido $(\mathrm{g} / 100 \mathrm{ml})$ durante os ciclos fermentativos das leveduras $1 Z 888$ e M-300-A, em meio de mosto de melaço com $12 \%$ de ART, reciclo de células, $\left(\mathrm{pH}=4,95\right.$, Temperatura $40^{\circ} \mathrm{C}$ )

9 Acompanhamento do peso de fermento úmido (g/100 ml) durante os ciclos fermentativos das leveduras $\mathrm{ZZ} 888$ e IZ 1904, em meio de mosto de melaço com $12 \%$ de ART, reciclo de células, $\left(\mathrm{pH}=4,95\right.$, Temperatura $\left.-40^{\circ} \mathrm{C}\right)$

10 Viabilidade celular (\%) das leveduras IZ 888 e M-300-A após fermentação em meio de mosto de melaço com $12 \%$ de ART, reciclo de células, $\left(\mathrm{pH}=4,95\right.$, Temperatura $\left.-40^{\circ} \mathrm{C}\right)$

11 Viabilidade celular (\%) das leveduras IZ 1904 e IZ 888 após fermentação em meio de mosto de melaço com $12 \%$ de ART, reciclo de células $\left(\mathrm{pH}=4,95\right.$, Temperatura $\left.-40^{\circ} \mathrm{C}\right)$

12 Brotamento celular (\%) das levecuiras IZ 888 e M-300-A após fermentação em meio de mosto de melaço com $12 \%$ de $A R T$, reciclo de células, $\left(\mathrm{pH}=4,95\right.$, Temperatura $\left.-40^{\circ} \mathrm{C}\right)$

13 Brotamento celular (\%) das leveduras IZ 888 e IZ 1904 após fermentação em meio de mosto de melaço com $12 \%$ de ART, reciclo de células, $\left(\mathrm{pH}=4,95\right.$, Temperatura $-40^{\circ} \mathrm{C}$ )

14 Etanol (\% volume) produzido pelas leveduras M-300-A e IZ 888 em meio de mosto de melaço com $12 \%$ de ART. reciclo de células. $\left(\mathrm{pH}=4,95\right.$, Temperatura $\left.-40^{\circ} \mathrm{C}\right)$ 
TABELA

Página

15 Etanol (\% volume) produzido pelas leveduras IZ 888 e IZ 1904 em meio de mosto de melaço com $12 \%$ de ART, reciclo de células, $\left(\mathrm{pH}=4,95\right.$, Temperatura $\left.-40^{\circ} \mathrm{C}\right)$

16 Glicerol $(\mathrm{g} / 100 \mathrm{ml})$ produzido pelas leveduras M-300-A e IZ 888 após fermentação em meio de mosto de melaço com $12 \%$ de ART, reciclo de células. $\left(\mathrm{pH}=4,95\right.$, Temperatura $\left.-40^{\circ} \mathrm{C}\right)$

17 Glicerol $(\mathrm{g} / 100 \mathrm{ml})$ produzido pelas leveduras IZ 888 e IZ 1904 após fermentação em meio de mosto de melaço com $12 \%$ de ART, reciclo de células, $\left(\mathrm{pH}=4,95\right.$, Temperatura $\left.-40^{\circ} \mathrm{C}\right)$

18 Açúcares redutores residuais ( $\mathrm{g} / 100 \mathrm{ml}$ ) em meio de mosto de melaço com 12\% de ART após fermentação com as leveduras IZ $888 \mathrm{e}$ M-300-A, reciclo de células, $\left(\mathrm{pH}=4,95\right.$, Temperatura $\left.-40^{\circ} \mathrm{C}\right) \ldots$

19 Açúcares redutores residuais $(\mathrm{g} / 100 \mathrm{ml}) \mathrm{em}$ meio de mosto de melaço com $12 \%$ de ART após fermentação pelas leveduras IZ 888 e IZ 1904, reciclo de células, $\left(\mathrm{pH}=4,95\right.$, Temperatura $\left.-40^{\circ} \mathrm{C}\right) \ldots \ldots$. 


\title{
ACUMULO DE TREALOSE EM LINHAGENS DE $S A C C H A R O M Y C E S$ TERMOTOLERANTES
}

\author{
Autor: DENISE APARECIDA DELGADO \\ Orientador: PROF.DR. LUIZ EDUARDO GUTIERREZ
}

\section{RESUMO}

presente trabalho foi realizado com o objetivo de comparar algumas leveduras termotolerantes Saccharomyces cerevisiae (IZ 222, IZ 270, IZ 860, IZ 878, IZ 879, IZ 888, IZ 980, IZ 1256, IZ 1279, IZ 1352, IZ 1831 e IZ 1834) existentes no Departamento de Ciência e Tecnologia Agroindustrial da Escola Superior de Agricultura "Luiz de Queiroz" da Universidade de São Paulo com relação a capacidade fermentativa. viabilidade celular, brotamento, crescimento celular e acúmulo de trealose em condições de fermentação a $40^{\circ} \mathrm{C}$ em duas concentrações de açúcares 5 e $12 \%$ de açúcares redutores totais (ART) e sem reciclo de células. Além disso foi estudada a levedura de melhor desempenho selecionada nesse ensaio com as leveduras utilizadas industrialmente (Saccharomyces cerevisiae IZ 1904 e M-300-A) a $40^{\circ} \mathrm{C}$ e com reciclo de células. Para obtenção do inóculo as leveduras foram multiplicadas anaerobiamente a $33^{\circ} \mathrm{C}$ em mosto de melaço, $\mathrm{pH} 4,0$, contendo $5 \%$ de açúcares redutores totais (ART) suplementado com fosfato dibásico de potássio $(0.5 \mathrm{~g} / 1)$ e sulfato de amônio $(1.0 \mathrm{~g} / 1 \mathrm{e} 1.5 \mathrm{~g} / \mathrm{l})$ nos ensaios com alta e baixa concentração de inóculo. As fermentações foram realizadas com mosto de melaço contendo 5 e $12 \%$ ART suplementadas com sulfato de amônio $(1.0 \mathrm{~g} / 1) \mathrm{e}$ fostato dibásico de potássio $(0.5 \mathrm{~g} / 1)$ para o ensaio sem reciclo de células. Para a comparação das leveduras foi utilizado mosto de melaço com $12 \%$ de ART sem suplementação de sais e sem correção de pH. 
Utilizando-se o mosto com $5 \%$ de ART, as leveduras que apresentaram maior acúmulo de trealose foram a LZ 1831 no primeiro experimento e IZ 888 no segundo experimento. Com o mosto de $12 \%$ de ART não houve diferença significativa entre as leveduras IZ 888 e IZ 1831 quanto ao acúmulo de trealose, crescimento, viabilidade celular. brotamento, produção de etanol, entretanto a IZ 888 apresentou tendência para maior viabilidade celular e brotamento. Nos experimentos realizados em mosto com $5 \%$ de ART não foi possivel relacionar acúmulo de trealose com viabilidade celular, porém em meio com $12 \%$ de ART as leveduras com maior acúmulo de trealose apresentaram maior viabilidade celular. Comparando-se em condições de reciclo de células, a $40^{\circ} \mathrm{C}$, mosto com $12 \%$ de ART a levedura IZ 888 com a IZ 1904 e M-300-A, foi observado um melhor desempenho fermentativo da IZ 888 em relação a IZ 1904 e um pior desempenho em relação a $\mathrm{M}-300-\mathrm{A}$, no que se refere a produções de etanol, glicerol, viabilidade celular e açúcares redutores residuais no meio fermentado. Não se pode afirmar que o acúmulo de trealose seja o único fator para explicar a resistência da levedura as altas temperaturas. 
TREHALOSE ACCUMULATION IN TERMORESISTENT SACCHAROMYCES

Author: DENISE APARECIDA DELGADO

Adviser: PROF. DR. LUTZ EDUARDO GUTIERREZ

\section{SUNMARY}

The actual work aims to compare twelve termoresistent yeasts Saccharomyces cerevisiae (IZ 222, IZ 270, IZ 860, IZ 878, IZ 879, IZ 888, IZ 980, IZ 1256. IZ 1279, IZ 1352, IZ 1831 and IZ 1834) available at the Departamento de Ciência e Tecnologia Agroindustrial da Escola Superior de Agricultura "Luiz de Queiroz" - USP, the comparison work have been carried out relating to fermentating capacity, cell viability, budding, cell growth and accumulation of trehalose under fermentating conditions at $40^{\circ}$ $\mathrm{C}$ and two different sugar concentrations ( 5 and $12 \%$ of total reducing sugars (TRS) without cell recycling.

It has been an aim, avaluate the yeast with the best performance in this assay comparing with industrially utilized yeasts (Saccharomyces cerevisiae IZ 1904 e M300-A) under $40^{\circ} \mathrm{C}$ and with cell recycling. The yeasts have been anaerobically multiplied to obtain the inocule, in must from molasses at $33^{\circ} \mathrm{C}, \mathrm{pH} 4.0$ containing $5 \%$ of total reducing sugar (TRS) supplied with potassium dibasic phosphate $(0.5 \mathrm{~g} / 1)$ and ammonium sulphate $(1.0 \mathrm{~g} / 1$ and $1.5 \mathrm{~g} / 1)$ in the assays with high and low concentration of inocule, respectively. The fermentations have been carried out with must from molasses containing 5 and $12 \%$ of TRS supplied with ammonium sulphate $(1.0 \mathrm{~g} / 1)$ and potassium dibasic phosphate $(0.5 \mathrm{~g} / \mathrm{l})$ in the assay without cell recycling. In order to compare the yeast it has been used the must from molasses with $12 \%$ of TRS without salt suplementation nor $\mathrm{pH}$ correction. 
Under the utilization of $5 \%$ TRS must the yeasts that have showed higher trehalose accumulation have been $L Z 1831$, in the first experiment and $Z 888$ in the second one but there have been no significative difference between IZ 888 and IZ 1831 within $12 \%$ TRS must, without salt suplementation nor $\mathrm{pH}$ correction.

Using the $5 \%$ must, the yeasts that have been showed the highest trehalose accumulation have been IZ 1831 in the first experiment and IZ 888 in the second one. With the $12 \%$ TRS must there was no significative difference between the yeasts IZ 888 and $\mathrm{ZZ} 1831$ in trehalose accumulation, cell growth, viability, budding and ethanol production. In spite of these results, IZ 888 have presented a tendency for higher cell viability and budding. In the experiments carried out with 5\% TRS must it has not been possible to relate trehalose accumulation to cell viability, but in $12 \%$ TRS medium the yeasts with higher trehalose level have showed higher cell viability. In comparision, under cell recycling at $40^{\circ} \mathrm{C}$ and $12 \%$ TRS must, among the yeasts IZ 888, L 1904 and M300-A, it has been observed a better fermentation performance of IZ 888 compared with IZ 1904 and worse performance of it compared with M-300-A, related to ethanol and glicerol production, cell viability and residual reducing sugars in the fermented medium.

It can not be stated that trehalose accumulation in yeasts is the only factor accounting for the yeast resistence to high temperatures. 


\section{INTRODUÇÃO}

As leveduras são os microrganismos mais utilizados industrialmente peio homem na fabricação de álcool, cerveja e pão. Esses microrganismos apresentam um bom desempenho na fermentação de substratos açucarados convertendo-os através da fermentação alcoólica em etanol e dióxido de carbono.

A temperatura ótima para a fermentação alcoólica por leveduras utilizadas em destilarias é de $30^{\circ} \mathrm{C}$. Em regiões tropicais e subtropicais a temperatura do meio de fermentação tende a aumentar até próximo de $40^{\circ} \mathrm{C}$, sendo que essa temperatura pode ser prejudicial para a levedura e consequentemente para o processo fermentativo SAIGAL \& VISWANATHAN (1984).

Com a elevação da temperatura durante o processo fermentativo há necessidade de se ter sistemas para o resfriamento das dornas. Esses sistemas representam gastos adicionais para a indústria. Para minimizar esse problema seria interessante que as leveduras utilizadas durante a fermentação fossem termotolerantes.

A definição de leveduras termotolerantes apresenta uma contradição entre alguns autores; porém segundo SLAPACK et al. (1987) as leveduras termotolerantes são aquelas capazes de crescimento em temperatura igual ou superior a $40^{\circ} \mathrm{C}$.

As leveduras termotolerantes possuem algumas vantagens sobre as mesofilicas como baixo crescimento celular e portanto possuem maior eficiência na fermentação, menor custo de resfriamento das dornas e menor custo de destilação. 
As desvantagens na utilização de leveduras termotolerantes seriam a evaporação do álcool, contaminação e baixa tolerância ao álcool produzido. Com o aumento da temperatura aumenta a intolerância ao etanol (NAVARRO \& DURAND, 1978; GAO \& FLEET, 1988), com isso a maior parte das leveduras termotolerantes apresentam fermentações com baixo grau alcoólico (KAR \& VISWANATHAN, 1985), o que dificulta sua utilizaçào nas destilarias brasileiras que trabalham com grau alcoólico entre 8 e $10 \%(\mathrm{v} / \mathrm{v})$.

As informações disponiveis sobre as características que tornam as leveduras termotolerantes são poucas. $O$ acúmulo de trealose parece contribuir para a proteção das leveduras contra o aumento da temperatura durante o processo fermentativo.

A trealose é um dissacarideo não redutor cuja função por muito tempo foi de carboidrato de reserva, atualmente o mais aceito é que sua função seria de proteção contra o estresse fisiológico.

Dentre as leveduras utilizadas no Brasil para a produção de etanol pela via fermentativa estão Saccharomyces cerevisiae M-300-A e IZ 1904, sendo que algumas informações são conhecidas a respeito do acúmulo de trealose por essas leveduras com os trabalhos de GUTIERREZ (1989) e GUTIERREZ (1990).

A partir dos problemas apresentados nas usinas brasileiras com relação a produção de etanol. seria interessante encontrar uma levedura com elevado teor de trealose, baixa produção de compostos secundários como o glicerol, alta produção de etanol e alta viabilidade celular sendo esse um parâmetro muito importante devido ao sistema de reciclo de células muito utilizado nas usinas brasileiras.

$O$ objetivo do presente trabalho foi o de comparar o desempenho fermentativo de algumas leveduras possivelmente termotolerantes Saccharomyces cerevisiae (IZ 222, IZ 270, IZ 860, IZ 878, IZ 879, IZ 888, IZ 980, IZ 1256, IZ 1279, IZ 1352, IZ 1831, IZ 1834 e IZ 1904) e analisar o acúmulo de trealose por essas leveduras a $40^{\circ} \mathrm{C}$ utilizando duas concentrações de açúcar no meio. E também comparar as leveduras selecionadas no ensaio sem reciclo de células com leveduras industrialmente utilizadas (IZ 1904 e M-300-A) com reciclo de células. 


\section{REVISÃO DA LITERATURA}

\subsection{Termotolerância em Leveduras}

A temperatura é conhecida como sendo uma das variáveis ambientais mais importantes que afeta a atividade dos microrganismos, influenciando o crescimento, metabolismo, viabilidade celular e capacidade fermentativa das leveduras. Cada microrganismo possue uma faixa de temperatura ótima sendo que fora dessa faixa não ocorre crescimento e reprodução.

As leveduras termotolerantes segundo SLAPACK et al. (1987) são aquelas capazes de crescerem em temperatura igual ou superior a $40^{\circ} \mathrm{C}$, elas tem sido isoladas de várias fontes como refinarias de açúcar, rúmen bovino e de amostras de solos tropicais.

ARTHUR \& WATSON (1976) definem a temperatura limite para o crescimento de leveduras psicrófilas, mesófilas, termotolerantes e termófilas como sendo $20,35,42$, e $45^{\circ} \mathrm{C}$, respectivamente.

HACKNG et al. (1984) encontraram 2 linhagens de Kluyveromyces marxianus e Khtyveromyces fragilis como as linhagens mais termotolerantes e capazes de produzir etanol a partir de glucose entre as temperaturas de 37 a $45^{\circ} \mathrm{C}$. SZCZODRAK et al. (1988) também encontraram linhagens de leveduras Fabospora e Kluyveromyces capazes de crescer e fermentar em glucose em temperatura de $46^{\circ} \mathrm{C}$.

IDRIS \& BERRY (1980) utilizaram 12 isolados de levedura para o estudo do efeito do crescimento a 30,35 e $40^{\circ} \mathrm{C}$ sobre os conteúdos de ácido nucleico e proteina. Eles verificaram que a $40^{\circ} \mathrm{C}$ houve redução no conteúdo de proteína e redução dos niveis de ácido nucleico. PARADA \& ACEVEDO (1983) verificaram também que com o aumento da temperatura de 23 para $35^{\circ} \mathrm{C}$ houve uma diminuição no conteúdo de RNA em células de Saccharomyces cerevisiae.

Segundo ARTHUR \& WATSON (1976) a célula de levedura possue uma organização de membrana juntamente com seu rápido crescimento, reprodução e simplicidade genética que a torna um sistema atrativo para o estudo do mecanismo de adaptação térmica em microrganismos eucarióticos. 
SAIGAL \& VISWANATHAN (1984) verificaram que em destilarias. principalmente em regiões tropicais e subtropicais, ocorre uma elevação da temperatura nas domas de fermentação atingindo $40^{\circ} \mathrm{C}$. sendo que muitas vezes a colocação de sistemas de resfriamento não é viável economicamente. A partir desse problema a utilização de leveduras termotolerantes pode representar uma solução viável.

Para aumentar a termotolerância das leveduras alguns estudos tem sido realizados com a suplementação de óleos e ácidos graxos no meio de fermentação. SAIGAL \& VISWANATHAN (1983) verificaram que a adição de alguns óleos e ácidos graxos no meio de fermentação aumentavam a tolerância das leveduras a altas temperaturas.

WATSON (1982) observou que os óleos e ácidos graxos estimularam o crescimento e mantiveram as células ativas, como também protegeram as células da morte térmica a $45^{\circ} \mathrm{C}$, durante 24 horas.

KROWEL \& BRABER (1979) testaram uma linhagem de Saccharomyces cerevisiae e realizaram experimentos elevando a temperatura de 30 para $39^{\circ} \mathrm{C}$ e encontraram que havia diminuição no crescimento e maior produtividade de álcool com o aumento da temperatura, porém em temperaturas acima de $39,6^{\circ} \mathrm{C}$ houve predominância de morte das células.

Segundo NAGODAWITHANA et al. (1974) e NAVARRO \& DURAND (1978), com o aumento da temperatura há aumento na atividade metabólica, com isso a produção de etanol é mais rápida.

Com relação à termotolerância LALUCE et al. (1990) argumentaram que o caráter termotolerância é controlado por fatores genéticos e nutricionais. CASEY et al. (1984) utilizando a levedura de cervejaria Saccharomyces zvarum (carlbergensis) em mostos com alta pressão osmótica e em temperaturas de $14,20,25$ e $30^{\circ} \mathrm{C}$, verificaram que em temperatura mais elevada $\left(30^{\circ} \mathrm{C}\right)$ a levedura apresentava menor viabilidade celular, provavelmente devido a limitação de nutrientes, como o oxigênio e o nitrogênio assimilável. Segundo os autores isso ocorre devido ao aumento do nivel de síntese celular ocorrendo uma fermentação mais rápida. LALUCE et al. (1990) trabalhando com linhagens de leveduras termotolerantes (Saccharomyces) verificaram que houve um aumento da atividade da enzima invertase durante a fermentação em altas temperaturas. Eles encontraram que células com baixa viabilidade celular também possuiam alta atividade da enzima invertase. 
As leveduras podem ser melhoradas atualmente com relação à termotolerância devido à técnicas como a fusão de esferoplasto. PANCHAL et al. (1982) utilizaram uma linhagem de levedura (linhagem 1400), produto da fusão de uma linhagem poliplóide de Saccharomyces cerevisiae com outra diplóide geneticamente construida de Saccharomyces diastaticus. O produto de fusão produzia maior quantidade de etanol. possuindo maior termotolerância e osmotolerância.

O choque térmico é muito utilizado em experimentos para medir a sensibilidade térmica de linhagens, principalmente em estudos genéticos. Esse método consiste na exposição da cultura em temperatura aproximadamente de $52^{\circ} \mathrm{C}$ por poucos segundos, e segundo MC ALISTER \& FINKELSTEN (1980) o choque térmico em leveduras leva à termotolerância.

Segundo SLAPACK et al. (1987) há poucos dados de fermentação por leveduras termotolerantes, não por problemas fisiológicos com a levedura, mas por necessidade de maior exploração da área.

\subsection{Tolerância ao Etanol}

O álcool é o produto principal da glicólise em Saccharomvces cerevisiae e é conhecido por inibir a fermentação e causar outros efeitos desfavoráveis às células de levedura, tais como diminuição na taxa de crescimento e redução na viabilidade celular. Uma das explicações dos efeitos adversos do etanol tem se centralizado na interação deste produto com os lipídios da membrana plasmática (PASCUAL et al., 1987).

A quantidade de etanol produzida no decurso de uma fermentação varia com a linhagem da levedura utilizada. Segundo GRAY (1941) isto se deve em parte a uma maior ou menor resistência ao etanol pelas leveduras. Segundo esse autor a alta ou baixa tolerância ao etanol não é peculiar a qualquer gênero ou espécie de levedura, sendo que dentro de um mesmo gênero ou espécie são encontradas leveduras mais ou menos tolerantes ao etanol. Para BEAVEN et al. (1982) há algumas linhagens de Saccharomyces cerevisiae que são reconhecidas como sendo alguns dos microrganismos eucarióticos mais tolerantes ao etanol. 
No Brasil o etanol representa sem dúvida uma fonte de energia alternativa que atualmente tem sido utilizada com muito sucesso. Alguns trabalhos tem sido realizados visando a melhora da fermentação alcoólica e como consequência a produção de etanol. Para isso tem sido realizada a seleção e $o$ isolamento de leveduras que toleram altas temperaturas e alta concentração de açúcares, como o trabalho realizado por SANTOS (1988).

A produção de etanol é afetada por muitos fatores sendo a temperatura um deles, sendo que há várias referências de leveduras que possuem a habilidade de crescerem em temperatura acima de $40^{\circ} \mathrm{C}$, (STOKES, 1971).

Segundo HUGHES et al. (1984) não há muitos registros de alta produção de álcool por esses microrganismos com capacidade de crescimento em temperaturas acima de $40^{\circ} \mathrm{C}$. Eles isolaram uma linhagem de levedura Kluyveromyces marxianus que possuia a capacidade de fermentar em temperaturas superiores às normaimente encontradas para leveduras. As leveduras foram analisadas entre as temperaturas de $30 \mathrm{e}$ $48^{\circ} \mathrm{C}$ sendo verificado que os efeitos da temperatura elevada foram reduções na biomassa total e na produção de etanol.

D'AMORE \& STEWART (1987) utilizaram linhagens de leveduras Saccharomyces cerevisiae e verificaram que, com o aumento da concentração de carboidratos no meio e consequente aumento da pressão osmótica havia uma elevação na concentração intracelular de etanol no início da fermentação, sendo que após esse periodo a concentração intracelular e extracelular se igualavam. Para HOPPE \& HANSFORD (1982) o álcool tem uma ação inibitória maior para a levedura quando gerado endogenamente do que quando adicionado externamente.

BROWN \& OLIVER (1982) utilizando Saccharomyces uvarum encontraram que o efeito inibitório do etanol foi diferente durante o estágio de crescimento e fermentação das leveduras. Nesse experimento o etanol foi adicionado exogenamente ao meio de cultura. Eles encontraram que a levedura foi mais resistente à inibição pelo etanol 5 e $10^{\circ} \mathrm{C}$ abaixo do seu ótimo de crescimento $\left(35^{\circ} \mathrm{C}\right)$. O resultado obtido para a fermentação foi de que quanto maior a temperatura mais resistente a levedura era com relação à inibição pelo etanol. Para NAVARRO \& DURAND (1978) quanto maior a temperatura da fermentação maior é o efeito inibitório do etanol, tanto endógeno quanto exógeno. Segundo NOVAK et al. (1981) a taxa de excreção de álcool da célula para o meio é menor do que o acúmulo de álcool que ocorre endógenamente. 
NGRAM (1976) estudou o efeito do etanol em celulas de Escherichia coli com relação a alteração que este causa na membrana das células. Ele inferiu que o etanol e outros álcoois de cadeia curta se inserem no interior hidrofóbico da bicamada lipidica restringindo a movimentação das cadeias de ácidos graxos ou preenchendo os espaços causados pelos ácidos graxos insaturados, agem assim diminuindo a fluidez da membrana.

WATSON \& CAVICHIOLI (1983) verificaram que as leveduras Saccharomyces cerevisiae e Saccharomyces saké, adquiriram tolerância ao etanol quando crescidas a $37^{\circ} \mathrm{C}$ e submetidas ao choque térmico de $52^{\circ} \mathrm{C}$ por 5 minutos ou crescidas em uma temperatura de $23^{\circ} \mathrm{C}$ e com choque térmico de $37^{\circ} \mathrm{C}$ por 30 minutos. Os autores concluiram que há produção de proteínas de choque térmico e que existe uma relação causal entre a sintese dessas proteínas e a sobrevivência das células submetidas ao choyiue térmico.

A produção de etanol pode ser aumentada de vários modos sendo que algumas alternativas foram testadas como é o caso da adição de óleos vegetais (SAIGAL \& VISWANATHAN, 1983), adição de sais de magnésio (DOMBEK \& INGRAM, 1986), óleo de soja (ALTERTHUM \& CRUZ, 1987), adição de cálcio (NABAIS et al., 1988) e ácidos graxos (GUTIERREZ, 1991). Com esses suplementos há uma melhora com relação à tolerância das leveduras ao etanol durante a fermentação alcoólica.

WATSON (1982) utilizando linhagens de Saccharomyces verificou que, células com baixo conteúdo de ergosterol na membrana quando colocadas em meio suplementado com ácido oleico ocorria um aumento na concentraçào de etanol produzido.

ROMAY et al. (1988) trabalharam com linhagens de Saccharomyces cerevisiae para observar o efeito do etanol adicionado ao meio com relação ao transporte de glucose e fluxo de prótons através da membrana. Eles encontraram que, com adição de altas concentrações de etanol ( $3 \mathrm{M}$ ) o fluxo de prótons foi o mais atingido, podendo ser o primeiro local de ação do álcool na fermentação. Esse experimento também mostrou que as enzimas glicolíticas foram muito afetadas com o aumento da concentração de etanol, com exceção da fosfofrutoquinase. $O$ transporte de glucose não foi afetado nesse experimento, não sendo o responsável pela redução da fermentação em quase $50 \%$ após adição do etanol. 


\subsection{Adaptação dos Microrganismos a Agentes Estressantes}

Os microrganismos possuem uma capacidade de se adaptarem às condições desfavoráveis impostas pelo ambiente como temperatura, desidratação, quantidade de etanol presente no meio e muitos outros agentes que provocam o estresse.

Para a adaptação dos microrganismos a essas condições são necessários mecanismos como o acúmulo de carboidrato como a trealose, que funciona como um carboidrato de proteção ao estresse (THEVELEN, 1984; HOTTIGER et al, 1987a,b; P.ANEK et al.. 1990), e a alteração da composição em ácidos graxos na membrana citoplasmática (ARTHUR \& WATSON, 1976; SAJBIDOR \& GREGO, 1992).

\subsection{1. Ácidos Graxos}

Os ácidos graxos possuem uma função importante na determinação das propriedades tísico-químicas dos lipídios de membrana (SUUTARI et al., 1990).

Com o trabalho de ANDREANSEN \& STIER (1954) foi encontrado que as leveduras Saccharomyces exigem a presença de ácidos graxos insaturados e ergosterol para a multiplicação em meio anaeróbico. BLOOMFIELD \& BLOCK (1960) verificaram que a dessaturação de ácidos graxos exige a presença de oxigênio molecular que não pode ser substituído por outros aceptores de elétrons.

WILSON \& MCLEOD (1976) estudaram leveduras e verificaram que a perda de viabilidade ocorrida durante o jejum não foi devido a deficiência de reservas endógenas e sim devido a alterações das funções das membranas devido à deficiência de esteróides e ácidos graxos insaturados.

De acordo com QUASTEL (1967) os ácidos graxos presentes na membrana celular podem ser insaturados ou saturados, porém, a proporção ideal que representa a estabilidade e porosidade para a bicamada de lipídios da membrana é dois ácidos graxos insaturados para um saturado.

ARTHUR \& WATSON (1976) relataram que as propriedades das membranas biológicas são fundamentais para a habilidade dos microrganismos crescerem e se reproduzirem em meio com diferentes temperaturas. 
Para FARRELL \& ROSE (1967) a composição lipidica da membrana de leveduras varia com relação à temperatura. Para BROWN \& ROSE (1969.) a composição em ácidos graxos dos microrganismos varia em relação, além da temperatura. com a especie do microrganismo, a idade da cultura e a composição do meio de cultura.

Foi verificado por ALTHERTHLM \& CRUZ (1987) que em temperaturas elevadas há uma predominância de ácidos graxos com cadeias longas e saturadas, em baixas temperaturas há um aumento no grau de insaturação da cadeia carbônica e diminuição da mesma.

SUUTARI et al. (1990) utilizando alguns gêneros de leveduras encontraram que elas mostravam respostas diferentes na composição em ácidos graxos. com relação à adaptação das mesmas durante a alteração de temperatura. Saccharomyces cerevisiae alterou o comprimento da cadeia de ácidos graxos quando houve alteração da temperatura, porém não apresentou variação no grau de insaturação com o aumento da temperatura o que foi sugerido também por HUNTER \& ROSE (1972).

Ainda com relação a alteração na composição em ácidos graxos com a mudança de temperatura, GILL \& SUISTED (1978) encontraram que em bactérias de vários gêneros havia uma variação no conteúdo de ácidos graxos insaturados em todas as espécies, quando a temperatura era alterada acima ou abaixo do seu ótimo de crescimento, porém cada gênero apresentou um comportamento diferente quando a temperatura era diminuida quase pela metade do ótimo de crescimento.

LOW \& PARKS (1987) trabalharam com Saccharomyces cerevisiae e encontraram que com o aumento da temperatura de crescimento havia um aumento no conteúdo de ácidos graxos saturados (16:0 e 18:0) enquanto que havia uma diminuição dos ácidos graxos insaturados (16:1 e 18:1). As leveduras foram testadas em uma faixa de temperatura de $24-40^{\circ} \mathrm{C}$.

A levedura Saccharomyces cerevisiae, segundo WATSON (1987), possue somente resíduos de ácidos graxos monoinsaturados e não faz alteração na insaturação dos lipídios quando ocorre alteração na temperatura de crescimento.

Segundo RATTRAY et al. (1975) a composição em ácidos graxos dos lipídios de levedura mostram uma preponderância de ácidos graxos com 16 e 18 carbonos.

A composição em ácidos graxos da membrana citoplasmática varia entre as leveduras e tem sido utilizada para a classificação. Com esse método é possível diferenciar 
as leveduras em espécies e algumas vezes ao nivel de linhagem (OOSTHULEN et al.; 1987; BENDOVÁ et al.: 1991).

Tem sido verificado por alguns autores que a adição de suplementos ao meio pode proteger as células contra o estresse térmico e o provocado por altas concentrações de etanol.

GUTIERREZ (1991) trabalhando com leveduras de panificaçào obteve que a adição de ácido linoleico ao meio é benéfica para a proteção de células contra o estresse térmico. Nesse estudo foi verificado aumento da viabilidade celular com adição do ácido nas temperaturas de 30 e $35^{\circ} \mathrm{C}$.

SAIGAL \& VISWANATHAN (1983, 1984) utilizando a levedura Saccharomyces cerevisiae verificaram que a eficiência fermentativa e a tolerância ao etanol era melhorada com a suplementação do meio com óleos e ácidos graxos em fermentação a 30 e $40^{\circ} \mathrm{C}$. Em fermentação a $40^{\circ} \mathrm{C}$ foi verificado que os ácidos graxos ofereciam proteção contra a inativação pelo calor. Os autores concluíram que a suplementação com óleos e ácidos graxos provavelmente alteram a estrutura da membrana citoplasmática reduzindo os efeitos prejudiciais das altas temperaturas.

THOMAS et al. $(1978,1979)$ encontraram que populações de células de Saccharomyces cerevisiae enriquecidas com resíduos de ácido graxo linoleico permaneciam viáveis por mais tempo que as células enriquecidas com resíduos de ácido graxo oleico quando em presença de $1 \mathrm{M}$ de etanol. Segundo esses autores a tolerância da levedura ao etanol está intimamente ligada à composição química dos lipídios da membrana plasmática, sendo que entre os vários componentes os lipídios são os principais sítios de toxicidade do etanol.

As células alteram a composição em ácidos graxos quando em altas temperaturas e também em presença de etanol (MISHRA \& PRASAD, 1989). Esses autores verificaram ainda que células de Saccharomyces cerevisiae quando eram enriquecidas com ácidos graxos poliinsaturados adquiriam maior tolerância ao etanol (2M) adicionado exogenamente, do que as enriquecidas com ácidos graxos monoinsaturados.

LEGMANN \& MARGALITH (1987) compararam duas espécies da levedura Saccharomyces, uma com boa capacidade fermentativa e a outra com baixa capacidade fermentativa, eles verificaram que a levedura Saccharomyces cerevisiae altamente fermentativa não apresentava ácidos graxos polinsaturados como linoleico e linolênico, mas possuiam um nivel mais elevado de ácidos graxos saturados e esteróis livres. 
SAJBIDOR \& GREGO (1992) encontraram que células de leveduras Saccharomyces cerevisiae expostas ao etanol, em condições estressantes, faziam uma reestruturação da membrana, com redistribuição dos ácidos graxos nos lipídios estruturais.

\subsubsection{Acúmulo de Trealose em Microrganismos}

A trealose é um dissacarídeo não redutor ( $\alpha-D$-glucopiranosil (1-1) $\alpha-D-$ glucopiranosídeo). Este carboidrato está presente em uma grande quantidade de organismos como procariotos, plantas, animais, sendo largamente distribuido entre os fungos onde pode ser encontrado nos estágios vegetativos e reprodutivos (ELBEIN, 1974).

A trealose foi primeiramente isolada da ferrugem do centeio por WIGGERS em 1832 e foi extraída pela primeira vez de células de levedura em 1925 por KOCK \& KOCK. Segundo THEVELEIN (1984) a trealose está localizada no citossol da célula.

PANEK et al. (1990) verificaram que células de Saccharomyces cerevisiae são capazes de acumular dois carboidratos quando colocadas em condições especiais: a trealose e o glicogênio. Estes dissacarídeos possuem uma função muito importante na manutenção, diferenciação e sobrevivência das leveduras.

Segundo PANEK (1975) utilizando leveduras de panificação encontrou que o glicogênio năo contribue para a síntese de trealose. Para CROWE et al. (1986) o glicogênio poderia ser transformado sob algumas condições em trealose e vice-versa.

THEVELEN (1984) encontrou em seu trabalho que o acúmulo de trealose em fungos estava associada em geral com períodos de reduzida taxa de crescimento. A sintese do carboidrato segundo o autor é mais intensa durante os processos de diferenciação e períodos de deficiência de nutrientes.

Para KELLER et al. (1982) a trealose e o glicogênio podem ser acumulados pelas células em quantidades semelhantes, porém o que difere é o modo de acúmulo e de utilização desses carboidratos.

Com relação às condições de formação da trealose, GRBA et al. (1975) encontraram em levedura de panificação que a formação desse carboidrato foi mais rápida em condições aeróbias do que em condições anaeróbias, tanto utilizando glucose ou maltose como substrato. 


\subsubsection{Função}

Há muita contradição entre os vários autores com relação a função da trealose sendo que originalmente em leveduras esse carboidrato parece ter uma função de reserva energética juntamente com o glicogênio. Ultimamente muitos estudos tem mostrado que a trealose possue uma função de proteção em células de levedura durante processos de estresse.

De acordo com o Dicionário Inglês Oxford, reserva é alguma coisa estocada para ser utilizada no futuro, porém, é questionado qual seria o uso e função da presença de dois carboidratos de reserva (trealose e glicogênio) em um mesmo organismo (PANEK. 1991).

Segundo LILLE \& PRINGLE (1980) para que um composto seja considerado de reserva ele deve ser acumulado quando as fontes externas (carbono, nutrientes e outras) são abundantes com o intuito de servir como substrato em periodos desfavoráveis. A trealose possue um comportamento diferente, ou seja, só é acumulada pela célula após a exaustão da glucose no meio durante a fase lag de diauxia.

O fato que a trealose é somente acumulada quando a glucose exógena é quase exaurida, atingindo alta concentração dentro da célula durante a limitação de glucose e nutrientes, sugere que a trealose sintetase pode ser mais ativa em baixas concentrações de glucose-6-fosfato (PANEK, 1975).

GRBA et al. (1975) utilizando levedura de panificação encontraram que a formação de trealose depende da quantidade de glucose presente no meio, sendo que quando termina a glucose cessa a produção de trealose.

WIENKEN (1990) concluiu que a função primária da trealose é de proteção dos componentes do citossol contra condições desfavoráveis. A função da trealose em esporos de leveduras em dormência segundo BARTON et al. (1982) poderia ser de suprimento de energia. Eles utilizaram a levedura Pichia pastoris e verificaram que a trealose era utilizada como uma fonte de carboidrato para a formação de ATP nessas condições.

Os esporos são estruturas muitos resistentes ao calor, frio e desidratação. Para THEVELEIN (1984) a trealose teria a função de carboidrato de proteção nestas estruturas, também foi verificado que com a germinação do esporo a trealose é rapidamente consumida. 
O glicogênio segundo LILLE \& PRINGLE (1980) possue um comportamento típico de composto de reserva. Apesar de possuírem padrões de acumulação diferentes esses autores consideram a trealose e o glicogênio como carboidratos de reserva.

SUOMALAINEN \& PFAFFLI (1961) trabalhando com levêdo de panificação verificaram que a melhora da viabilidade celular e da atividade da levedura era devido ao elevado teor de trealose. Nesse caso a trealose teria a função de proteger as células contra a autólise.

A temperatura para o acúmulo de trealose segundo GRBA et al. (1975) em leveduras de panificação (Saccharomyces cerevisiae) foi de $45^{\circ} \mathrm{C}$ e para a formação do glicogênio a temperatura encontrada foi de $30^{\circ} \mathrm{C}$. Segundo os autores é importante selecionar uma temperatura de incubação na qual se obtenha uma levedura com alto acúmulo de trealose (20\%) sendo essas muito resistentes à desidratação, sendo assim estas leveduras poderiam ser utilizadas para o preparo de levedura desidratada ativa.

Com relação aos agentes estressantes que provocam acúmulo de trealose ATTFIELD (1987) verificou que havia acúmulo do carboidrato quando as células eram expostas ao etanol, sulfato de cobre ou peróxido de hidrogênio a $30^{\circ} \mathrm{C}$, indicando que esse acúmulo poderia ser uma resposta geral das células a qualquer tipo de estresse fisiológico.

A velocidade de fermentação durante o processo fermentativo sofre influência de diversos fatores dentre eles estão a viabilidade celular, a temperatura de fermentação, pressão osmótica, o tipo de açúcar presente no meio e o efeito de altas concentrações de álcool presente no meio. A trealose parece ter a função de proteção contra os efeitos desses fatores de estresse, melhorando as condições das células e com isso seu desempenho durante a fermentação.

D'AMORE et al. (1991) examinaram 12 cepas de leveduras de várias espécies com relação a capacidade destas células produzirem etanol a partir de concentrações elevadas de glucose. Eles encontraram que as células produtoras de quantidades mais elevadas de etanol possuíam concentrações iniciais mais altas de trealose, possuindo maiores viabilidades celulares quando estocadas em baixas temperaturas $\left(-20^{\circ}\right.$ C) ou em vinho com $5 \%(\mathrm{v} / \mathrm{v})$ de etanol a $4^{\circ} \mathrm{C}$ durante 30 dias. Com esses resultados é possivel visualizar a importância da obtenção de leveduras com maior quantidade de trealose o que seria importante para melhorar o desempenho das leveduras durante 0 processo fermentativo. 
Os organismos anidrobióticos possuem a capacidade de viver muito tempo no estado de desidratação sendo metabolicamente inertes e muito resistentes a condições ambientais como seca, calor e frio (WIENKEN, 1990). CROWE et al (1984a) verificaram que grande quantidade de trealose é encontrada nesses organismos (até $20 \%$ do seu peso seco).

Há alguns modelos que procuram explicar o efeito de proteção da trealose na membrana plasmática das células durante os processos de desidratação/hidratação e congelamento/descongelamento. $\mathrm{O}$ modelo atualmente mais aceito é o de que a trealose interage com os grupos polares das cadeias fosfolipidicas existentes na membrana. A trealose segundo o modelo proposto por CROWE et al. (1984b) substituiria a água que está ligada nas cabeças polares dos fosfolipídios quando em condições favoráveis e é perdida nos processos de estresse. Com a ligação da trealose à membrana não há alteração do espaçamento entre os fosfolipídios, evitando assim as separações laterais de fase dos componentes da membrana. Deste modo, com a substituição das moléculas de água pela trealose não há passagem da fase fluida para a fase gel da membrana, sendo com isso mantida a integridade e fluidez das membranas, aumentando a viabilidade das células.

\subsubsection{Localização e Mobilização da Trealose}

Segundo PANEK et al (1986), a única enzima conhecida como responsável pela degradação da trealose em Saccharomyces é a trealase. KELLER et al. (1982) utilizando uma linhagem diplóide de Saccharomyces cerevisiae demonstraram que a trealase estava localizada em vacúolos e a trealose no citossol.

Com relação à substituição das moléculas de água por trealose durante a desidratação foi verificado por CROWE et al (1991) que a levedura Saccharomyces cerevisiae possue um transportador para a trealose. ELEUTHERIO et al. (1993)

utilizando células de Saccharomyces cerevisiae encontraram que a trealose deve estar presente nos dois lados da bicamada de lipídios para oferecer proteção contra o estresse. Foi encontrado pelos autores que para a presença da trealose nos dois lados da membrana havia necessidade de um carregador já que é conhecido que esse carboidrato é produzido no citossol da célula. Foi observado nesse trabalho que mutantes que não possuíam o carregador apesar de acumularem trealose possuíam baixa sobrevivência à desidratação. 


\subsubsection{Acúmulo de Trealose e Termotolerância}

FEOFILOVA et al. (1989) não encontraram efeito termoprotetor da trealose em fungos termofilicos.

HOTTIGER et al. (1987a) e HOTTIGER et al (1987b) trabalhando com Saccharomyces cerevisiae encontraram que com a elevação da temperatura de $27^{\circ} \mathrm{C}$ para $40^{\circ} \mathrm{C}$ havia um aumento no acúmulo de trealose sendo que com a transferência das células novamente para $27^{\circ} \mathrm{C}$ havia uma diminuição no nível de trealose. HOTTIGER et al. (1987b) utilizando a mesma levedura encontraram que com a elevação da temperatura de $27^{\circ} \mathrm{C}$ para $40^{\circ} \mathrm{C}$ havia um aumento de seis vezes na atividade da enzima responsável pela biossintese da trealose, a trealose fosfato sintase.

HOTTIGER et al. $(1987 \mathrm{a}, \mathrm{b})$ concluiram que o acúmulo de trealose ocorrido quando as células de Saccharomyces cerevisise eram submetidas à temperaturas superiores à normal de crescimento, estava relacionado com a aquisição de termotolerância.

PANEK et al. (1990) trabalharam com linhagens de Saccharomyces controles e mutantes, sendo que uma delas ( $\mathrm{klg} 102$ ) não produzia trealose. Nesse experimento as células cresceram em temperaturas de $23^{\circ} \mathrm{C}$, sendo submetidas a um estresse térmico ( $36^{\circ} \mathrm{C}$ por 90 minutos) e logo após submetidas a um choque térmico $\left(52^{\circ} \mathrm{C}\right.$ por 2 minutos). Foi encontrado que o mutante que acumulava maior quantidade de trealose foi o mais resistente ao choque térmico, entretanto, o mutante que não acumulava trealose (klg 102) mostrou boa resistència ao choque térmico podendo ser comparado ao desempenho dos controles. Foi concluído pelos autores que a sobrevivência das células ao choque térmico não está exclusivamente correlacionado com o acúmulo de trealose ou com a síntese de proteínas de choque térmico.

A composição em ácidos graxos das membranas poderia ser um fator relacionado à menor ou maior tolerância das células as altas temperaturas e outros fatores estressantes.

DE VIRGILIO et al. (1991) estudaram a aquisição de termotolerância em mutantes de Saccharomyces cerevisiae sendo as linhagens submetidas a um pré tratamento térmico a $40^{\circ} \mathrm{C}$ e depois a um estresse térmico a $50,4^{\circ} \mathrm{C}$. Eles encontraram que o mutante que não produzia proteina de choque térmico (HSP) adquiriram termotolerância embora em menor escala que a linhagem selvagem. Esses resultados mostraram que a aquisição de termotolerância e o acúmulo de trealose estão estreitamente 
correlacionados durante o pré tratamento a $40^{\circ} \mathrm{C}$ e são modulados pela síntese de proteína mas não requerem essa síntese.

Ainda com relação à termotolerância, acúmulo de trealose e síntese de proteina de choque térmico, WIENKLER et al. (1991) encontraram que mutantes de Saccharomyces cerevisiae (HSP 104) que não produziam proteína de choque térmico, mas acumulavam trealose, foram mais sensíveis que as linhagens selvagens quando submetidos ao choque térmico a $50^{\circ} \mathrm{C}$ durante 20 minutos. Com isso os autores concluíram que a proteína de choque térmico é que protegia as células de Saccharomyces submetidas ao choque térmico e não o acúmulo de trealose. 


\section{MATERIAL E MÉTODOS}

No presente trabalho foram realizados 2 ensaios de fermentaçăo sendo um com baixa concentração de inóculo e sem reciclo de células e o outro com alta concentração de inóculo e com reciclo de células.

\subsection{Microrganismos}

As leveduras utilizadas nos ensaios foram as linhagens de Saccharomyces cerevisiae (IZ 270, IZ 222, IZ 860, IZ 878, IZ 879, IZ 888, IZ 980, IZ 1256, IZ 1279, IZ 1352, IZ 1831, IZ 1834, IZ 1904). Foram testadas inicialmente 50 linhagens de leveduras e selecionadas 13 para a utilização no presente trabalho, com base no crescimento a $40^{\circ} \mathrm{C}$ por 48 horas em tubos de ensaio contendo meio de extrato de malte. As leveduras foram fornecidas pelo Departamento de Ciência e Tecnologia Agroindustrial da Escola Superior de Agronomia "Luiz de Queiroz" da USP.

Nos ensaios realizados foi utilizada também a levedura M-300-A (híbrido entre as linhagens IZ 671 e IZ 672 de Saccharomyces cerevisiae) obtida junto ao Departamento de Genetica da Escola Superior de Agricultura "Luiz de Queiroz" da USP.

\subsection{Meio de Crescimento}

O melaço utilizado para a preparação dos meios nesse trabalho foi proveniente da Usina Maurilio Biaggi (MB), Ribeirão Preto, SP, da safra de 1989/1990. Os teores minerais (ppm) do melaço se encontram na tabela 1. 
As leveduras utilizadas na fermentação foram multiplicadas em laboratório em meio de melaço a 5\% de Açúcares Redutores Totais (ART), com suplementação de fosfato dibásico de potássio $(0.5 \mathrm{~g} / \mathrm{l})$ e sulfato de amonio $1.0 \mathrm{~g} / \mathrm{e} 1.5 \mathrm{~g} / \mathrm{l}$, nos ensaios com baixa e aita concentração de inóculo, respectivamente.

$\mathrm{O}$ pH do meio foi corrigido para $4,0 \mathrm{com}$ a utilização de $\mathrm{H}_{2} \mathrm{SO}_{4} 2 \mathrm{~N}$. O meio foi colocado em erlenmeyers e esterilizado em autoclave a $121^{\circ} \mathrm{C}$ durante 15 minutos.

Tabela 1. Composição química do melaço MB $89 / 90$ com $65.5 \%$ de ART, $12,6 \%$ de AR e BRLX de $81.5(\mathrm{~g} / 100 \mathrm{ml})$, utilizado para o meio de crescimento e fermentação.

\begin{tabular}{|c|c|}
\hline $\mathrm{SO}_{2}$ & 9 \\
\hline $\mathrm{Ca}$ & 1.840 \\
\hline $\mathrm{Mg}$ & 1.750 \\
\hline $\mathrm{K}$ & 17.600 \\
\hline $\mathrm{N}$ & 4.200 \\
\hline $\mathrm{P}$ & 294 \\
\hline $\mathrm{Zn}$ & 85 \\
\hline $\mathrm{Mn}$ & 13 \\
\hline $\mathrm{Fe}$ & 161 \\
\hline $\mathrm{Cu}$ & 10,5 \\
\hline
\end{tabular}


3.3. Ensaio 1 - Fermentação Com Baixa Concentração de Inóculo e Sem Reciclo de Células

Vesse ensaio foram realizados quatro experimentos sendo que para cada um deles foi feita a multiplicação das leveduras e fermentaçào. $O$ conjunto de leveduras testadas foi diferente para cada experimento.

Experimento 1: Leveduras IZ 222, IZ 270, IZ 1831, IZ 1834

Experimento 2: Leveduras IZ 888, IZ 860. IZ 878, IZ 980

Experimento 3: Leveduras IZ 1256, IZ 1279, IZ 1352, IZ 1831, IZ 1904

As leveduras que obtiveram melhor desempenho fermentativo nos experimentos acima foram escolhidas para o experimento 4.

Experimento 4: Leveduras IZ 860, IZ 888, IZ 1279, IZ 1831. IZ 1904

\subsubsection{0btenção do Inóculo}

As leveduras foram inoculadas em condições assépticas inicialmente em erlenmeyers de $125 \mathrm{ml}$ contendo $50 \mathrm{ml}$ de meio de crescimento e levadas para estufa a $33^{\circ} \mathrm{C}$ por 24 horas. Após ter sido completado esse tempo o inóculo foi transferido para erlenmeyers de $500 \mathrm{ml}$ contendo $200 \mathrm{ml}$ de meio de crescimento e novamente mantidos em estufa a $33^{\circ} \mathrm{C}$ por mais 24 horas. Após o crescimento da levedura os frascos foram retirados da estufa e levados à geladeira para decantação por 24 horas. Após esse periodo, o sobrenadante foi descartado e foi feita a lavagem do precipitado de células, utilizando água destilada, sendo os frascos levados novamente para decantação. 
Após o sobrenadante ter sido descartado o precipitado de células foi ressuspenso em balão volumétrico de $100 \mathrm{~m}$ com água destilada. Foi retirado $5 \mathrm{ml}$ da suspensão sendo esse volume transferido para tubos de ensaio previamente tarados para obtenção do teor de materia seca.

A partir da obtenção do teor de matéria seca em $5 \mathrm{ml}$ foi feito o cálculo do volume que deveria ser inoculado nos frascos de fermentaçào, esse volume deveria conter aproximadamente $30 \mathrm{mg}$ de leveduras com base na matéria seca.

\subsubsection{Meio de Fermentação}

$O$ meio utilizado para a fermentação nos 3 primeiros experimentos foi um meio de melaço a $5 \%$ de ART com suplementação de sais, o mesmo utilizado para o crescimento. No quarto experimento o meio de fermentação foi constituído de $12 \%$ de ART com suplementação de sulfato de amônio $(1,0 \mathrm{~g} / 1)$ e fosfato de potássio $(0,5 \mathrm{~g} 1)$.

\subsubsection{Condução da Fermentação}

Para a fermentação foram utilizados frascos de gargalo estreito com $120 \mathrm{ml}$ de capacidade, onde foram colocados $50 \mathrm{ml}$ de meio de mosto de melaço a $5 \%$ de ART (experimentos 1, 2 e 3 ) e $12 \%$ de ART (experimento 4). Os frascos foram fechados com papel alumínio e esterilizados em autoclave a $121^{\circ} \mathrm{C}$ por 15 minutos. As leveduras foram inoculadas assepticamente, correspondendo a $30 \mathrm{mg}$ de levedura com base na matéria seca.

Após a inoculação das leveduras, os frascos foram incubados em estufa em temperatura de $40^{\circ} \mathrm{C}$. Para acompanhar a liberação de $\mathrm{CO}_{2}$ e o final da fermentação foram realizadas pesagens sucessivas até o término da fermentação. 
Nesse ensaio foram utilizadas 4 repetiçôes para cada linhagem de levedura na multiplicação e fermentação exceto para o experimento 2 onde foram utilizadas 3 repetições para a fermentação.

Foram realizadas nesse ensaio análises do teor de matéria seca, determinação de etanol, viabilidade celular, brotamento e teor de trealose.

\subsection{Ensaio 2 - Fermentação Com Alta Concentração de Inóculo e Reciclo} de Células

Para esse ensaio foram realizados 2 experimentos:

Experimento 1: As leveduras utilizadas foram $\mathrm{IZ} 888 \mathrm{e} \mathrm{IZ} \mathrm{1904.} \mathrm{Foram} \mathrm{realizados} 4$ reciclos de células.

Experimento 2: As leveduras utilizadas foram IZ 888 e M-300-A. Foram realizados 5 reciclos de células.

A levedura IZ 888 foi escolhida em função dos resultados dos experimentos anteriores. As leveduras IZ 1904 e M-300-A devido a sua utilização em destilarias.

\subsubsection{Obtenção do Inóculo}

As leveduras foram multiplicadas em meio de mosto de melaço a $5 \%$ de ART com suplementação dos sais sulfato de amônio $(1.0 \mathrm{~g} / 1)$ e fosfato dibásico de potássio $(0.5 \mathrm{~g} 1)$. Inicialmente as leveduras foram inoculadas em frascos com capacidade 
de 3 litros contendo 2 litros de meio. Os frascos foram levados à estufa a $33^{\circ} \mathrm{C}$ por um periodo de 36 horas (final da fermentação).

Em seguida os frascos foram levados à geladeira para decantação por 24 horas, sendo o sobrenadante descartado após esse periodo.

O precipitado de células foi ressuspenso em $500 \mathrm{ml}$ de água destilada e deixado decantar em geladeira por mais 24 horas. Após esse tempo o sobrenadante foi descartado e o precipitado de células ressuspenso em $200 \mathrm{ml}$ de água destilada e a suspensão resultante utilizada como inóculo de leveduras.

\subsubsection{Meio de Fermentação}

$O$ meio de melaço utilizado para a fermentação foi constituido de $12 \%$ de ART sem suplementação de sais e sem esterilização. Para obtenção do meio com 12\% de ART foi pesado 370 gramas de melaço e diluído em $2000 \mathrm{ml}$ de água destilada. $O$ mosto obtido do melaço apresentou $\mathrm{pH} 4,95$ e não foi corrigido.

\subsubsection{Condução da Fermentação}

Para cada linhagem de levedura foram utilizados 3 tubos de fermentação previamente tarados, contendo aproximadamente 7 gramas de fermento úmido onde foi adicionado $50 \mathrm{ml}$ de meio de fermentação. A fermentação foi conduzida em estufa a $40^{\circ}$ $C$ sendo realizadas pesagens periódicas para acompanhamento da liberação de $\mathrm{CO}_{2}$ como realizado no ensaio sem reciclo de células no item 3.3.3. Após o término da fermentação os tubos foram agitados e foi retirada uma amostra de $0,5 \mathrm{ml}$ para análise de viabilidade celular e brotamento.

Após a coleta da amostra os tubos foram centrifugados a $1500 \mathrm{rpm}(800$ $G)$ por 15 minutos. $O$ sobrenadante foi utilizado para as determinações analíticas de 
Açucares Redutores (AR), Glicerol e Etanol. $O$ fomento foi reutilizado para o ciclo seguinte.

\subsection{Análises}

\subsubsection{Etanol}

Para a determinação de etanol foi utilizado $25 \mathrm{ml}$ do meio fermentado que foi destilado em microdestilador Kjeldall adaptado para álcool. $O$ destilado obtido foi utilizado para a medida de densidade em densímetro digital Anton - Paar modelo DMA 46, segundo AMORIM et al. (1982).

\subsubsection{Viabilidade Celular}

A contagem de viabilidade celular foi obtida utilizando azul de metileno segundo PIERCE (1970) e descrito por DE MARTIN (1987).

\subsubsection{Açúcares Redutores}

Os teores de açúcares redutores foram obtidos pelo método de Somogyi e Nelson adaptado por AMORM et al. (1982). 


\subsubsection{Glicerol}

O teor de glicerol foi dosado no mosto fermentado, utilizando o método colorimétrico de oxidação com metaperiodato seguido de reação do formaideido formado com acetil-acetona e amônia segundo ZAGO et al. (1989).

\subsubsection{Determinação de Trealose}

A análise do teor de trealose foi feita através de extração com ácido tricloroacético (TCA) a frio segundo TREVELYAN \& HARRISON (1956) e determinação pelo método da antrona segundo BRN (1966).

\subsubsection{Teor de Matéria Seca}

$5 \mathrm{ml}$ do meio fermentado foi transferido para tubos e centrifugados a 2250 rpm $(450 \mathrm{G})$ durante 5 minutos. $O$ sobrenadante foi descartado e o precipitado foi lavado com água destilada gelada e realizada nova centrifugação. Os tubos contendo o precipitado de células foram secos em estufa a $105-110^{\circ} \mathrm{C}$ até obtenção de peso constante. 


\subsection{Análises Estatísticas}

As análises estatisticas foram realizadas segundo GOVIES (1987).

Para o ensaio com baixa concentração de inóculo e sem reciclo de células foi utilizado o delineamento experimental inteiramente ao acaso. Para o ensaio com alta concentração de inóculo foi utilizado o delineamento em Parcelas subdivididas com 3 repetições.

Para a comparação de médias foi utilizado o teste de Tukey para todas as variaveis analisadas. 


\section{RESULTADOS E DISCUSSÃO}

Os dados oniginais $\mathrm{e}$ as análises estatisticas dos ensaios realizados se encontram no Apêndice - página 75 .

\subsection{Ensaio sem Reciclo de Células}

\subsubsection{Teor de Matéria Seca e Crescimento}

Na tabela 2 são encontradas as médias obtidas para o teor de matéria seca $(\mathrm{g} / 100 \mathrm{ml}$ ) e na tabela 3 são encontrados os resultados de crescimento após fermentação em meio com 5 e $12 \%$ de ART. A variável crescimento não foi analisada estatisticamente.

O maior valor para o teor de matéria seca obtido de todos os experimentos realizados, apesar de não terem sido feitas análises estatísticas entre os experimentos, apenas dentro de cada experimento, foi obtido com a levedura IZ $980(0.27 \mathrm{~g} / 100 \mathrm{ml})$ apesar de nào ter havido diferença significativa ao nível de 5\% de significância, em relação as demais leveduras testadas nesse experimento, provavelmente devido ao alto coeficiente de variação (de aproximadamente 26\%). Apesar do alto teor de matéria seca foi encontrada baixa viabilidade celular.

Não houve grande variação no teor de matéria seca apresentada pelas leveduras nos experimentos realizados. mas apesar disso houve grande variação na viabilidade celular e brotamento. Não foi possivel fazer nenhuma correlação entre o teor de matéria seca, brotamento e viabilidade celular.

O menor valor do teor de matéria seca e crescimento em meio de fermentação a 5\% de ART foi obtido para a levedura IZ 1904, apesar da alta viabilidade e alto brotamento celular. 
Tabela 2. Teor de matéria seca $(\mathrm{g} / 100 \mathrm{ml})$ de leveduras após fermentação em meio de mosto de melaço com 5 e $12 \%$ de ART, sem reciclo de células, (pH $4.0=$ Temperatura $40^{\circ} \mathrm{C}$ ).

\begin{tabular}{|c|c|c|c|c|}
\hline \multirow{2}{*}{$\begin{array}{l}\text { Meio de Ferm. } \\
\% \text { de ART }\end{array}$} & \multicolumn{3}{|c|}{ Teor de Matéria } & \multirow[b]{2}{*}{ C.V. $(\%)$} \\
\hline & Leveduras & Seca & d.m.s. & \\
\hline \multirow{4}{*}{5} & IZ 1831 & $0.21 \mathrm{a}$ & - & 14.16 \\
\hline & IZ 1834 & $0.17 \mathrm{ab}$ & & \\
\hline & IZ 222 & $0.16 \mathrm{~b}$ & & \\
\hline & IZ 270 & $0.16 \mathrm{~b}$ & & \\
\hline \multirow{5}{*}{$* 5$} & 12860 & $0.19 a$ & 0.14194 & 26.02 \\
\hline & IZ 980 & $0.27 \mathrm{a}$ & & \\
\hline & IZ 878 & $0.18 \mathrm{a}$ & & \\
\hline & IZ 888 & $0.19 \mathrm{a}$ & & \\
\hline & LZ 879 & $0.19 \mathrm{a}$ & & \\
\hline \multirow{5}{*}{5} & IZ 1904 & $0.14 \mathrm{a}$ & 0.036 & 9.00 \\
\hline & IZ 1279 & $0.19 \mathrm{~b}$ & & \\
\hline & IZ 1352 & $0.18 b$ & & \\
\hline & IZ 1256 & $0.17 b c$ & & \\
\hline & IZ 1831 & $0.24 \quad \mathrm{c}$ & & \\
\hline \multirow{5}{*}{12} & IZ 1904 & $0.31 \mathrm{a}$ & 0.11565 & 14.99 \\
\hline & IZ 888 & $0.38 \mathrm{a}$ & & \\
\hline & IZ 1831 & $0.41 \mathrm{a}$ & & \\
\hline & IZ 860 & $0.31 \mathrm{a}$ & & \\
\hline & IZ 1279 & $0.35 \mathrm{a}$ & & \\
\hline
\end{tabular}

* No experimento 2 as médias representam três repetições e nos demais representam quatro repetições.

Letras diferentes há diferença estatisticamente significativa ao nivel de $5 \%$ de significância entre as médias. 
Tabela 3. Biomassa (g/100 mi) de leveduras após fermentação em meio de mosto de melaço com 5 e $12 \%$ de ART, sem reciclo de células. ( $\mathrm{pH} 4.0$ - Temperatura $40^{\circ} \mathrm{C}$ ).

\begin{tabular}{|c|c|c|}
\hline \multicolumn{3}{|l|}{ Meio de Ferm. } \\
\hline$\%$ de ART & Leveduras & Crescimento** \\
\hline & IZ 1831 & 0.16 \\
\hline \multirow[t]{5}{*}{5} & IZ 1834 & 0.12 \\
\hline & 12222 & 0.11 \\
\hline & IZ 270 & 0.10 \\
\hline & IZ 860 & 0.14 \\
\hline & IZ 980 & 0.22 \\
\hline \multirow[t]{5}{*}{$5 *$} & IZ 878 & 0.13 \\
\hline & IZ 888 & 0.14 \\
\hline & IZ 879 & 0,14 \\
\hline & IZ 1904 & 0.09 \\
\hline & IZ 1279 & 0.13 \\
\hline \multirow[t]{5}{*}{5} & IZ 1352 & 0.13 \\
\hline & IZ 1256 & 0.12 \\
\hline & IZ 1831 & 0.18 \\
\hline & IZ 1904 & 0.25 \\
\hline & IZ 888 & 0.33 \\
\hline \multirow[t]{3}{*}{12} & IZ 1831 & 0.36 \\
\hline & IZ 860 & 0.26 \\
\hline & IZ 1279 & 0.30 \\
\hline
\end{tabular}

* No experimento 2 as médias foram obtidas com três repetições e nos demais com quatro repetições.

** Não foram feitas análises estatísticas. 
Com o aumento da concentração de açúcar no meio de $5 \%$ para $12 \%$ de ART houve aumento no teor de materia seca para todas as leveduras, o que era de se esperar com o aumento da fonte de carbono.

ZAGO (1982) verificou uma correlação positiva entre quantidade de matéria seca produzida e percentagem de brotamento tanto para a levedura M-300-A como também para a levedura de panificação Fleischmann. No presente ensaio com meio de fermentação a $5 \%$ de ART não foi possivel fazer uma relação positiva entre o teor de matéria seca, crescimento e brotamento celular. sendo que as leveduras IZ 222 e IZ 1904 apresentaram os valores mais altos de brotamento (Tabela 5) com os valores mais baixos de crescimento.

Durante a fermentação alcoólica. é desejável que ocorra algum crescimento para substituir as células mortas, bem como aquelas perdidas nos processos de centrifugação e reciclagem das células para o fermentador NAGODAWTTHANA et al, 1974). Com base nessa afirmação seria necessário observar esse paråmetro para a escolha da levedura termotolerante que seria utilizada em fermentação industrial a $40^{\circ} \mathrm{C}$.

Com relação aos valores de crescimento da tabela 3 , é possivel observar que a levedura IZ 1904 não seria indicada para utilização industrial sob essa temperatura, pois haveria dificuldade na substituição das células mortas e perdidas durante o processo de reciclo de células.

$O$ crescimento exagerado da levedura também é prejudicial, pois nesse caso o açúcar do meio estaria sendo desviado para a formaçăo de material celular, prejudicando a produção de etanol.

No experimento onde a concentração de açúcar foi de $12 \%$ de ART o maior crescimento ocorreu com a levedura $I Z 1831$ e o menor com a levedura $I Z 1904$, apesar desses resultados, não houve diferença estatisticamente significativa entre elas ao nível de $5 \%$ de significância com relação a produção de etanol, mostrando que o maior ou menor crescimento não afetou a produção de etanol nesse ensaio já que a produção de etanol não variou entre as linhagens estudadas.

GUTIERREZ (1989), verificou utilizando linhagens de Saccharomyces que com o aumento da concentração de sacarose no meio houve aumento de crescimento e diminuição da eficiência da fermentação. WADA et al. (1981) verificaram que o aumento de 10 para $25 \%$ de glucose no meio reduziu o crescimento das celulas de Saccharomyces cerevisiae imobilizadas. No presente ensaio quando a concentração de açúcar do meio foi aumentada de 5 para $12 \%$ de ART houve aumento do crescimento. 
PARADA \& ACEVEDO (1983) verificaram que aumentando a temperatura de $20^{\circ} \mathrm{C}$ para $35^{\circ} \mathrm{C}$ houve diminuição do conteúdo de RNA das células de Saccharomyces cerevisiae ocorrendo cerca de $43 \%$ de redução. Essa reduçào no conteúdo de RNA poderia explicar o menor crescimento da levedura IZ 1904 no nosso experimento quando comparamos com os dados obtidos por GUTIERREZ (1989) em temperatura mais baixa, sendo que a temperatura de $40^{\circ} \mathrm{C}$ estaria influenciando no conteúdo de RNA destas células.

\subsubsection{Viabilidade Celular e Brotamento}

Na tabela 4 săo apresentados os valores de viabilidade celular dos experimentos em meio de fermentação a 5 e $12 \%$ de ART.

Houve diferenças marcantes em relação aos valores de viabilidade celular entre as leveduras. O maior valor obtido entre todos os experimentos em meio com $5 \%$ de ART e a $40^{\circ} \mathrm{C}$ foi obtido com a levedura IZ 1831, apesar de não terem sido feitas análises estatísticas entre os experimentos. porém houve diminuição da viabilidade celular quando esta levedura foi colocada para fermentar em meio com maior concentração de açúcar $(12 \%$ ART).

De um modo geral houve diminuição de viabilidade celular para todas as leveduras que foram testadas em meio com $5 \%$ de ART e depois testadas em meio com $12 \%$ de ART, exceto a levedura IZ 888 que apresentou aumento de viabilidade celular com a elevação da osmolaridade do meio, mostrando que essa levedura não foi prejudicada por esse fator, em temperatura de $40^{\circ} \mathrm{C}$. Segundo SLAP.ACK et al. (1987) a osmotolerância também é uma caracteristica importante para microrganismos utilizados industrialmente.

Com base na discussão acima é possivel afirmar que a levedura IZ 1831 apesar de ter apresentado alta viabilidade celular em meio com $5 \%$ de ART não seria indicada para utilização em fermentações industriais já que estas ocorrem em meio com maior concentração de açúcar. A concentração de $12 \%$ de ART ainda está abaixo do normalmente utilizado nas destilarias que é por volta de 14 a $18 \%$ ART. 
Tabela 4. Viabilidade celular $(\%)$ de leveduras após fermentação em meio de mosto de melaço com 5 e $12 \%$ de ART, sem reciclo de células, $(\mathrm{pH} 4.0$ - Temperatura $\left.40^{\circ} \mathrm{C}\right)$.

\begin{tabular}{|c|c|c|c|c|}
\hline $\begin{array}{l}\text { Meio de Ferm. } \\
\% \text { de ART }\end{array}$ & Leveduras & Viabilidade $(\%)$ & d.m.s. & $\mathrm{C.V}$. \\
\hline & IZ 1831 & 87.85 & -- & -- \\
\hline \multirow[t]{5}{*}{$* 5$} & IZ 1834 & 70.56 & & \\
\hline & IZ 222 & 96.61 & & \\
\hline & IZ 270 & 44.87 & & \\
\hline & IZ 860 & 92.98 & 5.5653 & 3.917 \\
\hline & IZ 980 & 57.03 & & \\
\hline \multirow[t]{5}{*}{$* * 5$} & IZ 878 & 24.14 & & \\
\hline & IZ 888 & 92.98 & & \\
\hline & IZ 879 & 35.9 & & \\
\hline & IZ 1904 & 90.42 & 4.2385 & 2.74 \\
\hline & Z 1279 & 86.73 & & \\
\hline \multirow[t]{5}{*}{$* * 5$} & IZ 1352 & 82.42 & & \\
\hline & IZ 1256 & 85.39 & & \\
\hline & IZ 1831 & 96.71 & & \\
\hline & IZ 1904 & 77.20 & 8.9125 & 6.122 \\
\hline & IZ 888 & 95.73 & & \\
\hline \multirow[t]{3}{*}{$* * 12$} & IZ 1831 & 87.97 & & \\
\hline & IZ 860 & 71.72 & & \\
\hline & IZ 1279 & 83.44 & & \\
\hline
\end{tabular}

* No experimento 1 não foi feita análise estatística devido ao número insuficiente de repetições.

** No experimento 3 e 4 as médias representam quatro repetições e no experimento 2 representam três repetições. 
A levedura IZ 1904 que é uma levedura utilizada industrialmente apresenta bom desempenho fermentativo em temperaturas mais baixas. Essa levedura quando foi testada em meio com $5 \%$ de ART apresentou alta viabilidade celular, porém com o aumento da concentração de açúcar para $12 \%$ de ART houve diminuição da viabilidade. demonstrando que essa levedura foi prejudicada pela temperatura de $40^{\circ} \mathrm{C}$ e esse efeito foi agravado com o aumento da concentraçào de açúcar no meio para $12 \%$ de ART. A temperatura do presente trabalho poderia estar influenciando o transporte de açúcar para dentro da célula.

A temperatura de $40^{\circ} \mathrm{C}$ do nosso trabalho poderia explicar a baixa viabilidade celular de muitas linhagens tanto em meio com 5 ou $12 \%$ de ART. CASEY et al. (1984) encontraram. utilizando Saccharomyces cerevisiae, que com a elevação da temperatura havia diminuição da viabilidade celular, segundo eles, seria devido a limitação de nutrientes. como o oxigênio e o nitrogênio assimilavel.

No trabalho descrito acima foi utilizado meio com alta pressão osmótica e elevação da temperatura, sendo que segundo os autores a diminuição da viabilidade celular seria devido a maior sintese celular e fermentação mais rápida nessas condições, o que provavelmente estaria ocorrendo no presente trabalho quando a concentração de açúcar do meio foi aumentada de 5 para $12 \%$ de ART.

$O$ acúmulo de trealose estaria relacionado a maior ou menor viabilidade celular, principalmente no meio de fermentação com maior concentração de açúcar e será discutido no item 4.1.4.

A levedura LZ 878 testada em meio com 5\% de ART apresentou a menor viabilidade de todas as leveduras testadas em meio com 5 e $12 \%$ de ART, demonstrando que com essa linhagem de levedura ocorre predominância de morte celular a $40^{\circ} \mathrm{C}$. KROUWEL \& BRABER (1979) utilizando uma linhagem de Saccharomyces cerevisiae verificaram que acima de $39,6^{\circ} \mathrm{C}$ havia predominância de morte celular.

As leveduras IZ 860, IZ 888, IZ 1279, além das leveduras IZ 1831 e IZ 1904 já citadas, apresentaram as mais altas viabilidades celulares em meio de fermentação com $5 \%$ de ART e por esse motivo foram escolhidas para serem testadas em meio com $12 \%$ de ART. A partir desses resultados foram escolhidas as leveduras que seriam testadas no ensaio com reciclo de células.

As leveduras que foram testadas em meio com $5 \%$ de ART e apresentaram baixa viabilidade celular não seriam indicadas em temperatura de $40^{\circ} \mathrm{C}$ para a utilização 
industrial, onde é utilizado o sistema de reciclo de células no qual as leveduras devem manter uma alta viabilidade celular após cada ciclo fermentativo.

A levedura $1 Z 888$ apresentou alta viabilidade celular após fermentação em meio com $12 \%$ de ART, sendo esse o principal parametro para a escolha dessa levedura para o ensaio com reciclo de celulas. Apesar de não ter havido diferença estatisticamente significativa ao nível de $5 \%$ de significância entre as leveduras $I Z 888$ e $Z$ Z 1831 , a primeira apresentou aumento de viabilidade celular quando a concentração do meio de fermentação foi elevada de 5 para $12 \%$ de ART sendo mais indicada para o uso industrial com reciclo de células.

Na tabela 5 são apresentados os resultados de brotamento celular. Os maiores valores de brotamento celular entre os experimentos foram obtidos pelas leveduras IZ 222 e IZ 1904 em meio de fermentaçăo com 5\% de ART, apesar de não terem sido feitas análises estatísticas entre os experimentos. O menor valor foi obtido para a levedura IZ 270.

Foi verificado por PEISNNO (1986) que o brotamento, a viabilidade dos brotos e o crescimento celular foram negativamente afetados pelo aumento da temperatura de fermentação, o que estaria ocorrendo para algumas linhagens de levedura no presente trabalho.

A levedura IZ 222 apresentou o mais alto valor de brotamento e viabilidade celular entre todos os experimentos realizados nesse ensaio, apesar de não terem sido feitas análises estatísticas entre os experimentos. Essa levedura apesar da alta viabilidade celular não seria indicada industrialmente devido a baixa produção de etanol, provavelmente a temperatura de $40^{\circ} \mathrm{C}$ estaria afetando as enzimas responsáveis pela conversão do açúcar em etanol. 
Tabela 5. Brotamento celular (\%) de leveduras após fermentação em meio de mosto de melaço com 5 e $12 \%$ de ART, sem reciclo de células, (pH 4.0 - Temperatura $40^{\circ} \mathrm{C}$ ).

Meio de Ferm.

\begin{tabular}{|c|c|c|c|c|}
\hline$\%$ de ART & Leveduras & Brotamento $(\%)$ & d.m.s. & C.V. \\
\hline & IZ 1831 & 17.02 & -- & -- \\
\hline \multirow[t]{5}{*}{$* 5$} & IZ 1834 & 13.66 & & \\
\hline & IZ 222 & 32.46 & & \\
\hline & IZ 270 & 2.86 & & \\
\hline & IZ 860 & 15.29 & 7.14 & 11.90 \\
\hline & IZ 980 & 14.89 & & \\
\hline \multirow[t]{5}{*}{$* * 5$} & IZ 878 & 14.69 & & \\
\hline & IZ 888 & 14.67 & & \\
\hline & IZ 879 & 12.92 & & \\
\hline & IZ 1904 & 22.58 & 4.94 & 10.56 \\
\hline & IZ 1279 & 17.51 & & \\
\hline \multirow[t]{5}{*}{$* * 5$} & IZ 1352 & 15.37 & & \\
\hline & IZ 1256 & 9.06 & & \\
\hline & IZ 1831 & 5.34 & & \\
\hline & IZ 1904 & 12.74 & 7.05 & 18.46 \\
\hline & IZ 888 & 10.97 & & \\
\hline \multirow[t]{3}{*}{$* * 12$} & IZ 1831 & 4.80 & & \\
\hline & IZ 860 & 12.49 & & \\
\hline & IZ 1279 & 5.70 & & \\
\hline
\end{tabular}

* Não foram feitas análises estatísticas para o primeiro experimento devido ao número insuficiente de repetições.

** No experimento 3 e 4 as médias representam quatro repetições e no experimento 2 representam três repetições. 


\subsubsection{Etanol}

Na tabela 6 são apresentados os valores de produção de etanol pelas leveduras estudadas no ensaio com baixa concentração de inóculo e sem reciclo de células em meio de fermentação com 5 e $12 \%$ de ART.

A levedura que apresentou o menor valor de todos os experimentos para a produção de etanol foi a IZ 222 em meio a $5 \%$ de ART, apesar de não terem sido féitas análises estatísticas entre os experimentos, apenas dentro de cada experimento. Em meio de fermentação com 5\% de ART, apesar da concentração de açúcar ser baixa a levedura IZ 222 poderia estar formando subprodutos como o glicerol, que não foi analisado no presente ensaio.

Com a produção de glicerol há redução na produção de etanol. NORDSTROM (1966) verificou que a biossintese de material celular é um processo que produz NADH e assim contribue para a formação do glicerol. Os dados obtidos do teor de matéria seca e crescimento para a levedura IZ 222 não são altos em comparação com os valores obtidos para as demais leveduras testadas, não sendo a baixa produção de etanol justificada pela afirmação acima .

Foi relatado por RANKINE \& BRIDSON (1971) que em temperaturas mais elevadas houve maior produção de glicerol e segundo RADLER \& SCHULTZ (1982) outro fator que pode interferir na formação do glicerol é a linhagem da levedura, que pode produzir mais ou menos glicerol. A baixa produção de etanol pela levedura IZ 222 poderia ser explicada pelos relatos acima.

A baixa produção de etanol pela levedura IZ 222 poderia ser explicada pelo efeito da alta temperatura $\left(40^{\circ} \mathrm{C}\right)$ utilizada no nosso experimento, o que poderia estar prejudicando a atividade de alguma enzima do processo fermentativo.

Conforme é possivel observar na tabela 6 não houve variação entre os resultados dos experimentos 2 e 3 , sendo assim não foram feitas análises estatísticas, sendo estas realizadas apenas para os experimentos 1 e 4 . No experimento 4 não houve diferença significativa ao nivel de $5 \%$ de significância entre os valores encontrados.

No experimento com $12 \%$ de ART foram utilizadas as leveduras com melhor resultado nos experimentos anteriores. 
Tabela 6. Porcentagem de Etanol (v/v) produzido por leveduras após fermentação em meio de mosto de melaço com 5 e $12 \%$ de ART, sem reciclo de células. (pH 4.0 - Temperatura $40^{\circ} \mathrm{C}$ ).

\begin{tabular}{|c|c|c|c|c|}
\hline $\begin{array}{c}\text { Meio de Ferm. } \\
\% \text { de ART }\end{array}$ & Leveduras & Etanol & d.m.s. & C.V. \\
\hline & IZ 1831 & 2.28 & 0.11227 & 2.736 \\
\hline \multirow[t]{5}{*}{5} & IZ 1834 & 2.28 & & \\
\hline & IZ 222 & 0.87 & & \\
\hline & IZ 270 & 2.38 & & \\
\hline & LZ 860 & 2.28 & -- & -- \\
\hline & IZ 980 & 2.28 & & \\
\hline \multirow[t]{5}{*}{$* 5$} & IZ 878 & 2.28 & & \\
\hline & IZ 888 & 2.28 & & \\
\hline & IZ 879 & 2.28 & & \\
\hline & IZ 1904 & 2.28 & -- & -- \\
\hline & IZ 1279 & 2.28 & & \\
\hline \multirow[t]{5}{*}{$* 5$} & IZ. 1352 & 2.28 & & \\
\hline & IZ 1256 & 2.28 & & \\
\hline & IZ 1831 & 2.28 & & \\
\hline & IZ 1904 & 5.58 & 0.10715 & 0.881 \\
\hline & IZ 888 & 5.58 & & \\
\hline \multirow[t]{3}{*}{12} & IZ 1831 & 5.58 & & \\
\hline & IZ 860 & 5.54 & & \\
\hline & IZ 1279 & 5.54 & & \\
\hline
\end{tabular}

* Não foram feitas análises estatísticas para o experimento 2 e 3. 
A produção de etanol não variou estatisticamente ao nivel de $5 \%$ de significância entre as leveduras testadas em meio de fermentação com $12 \%$ de ART, porém, as leveduras se mostraram mais ou menos tolerantes ao etanol produzido dependendo da linhagem. As leveduras IZ 888 e IZ 1831 se mostraram mais tolerantes ao etanol produzido pois apresentaram aita viabilidade celular sendo $95.73 \%$ e $87.97 \%$, respectivamente, (Tabela 4 ).

A maior tolerância ao etanol produzido pelas leveduras citadas acima pode estar relacionada com a composição em ácidos grayos da membrana citoplasmática e também ao maior acúmulo de trealose o que diminuiria o efeito de desidratação causado pelo etanol. Há escassez de literatura relacionando acúmulo de trealose com produção e tolerância ao etanol.

É conhecido que com o aumento da temperatura aumenta a intolerància da levedura ao etanol (GRAY, 1941; NAGODOWTTHANA et al., 1974 e NAVARRO \& DURAND, 1978). Com base na afirmaçào acima é possivel inferir que a temperatura de $40^{\circ} \mathrm{C}$ provavelmente esteja aumentando a intolerância das leveduras estudadas ao etanol. porém a menor ou maior intensidade desta intolerância está relacionada com a linhagem e pode explicar as diferenças de viabilidade celular entre as leveduras.

As leveduras possuem a capacidade de alterar a composição em ácidos graxos da membrana citoplasmática quando há mudança de temperatura. SUUTARI et al. (1990) verificaram que leveduras de gêneros diferentes mostravam respostas diferentes a mudança de temperatura, o que pode estar ocorrendo com as leveduras estudadas, apesar de não serem de gèneros diferentes, cada linhagem apresentou uma resposta em fermentação com temperatura de $40^{\circ} \mathrm{C}$ e essa resposta também seria diferente com relação a tolerância ao etanol produzido.

Considerando somente as variáveis etanol e viabilidade celular, as leveduras IZ 888 e IZ 1831 mostraram boa tolerância ao etanol produzido e a temperatura, mantendo alta viabilidade celular, que segundo SLAPACK et al. (1987) estas são algumas caracteristicas importantes que os microrganismos devem possuir para serem utilizados na produção de etanol.

Em meio de fermentação com $12 \%$ de ART as leveduras mais tolerantes ao etanol, ou seja, que apresentaram uma alta viabilidade celular após a fermentação (Tabela 4), foram as que apresentaram maior teor de trealose, sendo possível relacionar o acúmulo desse carboidrato com a proteção contra o etanol, que é um agente estressante para a levedura. 
Com os resultados apresentados na tabela 6 é possivel observar que não houve grande variação na produção de etanol para as leveduras. tanto em meio de fermentação com 5 ou $12 \%$ de ART, provavelmente com um próximo ciclo fermentativo seria possivel detectar diferenças de comportamento entre as leveduras com relação a produção deste metabólito.

\subsubsection{Trealose}

Na tabela 7 são apresentados os resultados do acumulo de trealose pelas leveduras em meio com 5 e $12 \%$ de ART.

Após fermentação em meio com $5^{\circ} \%$ de ART o maior acúmulo de trealose foi encontrado na levedura IZ 1831. O menor teor de trealose foi encontrado para a levedura IZ 270 apesar de não terem sido feitas análises estatísticas entre os experimentos. apenas dentro de cada experimento.

A levedura IZ 270 apresentou baixo teor de trealose é é possivel observar na tabela 4 que esta linhagem apresentou baixa viabilidade celular. encontrado também por GUTIERREZ (1989). Foi encontrado no presente trabalho em meio de fermentação com $5 \%$ de ART que há linhagens com baixo teor de trealose e alta viabilidade e alto teor de trealose e baixa viabilidade celular.

Os resultados obtidos com o teor de trealose e viabilidade celular reforçam a hipótese de que outras variáveis estejam envolvidas, principalmente a composição em ácidos graxos da membrana citoplasmática das células de leveduras, conforme encontrado por WATSON (1982), a limitação do nivel de magnésio conforme relatado por DOMBEK \& INGRAM (1986) e o teor de cálcio no meio de fermentação segundo NABAIS et al., (1988).

Para que fique claro esse mecanismo seria necessário em um próximo trabalho analisar a composição em ácidos graxos das leveduras estudadas, principalmente da levedura IZ 222, IZ 1904, IZ 1279, IZ 1256, que apresentaram baixo acúmulo de trealose e alta viabilidade celular em meio de fermentação com 5\% de ART e em temperatura de $40^{\circ} \mathrm{C}$. 
Tabela 7. Acúmulo de Trealose (g/100 g de biomassa seca) em leveduras após fermentação em meio de mosto de melaço com 5 e $12 \%$ de ART, sem reciclo de células. ( $\mathrm{pH} 4.0$ - Temperatura $40^{\circ} \mathrm{C}$ ).

Meio de Ferm.

\begin{tabular}{|c|c|c|c|c|}
\hline$\%$ de ART & Leveduras & Trealose & d.m.s. & C.V. \\
\hline & IZ 1831 & $6.38 \mathrm{a}$ & -- & 44.45 \\
\hline \multirow[t]{5}{*}{5} & IZ 1834 & $2.59 \quad b$ & & \\
\hline & IZ 222 & $1.08 \mathrm{~b}$ & & \\
\hline & IZ 270 & $0.42 \mathrm{~b}$ & & \\
\hline & IZ 860 & $0.94 \mathrm{ab}$ & 1.44 & 41.73 \\
\hline & IZ 980 & $1.50 \mathrm{ab}$ & & \\
\hline \multirow[t]{5}{*}{5} & 12878 & $0.57 \mathrm{~b}$ & & \\
\hline & IZ 888 & $2.36 \mathrm{a}$ & & \\
\hline & IZ 879 & $1.07 \mathrm{ab}$ & & \\
\hline & IZ 1904 & $0.81 \mathrm{a}$ & 4.94 & 10.56 \\
\hline & IZ 1279 & $0.78 \mathrm{ab}$ & & \\
\hline \multirow[t]{5}{*}{5} & IZ 1352 & $1.23 \mathrm{ab}$ & & \\
\hline & IZ 1256 & $0.96 \mathrm{ab}$ & & \\
\hline & IZ 1831 & $5.01 \mathrm{~b}$ & & \\
\hline & IZ 1904 & $0.44 \mathrm{~b}$ & 0.71 & 17.43 \\
\hline & IZ 888 & $3.53 \mathrm{a}$ & & \\
\hline \multirow[t]{3}{*}{12} & IZ 1831 & $4.18 \mathrm{a}$ & & \\
\hline & IZ 860 & $0.82 \quad b$ & & \\
\hline & IZ 1279 & $0.35 \mathrm{~b}$ & & \\
\hline
\end{tabular}

Médias com letras iguais não possuem diferença entre si ao nivel de $5 \%$ de significância. 
Em meio de fermentação com $12 \%$ de ART foi possivel observar que as leveduras IZ 888 e IZ 1831 apresentaram os mais altos valores de acúmulo de trealose. não havendo diferença estatisticamente significativa ao nivel de $5 \%$ de significância entre elas. O maior acúmulo de trealose por essas leveduras foi acompanhado dos valores mais altos de viabilidade celular. sendo que as leveduras com menor acúmulo do carboidrato apresentaram menor viabilidade celular, sendo possivel nesse experimento fazer uma relação em meio com $12 \%$ de ART entre o acúmulo de trealose e viabilidade celular, sendo as médias para as duas variáveis apresentadas abaixo:

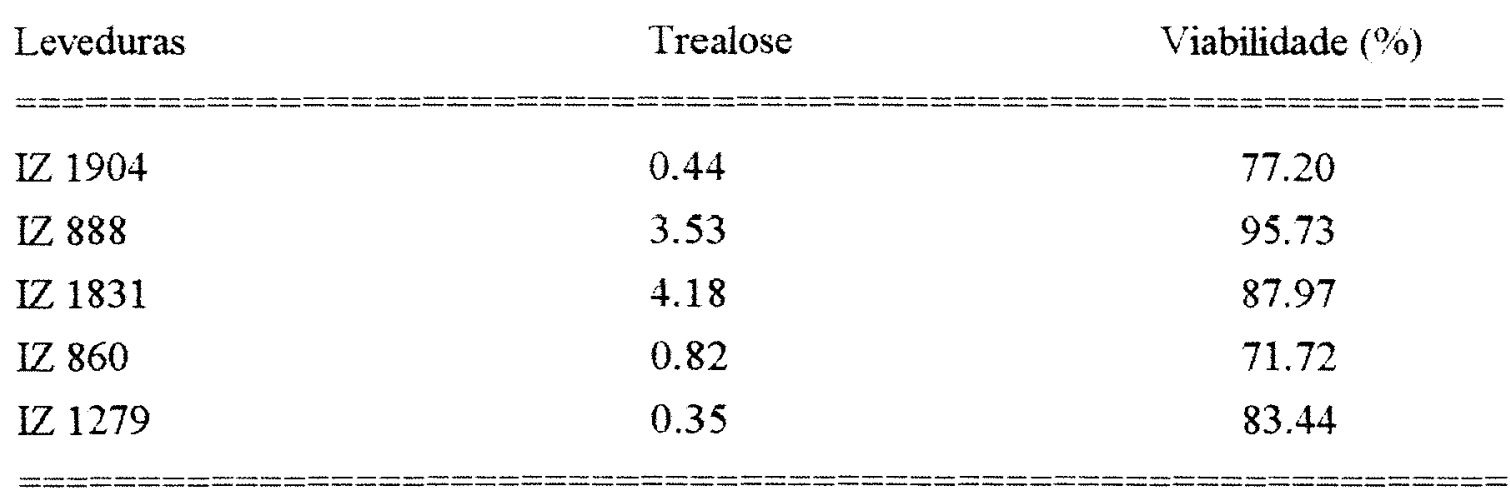

A levedura IZ 1904 apresentou baixo acúmulo de trealose em meio a 5\% de ART (Tabela 7), porém a sua viabilidade celular foi alta (Tabela 4). Essa mesma levedura em meio a $12 \%$ de ART apresentou baixo acúmulo de trealose e baixa viabilidade celular. Baseado nesse resultado é possivel inferir que o baixo acúmulo desse carboidrato leva a uma menor proteção da célula contra fatores estressantes, no caso a alta temperatura do ensaio e o aumento de pressão osmótica.

Com o aumento da pressão osmótica do meio de fermentação de 5 para $12 \%$ de ART houve diminuição do acúmulo de trealose pelas leveduras testadas nas duas concentrações, sendo que o esperado seria ocorrer aumento, devido a pressão osmótica representar um fator estressante para a levedura, porém essa concentração de $12 \%$ de ART pode não ter sido suficiente para desencadear uma maior biossíntese de trealose. 
GUTIERREZ (1989) encontrou que a levedura 121904 apresentou um alto teor de trealose e uma alta viabilidade celular em meio sintético com $14 \%$ de sacarose e em fermentação a $35^{\circ} \mathrm{C}$. GUTIERREZ (1990) verificou que houve aumento no acúmulo de trealose com elevação da temperatura de 12 para $34^{\circ} \mathrm{C}$ para a levedura $\mathrm{IZ}$ 1904. porém no nosso trabalho a $40^{\circ} \mathrm{C}$ essa levedura apresentou baixo acúmulo de trealose tanto em meio com 5 e $12 \%$ de ART.

Os resultados do presente trabalho não corroboram os descritos acima para a levedura IZ 1904 devido provavelmente ao meio utilizado no nosso trabalho não ser um meio sintético e sim um meio de melaço. A biossintese de trealose nesse caso poderia estar sendo influenciada pela composição do meio para essa levedura.

Segundo GRBA et al. (1975) a temperatura elevada $\left(40^{\circ} \mathrm{C}\right)$ ocasiona maior formação de trealose, o que não foi encontrado para algumas leveduras testadas no presente trabalho, com enfase na levedura IZ 1904 que é uma levedura utilizada industrialmente.

Foi observado que a levedura IZ 1904 apresentou baixo crescimento em meio com 5 e 12\% de ART (Tabela 3), apesar de não ter sido feita análise estatística para essa variável, juntamente com baixo acúmulo de trealose. THEVELELN (1984) encontrou que quando a taxa de crescimento é reduzida ocorre acúmulo de trealose, sendo que com o estimulo do crescimento há rápida degradação da trealose. Os nossos resultados não corroboram os descritos pelo autor pelo menos para essa levedura.

Segundo PANEK (1971) as condições anaeróbicas em meio com 2\% de glucose reduzem a quantidade de trealose acumulada pelas leveduras, sendo que a energia produzida durante a glicólise anaeróbica não permite o armazenamento do carboidrato.

Os resultados obtidos no nosso trabalho em meio com 5\% de ART e em anaerobiose não corroboram os encontrados por PANEK (1971), já que a levedura IZ 1831 acumulou alto teor de trealose nessas condições. Quando essa mesma levedura foi colocada para fermentar em meio com $12 \%$ de ART e em condições de anaerobiose era de se esperar que houvesse um aumento da energia produzida durante a glicólise porém, ao contrário do esperado houve diminuição para todas as leveduras exceto para a IZ 888 .

No presente trabalho foram realizadas dosagens apenas da trealose após fermentação, sendo que em um trabalho futuro poderia ser feita a dosagem inicial e após fermentação para melhor observação do acúmulo de trealose pelas leveduras.

Em trabalhos encontrados sobre o acumulo de trealose em leveduras sob altas temperaturas, geralmente é utilizada a técnica do choque térmico, onde as culturas 
que estão sob temperatura mais baixas são submetidas a altas temperaturas por um curto periodo de tempo. No presente trabalho a temperatura de $40^{\circ} \mathrm{C}$ foi mantida constante durante toda a fermentação. o que pode causar diferenças na obtençào dos resultados.

\subsection{Ensaio com Reciclo de Células}

\subsubsection{Reciclo de Células}

Foram comparadas as leveduras IZ 888 (selecionada nos experimentos anteriores devido a maior viabilidade, brotamento e acúmulo de trealose) com as leveduras industrialmente utilizadas IZ 1904 e M-300-A.

No presente ensaio foram realizadas 4 e 5 fermentações alcoólicas consecutivas com reciclagem do fermento em meio com $12 \%$ de ART, sem a suplementação de sais e em temperatura de $40^{\circ} \mathrm{C}$.

As séries de experimentos com reciclos de células foram realizadas para avaliar o comportamento fermentativo, produçăo de etanol, glicerol, viabilidade, brotamento celular e açúcares redutores residuais, tentando simular a condição utilizada em destilarias.

$O$ reciclo de células realizado nesse ensaio com as leveduras testadas anteriormente em fermentações com um único ciclo fermentativo, consideram diferenças que poderiam não ocorrer em fermentações sem reciclo de células.

Durante o reciclo de células foi possivel observar que a levedura IZ 1904 é pouco resistente a reciclagem do fermento em temperatura de $40^{\circ} \mathrm{C}$ o que pode ser percebido com a diminuição acentuada da viabilidade celular após cada ciclo fermentativo.

As leveduras IZ 888 e M-300-A apresentaram um comportamento superior a IZ 1904 com relação as variaveis analisadas após cada ciclo fermentativo, principalmente em relação a viabilidade celular. Com as leveduras IZ 888 e M-300-A foi possivel um 
quinto reciclo de células sendo que a IZ 1904 consegue suportar até o quarto reciclo. porém com baixa viabilidade celular.

Na indústria. importante que após cada ciclo fermentativo as leveduras mantenham uma alta viabilidade celular, devido ao método de reciclagem de fermento utilizado. A levedura IZ 1904 não seria indicada para utilização a $40^{\circ} \mathrm{C}$ com reciclo de células.

\subsubsection{Crescimento Celular após cada Ciclo Fermentativo}

Na tabela 8 são apresentados os resultados obtidos no experimento onde foram comparadas a levedura IZ $888 \mathrm{com}$ a levedura M-300-A. A levedura M-300-A apresentou maior perda de massa celular no total, após todos os reciclos de células, e a levedura IZ 888 apresentou menor perda de massa celular, sendo esse um parâmetro muito importante para a utilização industrial.

$\mathrm{Na}$ tabela 9 estão os resultados obtidos no experimento onde foram comparadas as leveduras IZ 888 e IZ 1904. A levedura IZ 1904 apresentou grande perda de massa celular após os reciclos de células e a levedura IZ 888 apresentou menor perda celular após os reciclos, demonstrando um ligeiro aumento. A levedura 121904 não seria indicada para utilização industrial a $40^{\circ} \mathrm{C}$, pois nas indústrias onde é utilizado o sistema de reciclo de células é desejado o mínimo de perda celular.

Os valores de perda celular para as leveduras IZ 1904 e IZ 888 são relacionados com a viabilidade selular, ou seja, quando ocorre autólise das células estas são eliminadas com o processo de centrifugação, sendo essa perda acompanhada no presente trabalho através do peso de fermento úmido, após cada ciclo fermentativo.

Os valores de viabilidade celular (Tabela 11) são baixos nos dois últimos ciclos para a levedura IZ 1904, concomitantemente ocorrendo maior perda celular nesses ciclos. 
Tabela 8. Acompanhamento do peso de fermento úmido $(\mathrm{g} 100 \mathrm{ml}$ ) durante os ciclos fermentativos das leveduras IZ 888 e M-300-A, em meio de mosto de melaço com $12 \%$ de ART, reciclo de células. $\left(\mathrm{pH}=4,95\right.$. Temperatura $-40^{\circ} \mathrm{C}$ ).

\begin{tabular}{|c|c|c|c|c|c|c|c|}
\hline \multirow[b]{2}{*}{ Leveduras } & \multirow{2}{*}{$\begin{array}{l}\text { Fermento } \\
\text { úmido } \\
\text { inicial }\end{array}$} & \multicolumn{5}{|c|}{ Reciclo de Células } & \multirow{2}{*}{$\begin{array}{l}\text { Perda } \\
\text { celular } \\
\text { Total }\end{array}$} \\
\hline & & 1 & 2 & 3 & 4 & 5 & \\
\hline \multirow{3}{*}{ IZ 888} & ${ }^{*} 13.08$ & 13.10 & 13.58 & 12.90 & 12.46 & 12.00 & -1.08 \\
\hline & 13.16 & 13.26 & 13.40 & 12.92 & 12.60 & 11.92 & -1.24 \\
\hline & 13.00 & 12.92 & 13.00 & 12.42 & 12.10 & 11.62 & -1.38 \\
\hline \multirow[t]{2}{*}{ Média } & 13.08 & 13.09 & 13.33 & 12.75 & 12.39 & 11.85 & -1.85 \\
\hline & 13.18 & 12.78 & 12.66 & 11.96 & 11.28 & 10.58 & -2.60 \\
\hline \multirow[t]{2}{*}{$\mathrm{M}-300-\mathrm{A}$} & 13.04 & 12.72 & 12.64 & 12.00 & 11.36 & 10.60 & -2.44 \\
\hline & 13.40 & 12.72 & 12.56 & 11.78 & 11.20 & 10.50 & -2.90 \\
\hline Média & 13.21 & 12.74 & 12.62 & 11.91 & 11.28 & 10.56 & -2.65 \\
\hline
\end{tabular}

* Na tabeia são apresentados os dados originais com suas respectivas médias, não foram feitas análises estatisticas.

A levedura IZ 888 apresentou menor viabilidade celular quando comparada com M-300-A em todos os ciclos fermentativos, porem, a diminuição de massa celular foi menor para a levedura IZ 888, sendo essa linhagem sob esse aspecto aparentemente superior a M-300-A.

Os valores discutidos nesse item não foram analisados estatisticamente. 
Tabela 9. Acompanhamento do peso de fermento úmido $(\mathrm{g} / 100 \mathrm{ml})$ durante os ciclos fermentativos das leveduras IZ 888 e IZ 1904. em meio de mosto de melaço com $12 \%$ de ART. reciclo de celulas, $\left(\mathrm{pH}=4.95\right.$. Temperatura $\left.-40^{\circ} \mathrm{C}\right)$.

\begin{tabular}{|c|c|c|c|c|c|c|}
\hline \multirow{2}{*}{ Leveduras } & \multirow{2}{*}{$\begin{array}{l}\text { Fermento } \\
\text { úmido } \\
\text { inicial }\end{array}$} & \multicolumn{4}{|c|}{ Reciclo de Celulas } & \multirow{2}{*}{$\begin{array}{l}\text { Perda } \\
\text { celular } \\
\text { Total }\end{array}$} \\
\hline & & 1 & 2 & 3 & 4 & \\
\hline$== \pm====$ & $==-====$ & $====-$ & $=====$ & $====$ & $==-==$ & $=====$ \\
\hline \multirow{3}{*}{ IZ. 1904} & $* 13.86$ & 11.60 & 10.12 & 9.22 & 9.06 & -4.80 \\
\hline & 13.92 & 11.62 & 10.04 & 9.46 & 9.04 & -4.88 \\
\hline & 13.90 & 11.68 & 10.02 & 9.34 & 8.96 & -4.94 \\
\hline \multirow[t]{2}{*}{ Média } & 13.89 & 11.63 & 10.06 & 9.34 & 9.02 & -4.87 \\
\hline & 13.48 & 13.68 & 13.68 & 13.52 & 13.64 & -0.16 \\
\hline \multirow[t]{2}{*}{ IZ 888} & 13.52 & 13.76 & 13.96 & 13.88 & 14.10 & -0.58 \\
\hline & 13.40 & 13.52 & 13.64 & 13.44 & 13.58 & -0.18 \\
\hline Média & 13.47 & 13.65 & 13.76 & 13.61 & 13.77 & -0.31 \\
\hline
\end{tabular}

* Na tabela são apresentados os dados oniginais com suas respectivas médias, não foram feitas análises estatísticas.

\subsubsection{Viabilidade Celular e Brotamento}

Na tabela 10 são apresentados os resultados de viabilidade celular para as leveduras IZ 888 e M-300-A.

A levedura IZ 888 apresentou menor viabilidade celular em todos os ciclos fermentativos quando comparada com a M-300-A. As duas leveduras, apesar da diferença 
de resultados apresentaram o mesmo comportamento, ou seja, diminuição da viabilidade celular conforme evolução dos reciclos de celulas.

Em geral tem se considerado que quanto maior a temperatura maior o efeito inibitorio do etanol (NAGOD AWTTHANA et al., 1974; NAVARRO \& DURAND, 1978) e com isso há diminuição da viabilidade celular das leveduras. No presente experimento a levedura M-300-A apresentou maior produção de etanol e alta viabilidade celular quando comparada com a levedura $\mathrm{ZZ} 888$, isso mostra que a levedura M-300-A é mais tolerante as condições do experimento e ao etanol produzido.

A levedura M-300-A é conhecida por GUTIERREZ (1989) por acumular alto teor de trealose, sendo assim esse carboidrato poderia estar contribuindo para a maior proteção dessa linhagem contra fatores estressantes. principalmente a alta temperatura do presente trabalho.

Tabela 10. Viabilidade celular $(\%)$ das leveduras IZ 888 e M-300-A após fermentação em meio de mosto de melaço com $12 \%$ de ART, reciclo de células, $(\mathrm{pH}=$ 4,95. Temperatura $-40^{\circ} \mathrm{C}$ ).

\begin{tabular}{|c|c|c|c|c|c|}
\hline \multirow[b]{2}{*}{ Leveduras } & \multicolumn{5}{|c|}{ Reciclo de Células } \\
\hline & 1 & 2 & 3 & 4 & 5 \\
\hline \multicolumn{6}{|c|}{ 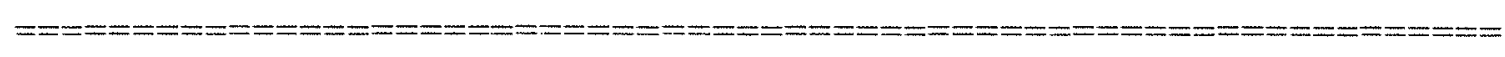 } \\
\hline IZ 888 & *88.37 & 81.70 & 72.36 & 68.46 & 59.07 \\
\hline $\mathrm{M}-300-\mathrm{A}$ & 95.36 & 92.40 & 81.95 & 77.94 & 65.23 \\
\hline \multicolumn{6}{|c|}{ 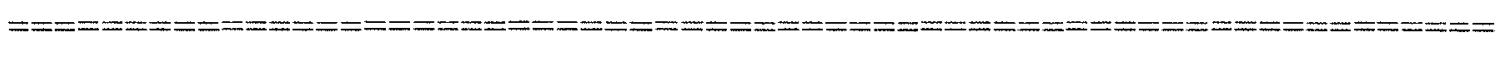 } \\
\hline \multicolumn{2}{|c|}{ d.m.s. (Leveduras) $5 \%=3.50$} & \multicolumn{4}{|c|}{ d.m.s. $($ Ciclos) $5 \%=3.67$} \\
\hline \multicolumn{2}{|c|}{$\mathrm{C.V} .=1.57 \%$} & \multicolumn{4}{|c|}{$\mathrm{C} . \mathrm{V} .=3.02 \%$} \\
\hline
\end{tabular}

* Os valores apresentados representam médias de 3 repetições. 
Va tabela 11 são apresentados os resultados de viabilidade celular para as leveduras IZ 888 e IZ 1904 .

Tabela 11. Viabilidade celular $(\%)$ das leveduras $Z 12004$ e IZ 888 apó fermentaçào em meio de mosto de melaço com $12 \%$ de ART, reciclo de células, $(\mathrm{pH}=4,95$, Temperatura $-40^{\circ} \mathrm{C}$ ).

\begin{tabular}{|c|c|c|c|c|}
\hline \multirow[b]{2}{*}{ Leveduras } & \multicolumn{4}{|c|}{ Reciclo de Células } \\
\hline & 1 & 2 & 3 & 4 \\
\hline \multicolumn{5}{|c|}{ 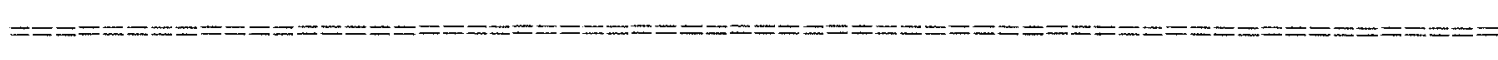 } \\
\hline IZ 1904 & *68.89 & 54.80 & 45.32 & 24.16 \\
\hline IZ 888 & 90.87 & 90.81 & 83.62 & 79.20 \\
\hline \multicolumn{5}{|c|}{ 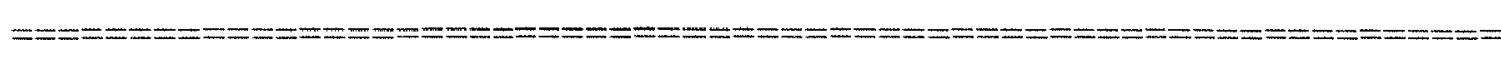 } \\
\hline \multicolumn{2}{|c|}{ d.m.s. (Leveduras) $5 \%=4.09$} & \multicolumn{3}{|c|}{ d.m.s. $($ Ciclos $) 5 \%=15.12$} \\
\hline \multicolumn{2}{|c|}{$\mathrm{C} . \mathrm{V} .=2.07$} & \multicolumn{3}{|c|}{$\mathrm{C} . \mathrm{V} .=11.10$} \\
\hline
\end{tabular}

* Os valores da tabela representam a média de 3 repetições.

A levedura IZ 888 apresentou maior viabilidade celular em todos os ciclos fermentativos quando comparada com a levedura IZ 1904.

A levedura IZ 1904 apresentou baixa viabilidade celular, principalmente nos dois últimos reciclos de células, porém, desde o inicio do experimento esta linhagem não apresentou viabilidade celular alta. Com os resultados obtidos é possivel observar que a levedura IZ 1904 não suportaria um quinto reciclo de células a $40^{\circ} \mathrm{C}$, confirmando que essa levedura não é termotolerante e sim mesófila.

O sistema utilizado nas usinas brasileiras é o de reciclo de células, com base nisso a levedura IZ 1904 não seria indicada para a utilização industrial em 
temperatura de $40^{\circ} \mathrm{C}$, devido a sua baixa viabilidade celular o que prejudicaria a reciclagem do fermento.

A levedura IZ 888 manteve viabilidade celular mais alta do que a IZ 1904. durante todos os ciclos fermentativos, demonstrando ser uma linhagem mais termotolerante e poderia ser indicada para fermentação em altas temperaturas.

Segundo SUOMALANEN \& PFAFFLI (1961) é conhecida a importância da trealose para a manutenção da viabilidade celular das leveduras. No presente trabalho foi encontrado que em meio de melaço com $12 \%$ de ART e sem reciclo de células a levedura IZ 1904 apresentou baixo acúmulo de trealose $(0.44 \%$ ) e a levedura IZ 888 apresentou maior acúmulo do carboidrato $(3.53 \%)$, havendo também diferença na viabilidade celular entre elas (Tabela 4), sendo possivel relacionar o acúmulo de trealose com a manutençào da viabilidade celular em altas temperaturas.

A partir dos resultados descritos acima é possivel explicar o baixo desempenho fermentativo da levedura $I Z$ 1904, quando comparada com a levedura IZ 888 no ensaio com reciclo de células e fazer uma associação positiva entre o acúmulo de trealose e a viabilidade celular.

A levedura M-300-A segundo GUTIERREZ (1990) apresentou acúmulo de $14.97 \%$ de trealose a $12^{\circ} \mathrm{C}$ e em meio de fermentação com $14 \%$ de ART, sendo que, apesar de não ter sido feita a dosagem desse carboidrato para essa levedura no presente trabalho é possível que a trealose seja responsável pela maior viabilidade celular obtida por essa linhagem em relação as demais leveduras testadas. PAVEK (1991) argumentou que é muito provável que em células de levedura a trealose garanta a viabilidade celular durante a germinação, jejum e desidratação, protegendo a membrana plasmática contra a autólise, o que poderia estar ocorrendo para as leveduras termotolerantes IZ 888 e M-300-A.

Na tabela 12 estão os resultados de brotamento celular para as leveduras $I Z$ 888 e M-300-A. A levedura IZ 888 apresentou menor brotamento celular em todos os ciclos fermentativos quando comparada com a levedura $\mathrm{M}-300-\mathrm{A}$.

Na tabela 13 são apresentados os resultados de brotamento para as leveduras IZ 888 e IZ 1904.

A levedura IZ 1904 apresentou maior porcentagem de brotos quando comparada com a levedura $\mathrm{IZ} 888 \mathrm{em}$ todos os ciclos fermentativos, porém a viabilidade celular da levedura IZ 1904 foi baixa, sendo que essa linhagem provavelmente possua maior número de brotos por célula. Apesar do alto brotamento da levedura IZ 1904, estes 
podem estar mortos. pois durante a contagem não foram discriminados brotos vivos $\mathrm{e}$ mortos.

Tabela 12. Brotamento celular $(\%)$ das leveduras $I Z 888$ e M-300-A após fermentaçào em meio com $12 \%$ de ART, reciclo de células. $(\mathrm{pH}=4.95$, Temperatura $\left.40^{\circ} \mathrm{C}\right)$.

\begin{tabular}{|c|c|c|c|c|c|}
\hline \multirow[b]{2}{*}{ Leveduras } & \multicolumn{5}{|c|}{ Reciclo de Células } \\
\hline & 1 & \multirow{2}{*}{$\begin{array}{c}2 \\
==\end{array}$} & \multirow{2}{*}{3} & 4 & \multirow{2}{*}{$==$} \\
\hline \multicolumn{3}{|c|}{ 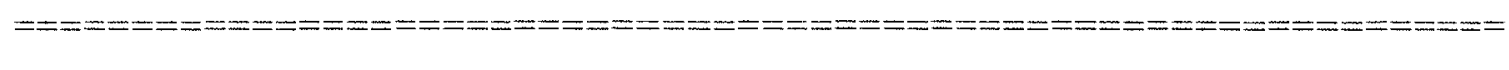 } & & & \\
\hline IZ 888 & $* 4.07$ & 6.37 & 4.30 & 2.76 & 2.08 \\
\hline $\mathrm{M}-300-\mathrm{A}$ & 10.45 & 8.64 & 7.52 & 7.41 & 2.44 \\
\hline \multicolumn{6}{|c|}{ 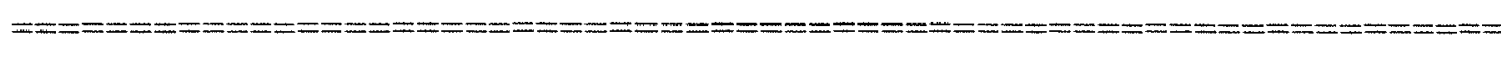 } \\
\hline \multicolumn{2}{|c|}{ d.m.s. (L eveduras) $5 \%=2.52$} & \multicolumn{4}{|c|}{ d.m.s. (Ciclos) $5 \%=3.79$} \\
\hline \multicolumn{2}{|c|}{$\mathrm{C} . \mathrm{V} .=5.41 \%$} & \multicolumn{4}{|c|}{ C.V. $=16.16 \%$} \\
\hline
\end{tabular}

* Os valores da tabela representam médias de 3 repetições. 
Tabela 13. Brotamento celular $(\%)$ das leveduras IZ 888 e IZ 1904 após fermentação em meio com 12\% de ART, reciclo de células, $\left(\mathrm{pH}=4,95\right.$, Temperatura $-40^{\circ}$ C).

\begin{tabular}{|c|c|c|c|c|}
\hline \multirow[b]{2}{*}{ Leveduras } & \multicolumn{4}{|c|}{ Reciclo de Células } \\
\hline & 1 & 2 & 3 & 4 \\
\hline \multicolumn{5}{|c|}{ 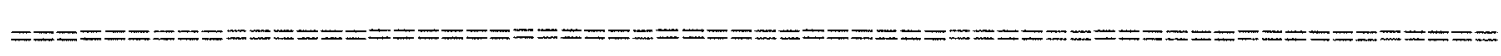 } \\
\hline IZ 1904 & *19.14 & 12.20 & 10.85 & 8.19 \\
\hline IZ 888 & 6.50 & 8.99 & 6.10 & 5.59 \\
\hline \multicolumn{5}{|c|}{ 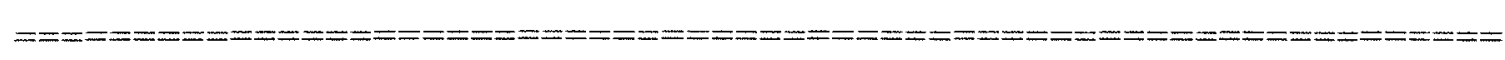 } \\
\hline \multicolumn{2}{|c|}{ d.m.s. (Leveduras) $5^{\circ} \mathrm{o}=1.87$} & \multicolumn{3}{|c|}{ d.m.s. (Ciclos) $5 \%=7.30$} \\
\hline \multicolumn{2}{|c|}{$\mathrm{C.V} .=2.99^{\circ} \mathrm{o}$} & \multicolumn{3}{|c|}{$C . V .=16.90 \%$} \\
\hline
\end{tabular}

* Os valores da tabela representam médias de 3 repetições.

\subsubsection{Etanol}

Na tabela 14 e 15 são apresentados os resultados de produção de etanol durante os reciclos de células quando a levedura IZ 888, que não é utilizada industrialmente, foi comparada com as leveduras M-300-A e IZ 1904, respectivamente, em fermentação utilizando meio de mosto de melaço com $12 \%$ de ART.

Com base nas análises estatisticas é possivel afirmar que a levedura $Z 888$ apresentou menor produção de etanol em todos os ciclos fermentativos em relação a $M$ 300-A. A levedura M-300-A provavelmente possui maior tolerância ao etanol produzido, mantendo maior viabilidade celular durante todos os ciclos fermentativos, porém ocorrendo uma queda de viabilidade nos dois últimos ciclos, sendo que as médias de produção de etanol e viabilidade celular para essa levedura são apresentadas a seguir. 


\begin{tabular}{|c|c|c|c|c|c|}
\hline & \multicolumn{5}{|c|}{ Reciclo de células } \\
\hline & 1 & 2 & 3 & 4 & 5 \\
\hline ETANOL & 5.94 & 6.49 & 6.78 & 6.78 & 6.75 \\
\hline VIABILIDADE & 95.36 & 92.40 & 81.95 & 77.94 & 65.23 \\
\hline
\end{tabular}

Tabela 14. Etanol ( $\%$ volume) produzido pelas leveduras M-300-A e IZ $888 \mathrm{em}$ meio de mosto de melaço com $12^{\circ} \%$ de ART, reciclo de células $(\mathrm{pH}=4,95$, Temperatura $-40^{\circ} \mathrm{C}$ ).

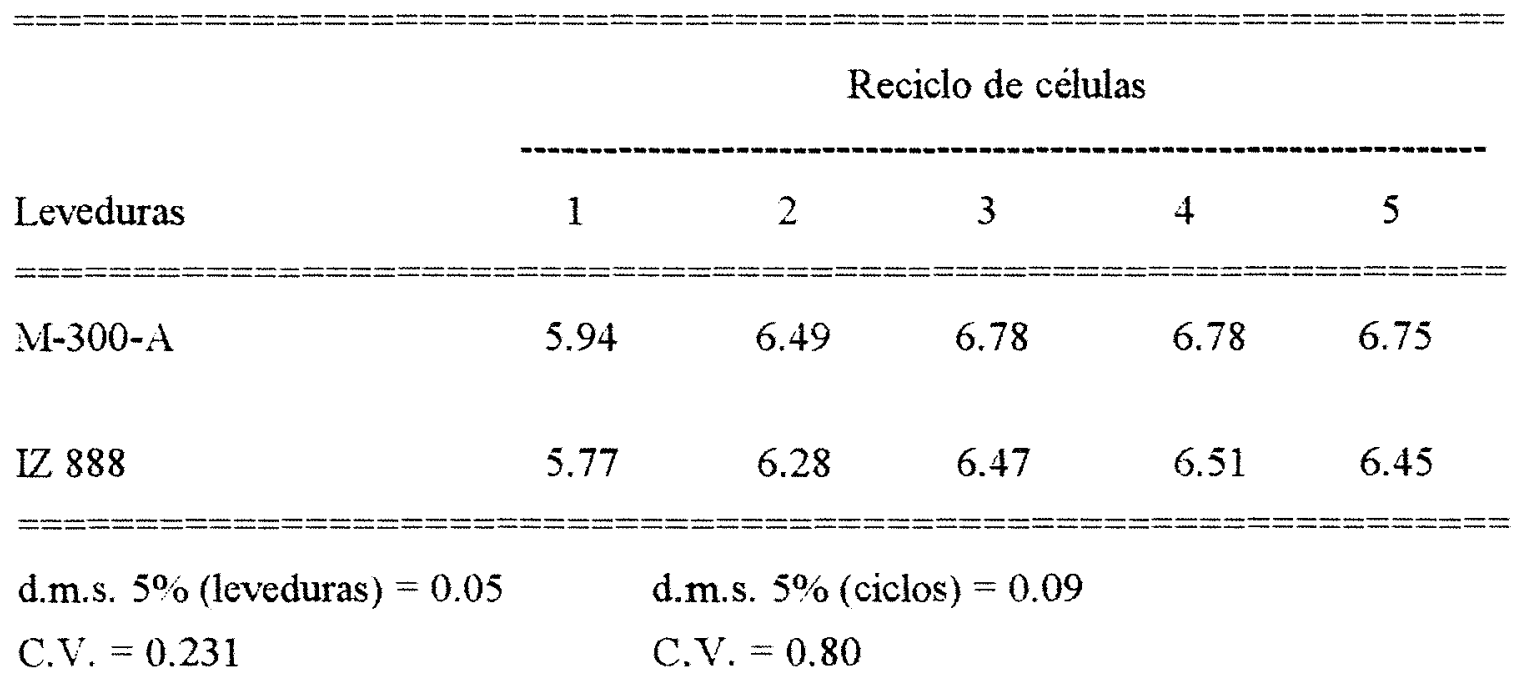

Células de leveduras quando mantidas acima da faixa ótima (acima de $35^{\circ}$ C) apresentam aumento nos seus conteúdos de ácidos graxos saturados, a fim de promover aumento na rigidez da membrana e dessa forma adquirir maior termotolerância (SLAPACK et al., 1987). 
Tabela 15. Etanol ( $\%$ volume) produzido pelas leveduras IZ 1904 e IZ $888 \mathrm{em}$ meio de mosto de melaço com $12^{\circ} \%$ de ART, reciclo de células $(\mathrm{pH}=4,95$. Temperatura $-40^{\circ} \mathrm{C}$ ).

Reciclo de células

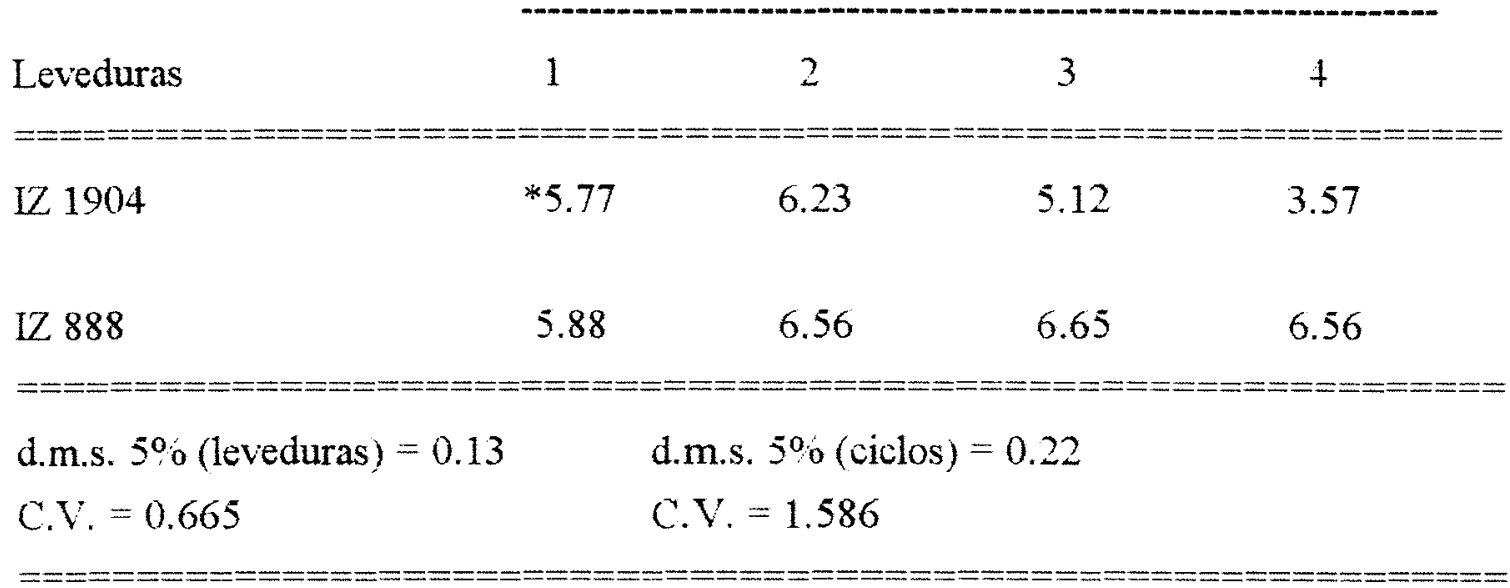

* Os valores da tabela representam a média de 3 repetições.

Com base na afirmação anterior, é possivel inferir que no presente trabalho as células de leveduras mantidas a $40^{\circ} \mathrm{C}$ sofreram adaptação de suas membranas. Quando as células foram colocadas para fermentar em meio com $12 \%$ de ART e na temperatura utilizada nesse trabalho a fermentação ocorreu de modo mais rápido, devido a alta temperatura e a difusão do etanol das células seria mais lenta em virtude da rigidez das membranas em altas temperaturas. Considerando a dificuldade de difusão do etanol com isso maior acúmulo no interior das células, haveria maior inibição da via fermentativa.

As leveduras termotolerantes não toleram bem ailtas concentrações de etanol. É possivel diminuir a intolerância das leveduras ao etanol com a adição de ácidos graxos insaturados ao meio, os quais segundo SLAPACK et al. (1987) promovem maior fluidez da membrana. permitindo uma difusão mais rápida do etanol das células para o meio. Em temperaturas mais baixas $\left(25^{\circ} \mathrm{C}\right)$ segundo o mesmo autor as células de leveduras apresentam maior proporção de ácidos graxos insaturados resultando em maior fluidez da membrana. 
Com base na discussão acima, provavelmente as leveduras termotolerantes como a M-300-A. teriam uma composição em ácidos graxos na membrana citoplasmática que permite uma maior difusão do etanol em altas temperaturas, fazendo com as celulas sejam mais tolerantes.

Foi encontrado por GUTIERREZ $(1989,1990)$ que a levedura $\mathrm{M}-300-\mathrm{A}$ uma linhagem que tem elevado acúmulo de trealose, sendo que esse carboidrato estaria protegendo a célula contra os efeitos estressantes do etanol. Os dois fatores parecem ser importantes para a produção de țanol. tanto a composição em ácidos graxos que interfere na difusão cieste metabólito, como também o acúmulo de trealose que estaria fortemente envolvido com a proteção das células contra os efeitos de desidratação causado pelo etanol.

Fermentações industriais que visam a produçăo de etanol são operadas normalmente na faixa de $25-35^{\circ} \mathrm{C}$, sendo que temperanuras mais altas, próximas ou superiores a $40^{\circ} \mathrm{C}$ tem um efeito adverso sobre essa produção (BLRROWS, 1970; HUGHES et al., 1984; KAR \& VISWANATHAN, 1985).

A levedura M-300-A é superior a IZ 888 com relação a produção geral de etanol, porém, as duas leveduras mostraram um comportamento semelhante, com aumento durante os reciclos de células e ligeira queda no último reciclo de células. As duas leveduras foram prejudicadas pela temperatura, porém a M-300-A com menos intensidade, provavelmente elas diferiram no acúmulo de trealose e em outros parâmetros, como a composição em ácidos graxos.

Algumas respostas adaptativas dos lipidios de membrana são propostas como possiveis bases bioquímicas para a tolerância ao etanol (INGRAM, 1976; SAJBIDOR \& GREGO, 1992), o que poderia estar ocorrendo com as leveduras estudadas, sendo essa resposta diferente para cada linhagem.

Quando foram analisadas as leveduras IZ 888 e IZ 1904, a primeira apresentou uma produção geral mais elevada de etanol. Não houve diferença estatisticamente significativa ao nível de $5 \%$ de significância no primeiro ciclo fermentativo entre as duas leveduras, sendo que após este ciclo a levedura IZ 888 foi superior.

A levedura IZ 1904, que é uma levedura utilizada industrialmente, apresentou baixa produção de etanol, principalmente nos dois últimos ciclos fermentativos, demonstrando que essa levedura é pouco tolerante ao etanol quando 
testada em fermentação com temperatura de $40^{\circ} \mathrm{C}$ e a produção do metabólito é prejudicada nas condições do experimento.

Segundo SAIGAL \& VISWANATHAN (1984), durante a fermentação alcoólica em usinas de climas tropicais e subtropicais a temperatura se eleva para $40^{\circ} \mathrm{C}$, sendo que a levedura IZ 1904 não seria indicada para a produção de etanol nessa temperatura. A levedura IZ 888 se mostrou mais tolerante a temperatura, ou seja a produção de etanol foi menos afetada para essa linhagem.

Apesar de não ter sido realizada analise estatistica entre os experimentos, apenas dentro de cada experimento, a levedura M-300-A apresentou uma produção de etanol superior, seguida pela IZ 888, por último a levedura IZ 1904 com menor produção deste metabólito.

De acordo com BROWN (1976) o efeito do etanol é mais fortemente observado sobre a membrana celular foi sugerido por esse autor que a inibição pelo etanol parece ser tanto um efeito geral de desidratação como inibição especifica de algumas enzimas. A levedura $\mathrm{M}-300-\mathrm{A}$, como já é conhecido pelos trabalhos de GUTIERREZ, 1989 e 1990, acumula niveis elevados de trealose, sendo que na temperatura de $40^{\circ} \mathrm{C}$ essa levedura possuiria uma alto teor de trealose capaz de protegê-la da desidratação causada pelo etanol aumentando sua tolerância a este metabólito e também protegendo contra o efeito da alta temperatura sobre a membrana celular.

A discussão acima pode explicar a diferença de comportamento entre as leveduras IZ 888 e IZ 1904 nesse ensaio com reciclo de células. A levedura IZ 1904 apresentou menor acumulo de trealose (Tabela 7 ) quando comparada com a levedura $1 Z$ 888 no ensaio sem reciclo de células, tanto em meio de fermentação com 5 e $12 \%$ de ART, sendo assim a levedura IZ 1904 estaria sendo mais prejudicada pela temperatura e pelo etanol produzido a cada ciclo fermentativo, devido ao baixo acúmulo de trealose. A levedura IZ 888 que apresentou maior acúmulo do carboidrato demonstrou melhor desempenho fermentativo nas condições do trabalho. 


\subsubsection{Glicerol}

Na Tabela 16 são apresentados os resultados de produção de glicerol para a comparação das leveduras IZ 888 e M-300-A e na Tabela 17 para as leveduras IZ 1904 e IZ 888.

Tabela 16. Glicerol (g/100ml) produzido pelas leveduras M-300-A e IZ 888 após fermentação em meio de mosto de melaço com $12 \%$ de ART, reciclo de celulas, ( $\mathrm{pH}=4,95$, Temperatura $-40^{\circ} \mathrm{C}$ ).

Reciclo de células

\begin{tabular}{|c|c|c|c|c|c|}
\hline \multirow{2}{*}{ Leveduras } & & & & & \\
\hline & 1 & 2 & 3 & 4 & 5 \\
\hline \multicolumn{6}{|c|}{ 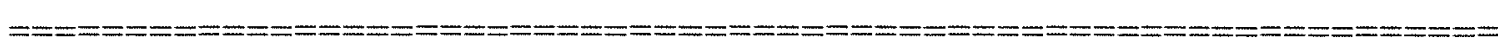 } \\
\hline IZ 888 & $* 0.60$ & 0.65 & 0.65 & 0.66 & 0.66 \\
\hline $\mathrm{M}-300-\mathrm{A}$ & 0.51 & 0.52 & 0.53 & 0.56 & 0.53 \\
\hline \multicolumn{6}{|c|}{ 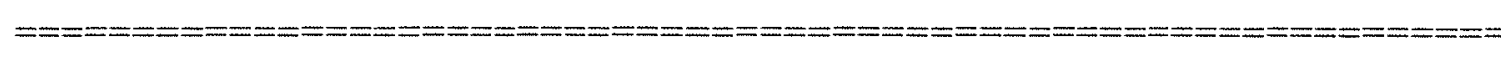 } \\
\hline d.m.s. (leveduras) $5 \%=0.02$ & \multicolumn{5}{|c|}{ d.m.s. (ciclos) $5 \%=0.01$} \\
\hline $\mathrm{C} . \mathrm{V} .=0.84$ & \multicolumn{3}{|c|}{$\mathrm{C} . \mathrm{V} .=1.50$} & & \\
\hline
\end{tabular}

* Os valores representam médias de 3 repetições.

A levedura IZ 888 apresentou maior produção de glicerol do que a levedura M-300-A em todos os ciclos fermentativos, quando estas linhagens foram comparadas.

A levedura IZ 888 juntamente com a maior produção de glicerol apresentou menor produção de etanol em relação a levedura M-300-A (Tabela 14). 
Tabela 17. Glicerol $(\mathrm{g} / 100 \mathrm{ml})$ produzido pelas leveduras IZ 888 e IZ 1904, após fermentação em meio de mosto de melaço com $12 \%$ de ART, reciclo de células, $\left(\mathrm{pH}=4,95\right.$, Temperatura $\left.-40^{\circ} \mathrm{C}\right)$.

Reciclo de células

\begin{tabular}{|c|c|c|c|c|}
\hline Leveduras & 1 & 2 & 3 & 4 \\
\hline IZ 1904 & $* 0.62$ & 0.68 & $---* *$ & $---* *$ \\
\hline IZ 888 & 0.52 & 0.53 & 0.56 & 0.62 \\
\hline
\end{tabular}

d.m.s. (leveduras) $5 \%=0.13 \quad$ d.m.s. $($ Ciclos) $5 \%=0.16$

C.V. $=0.66 \% \quad$ C.V. $=1.59 \%$

* Os valores apresentados na tabela representam a média de 3 repetições.

** Não foram determinados devido ao elevado teor de Açúcares Redutores (AR) no vinho.

A levedura $\mathrm{M}-300-\mathrm{A}$ a $34^{\circ} \mathrm{C}$ segundo verificado por GUTIERREZ (1991b) produziu $0.52(\mathrm{~g} / 100 \mathrm{ml})$ de glicerol, sendo que no presente trabalho esta levedura produziu em média $0.53(\mathrm{~g} / 100 \mathrm{ml})$. Com esses resultados, apesar de algumas diferenças experimentais é possível inferir que essa levedura não foi influenciada pela temperatura de $40^{\circ} \mathrm{C}$, com relação a produção de glicerol.

A produção de glicerol, segundo OURA (1977) estaria ocorrendo para a regeneração do $\mathrm{NAD}$, mantendo com isso o balanço redox da célula. A elevação da temperatura provoca um aumento na velocidade de reação, assim provocando um estímulo da via glicolítica. Segundo GOMES (1988) que utilizou leveduras de panificação Saccharomyces cerevisiae, a produção de glicerol seria decorrente da necessidade de equilibrar o balanço redox das células em condições que provoquem estímulo da via glicolítica. 
GOMES (1988) verificou maior produção de glicerol em células após tratamento a $25^{\circ} \mathrm{C}$ e $40^{\circ} \mathrm{C}$, sendo essa produção menor a $30^{\circ} \mathrm{C}$, sugere um mecanismo protetor do glicerol após o tratamento nas temperaturas de 25 e $40^{\circ} \mathrm{C}$.

As altas temperaturas de fermentação alteram o funcionamento de enzimas, sendo que no caso do presente trabalho a temperatura de $40^{\circ} \mathrm{C}$ poderia estar prejudicando o funcionamento da enzima desidrogenase alcoólica, principalmente para a levedura IZ 1904 no presente trabalho, sendo então que a passagem de acetaldeído para etanol poderia estar prejudicada e a regeneração do $\mathrm{NAD}$ também, este problema seria então resolvido através da via de formação do glicerol e com isso haveria regeneração do NAD.

Outro modo de explicação da formação de glicerol em fermentação a $40^{\circ} \mathrm{C}$ seria que, segundo CAZZULO \& STOPPANT (1968) a atividade enzimática da enzima piruvato descarboxilase aumenta com a temperatura, com a maior atividade dessa enzima poderia ocorrer maior formação de ácido succínico, que segundo OURA (1977), estaria relacionado com a maior formação de glicerol pela célula.

Segundo RADLER \& SCHUTZ (1982) e GUTIERREZ (1991) a linhagem da levedura utilizada é um fator que interfere na formação de glicerol, sendo que no caso do presente trabalho houve diferença entre as leveduras com relação a formação de glicerol podendo este fato estar relacionado com a linhagem de levedura utilizada, juntamente com o efeito da temperatura sobre as leveduras.

A levedura IZ 1904 apresentou maior prođução de glicerol nos dois primeiros ciclos fermentativos, quando comparada com a levedura IZ 888 (Tabela 17).

Segundo RANKNE \& BRDSON (1971) o glicerol é um constituinte importante em vinhos, porém em fermentação visando a produção de etanol ele é um subproduto indesejável, pois reduz a eficiência fermentativa como demonstrado por OURA (1977) e BRUM \& HEBEDA (1988). Segundo OURA (1977), a formação do glicerol consome $4-5 \%$ do substrato, reduzindo com isso a produção de etanol. Com base na discussão acima é possivel verificar que a levedura IZ 1904 não seria indicada para producão de etanol em temperatura de $40^{\circ} \mathrm{C}$, devido a sua alta produção de glicerol e baixa produção de etanol (Tabela 15).

Dentre as leveduras analisadas nos dois experimentos realizados nesse ensaio, apesar de não ter sido feita análise estatística entre os experimentos, a levedura M300-A apresentou menor produção de glicerol, seguida pela levedura IZ 888 e por último 
a levedura IZ 1904 que apresentou a maior produção de glicerol nas condições do trabalho.

GUTIERREZ (1991b) utilizando as leveduras IZ 1904 e M-300-A e levedura de panificação verificou que a quantidade de glicerol produzida foi fortemente influenciada pela linhagem da levedura, como também encontrado por RADLER \& SCHUTZ (1982). GUTIERREZ (1991b) encontrou ainda que, a levedura IZ 1904 obteve a menor produção de glicerol em todas as temperaturas estudadas $\left(12^{\circ} \mathrm{C}, 25^{\circ} \mathrm{C}, 34^{\circ} \mathrm{C}\right)$ em relação as demais leveduras analisadas, inclusive a M-300-A.

A partir dos resultados obtidos por GUTIERREZ (1991b), em relação a produção de glicerol pela levedura IZ 1904 é possível observar que essa levedura foi fortemente prejudicada pela alta temperatura de fermentação utilizada no presente trabalho.

A levedura IZ 1904 demonstra um bom desempenho fermentativo, produzindo baixa quantidade de glicerol em temperaturas de fermentação mais baixas (GUTIERREZ, 1989), porém, em temperaturas mais altas como a $40^{\circ} \mathrm{C}$ essa levedura tem um baixo desempenho fermentativo demonstrando que é mesófila e não termotolerante.

\subsubsection{Açúcares Redutores Residuais}

Na tabela 18 estão os resultados referentes aos açúcares redutores presentes no meio após fermentação quando foram comparadas as leveduras IZ 888 e M300-A. 
Tabela 18. Açúcares redutores residuais $(\mathrm{g} / 100 \mathrm{ml}) \mathrm{em}$ meio de mosto de melaço com $12 \%$ de ART após fermentação com as leveduras IZ 888 e M-300-A, reciclo de células, $\left(\mathrm{pH}=4,95\right.$, Temperatura $\left.-40^{\circ} \mathrm{C}\right)$.

\begin{tabular}{|c|c|c|c|c|c|}
\hline \multirow[b]{2}{*}{ Leveduras } & \multicolumn{5}{|c|}{ Reciclo de células } \\
\hline & 1 & 2 & 3 & 4 & 5 \\
\hline \multicolumn{6}{|c|}{ 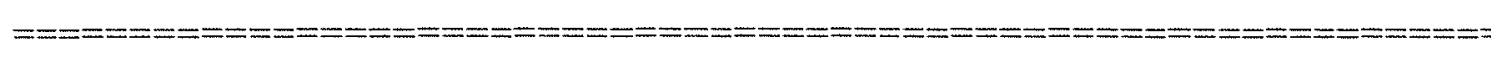 } \\
\hline IZ 888 & $* 0.42$ & 0.55 & 0.47 & 0.54 & 0.59 \\
\hline $\mathrm{M}-300-\mathrm{A}$ & 0.50 & 0.55 & 0.48 & 0.53 & 0.59 \\
\hline \multicolumn{6}{|c|}{ 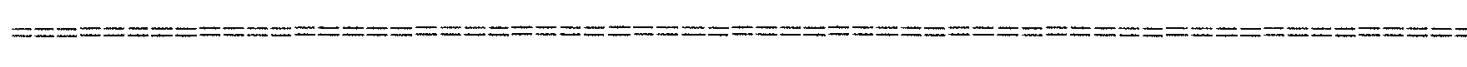 } \\
\hline d.m.s. (leveduras) $5 \%=0.02$ & \multicolumn{5}{|c|}{ d.m.s. $($ ciclos) $5 \%=0.009$} \\
\hline C.V. $=1.13$ & \multicolumn{3}{|c|}{ C.V. $=1.04$} & & \\
\hline
\end{tabular}

* Os valores da tabela representam a média de 3 repetições.

As leveduras IZ 888 e M-300-A quando analisadas estatisticamente não mostraram diferença significativa ao nível de $5 \%$ de significância, com relação ao açúcar redutor presente no meio fermentado, sendo assim a quantidade de açúcar consumida durante a fermentação é a mesma pelas duas leveduras.

Apesar de não ter sido detectada diferença na quantidade de açúcar redutor presente no meio, as duas leveduras estudadas diferiram com relação a produção de etanol (Tabela 14) sendo que levedura M-300-A teve maior produção deste metabólito, com menor produção de glicerol (Tabela 16). A levedura IZ 888 apresentou menor produção de etanol com maior produção de glicerol.

Com os resultados obtidos é possível inferir que a levedura $\mathrm{M}-300-\mathrm{A}$ possui um desempenho fermentativo superior a levedura IZ 888, pois houve maior conversão do açúcar presente no meio em etanol, com menor formação de subprodutos, como o glicerol. A temperatura pode estar influenciando a diferença de comportamento entre essas duas leveduras, assim como o teor de trealose acumulado por cada linhagem. 
PEISNO (1986) verificou que em meio de fermentação com $12.3 \%$ de ART e em temperatura de $30^{\circ} \mathrm{C}$ a levedura $\mathrm{M}-300-\mathrm{A}$ mantinha uma viabilidade celular acima de $80 \%$, sendo que no presente ensaio a concentração do meio de fermentação foi de $12 \%$ de ART e a temperatura de $40^{\circ} \mathrm{C}$ e essa linhagem manteve viabilidade celular acima de $80 \%$ até o terceiro reciclo de células.

$\mathrm{Na}$ tabela 19 estão apresentados os dados referentes aos açúcares redutores presente no meio fermentado quando foram comparadas as leveduras IZ 888 e IZ 1904.

A levedura IZ 888 apresentou de modo geral menor quantidade de $A R$ presente no meio fermentado e a levedura IZ 1904 apresentou maior quantidade de açúcares redutores no meio após fermentação. As duas leveduras não diferiram estatisticamente ao nivel de $5 \%$ de significância com relação ao AR nos dois primeiros ciclos fermentativos, porém nos dois últimos ciclos fermentativos a levedura $I Z 1904$ apresentou elevado valor de $A R$, baixa produção de etanol, alta produção de glicerol e baixa viabilidade celular, provavelmente havendo predominância de morte celular neste dois últimos ciclos devido a temperatura utilizada de $40^{\circ} \mathrm{C}$ o que não ocorreu para a levedura IZ 888.

A levedura $\mathrm{IZ} 888$ apresentou um desempenho fermentativo superior a levedura IZ 1904 em alta temperatura de fermentação com relação a conversão do açúcar presente no meio em etanol, sendo assim a levedura IZ 888 seria mais indicada para a utilização industrial em altas temperaturas, devido a sua maior conversão do açúcar presente no meio em etanol com menor desvio para a formação de glicerol.

GOMES (1988) utilizou leveduras de panificação Fleischmann, sendo estas submetidas a altas temperaturas e após o tratamento colocadas para fermentar. Esse autor observou maior quantidade de AR obtida no vinho quanto maior a temperatura utilizada no tratamento e inferiu ser devido a alteração da permeabilidade da membrana celular em relação ao etanol, o que pode ter ocorrido para a levedura IZ 1904 no presente trabalho já que o teor de AR encontrado no meio fermentado foi maior para essa levedura.

A linhagem IZ 1904 deve ter sido prejudicada pela temperatura ocorrendo alteração da permeabilidade de sua membrana, provavelmente devido ao baixo acúmulo de trealose por essa levedura, já constatado em fermentação sem reciclo de células. 
Tabela 19. Açúcares redutores residuais $(\mathrm{g} / 100 \mathrm{ml})$ em meio de mosto de melaço com $12 \%$ de ART após fermentação com as leveduras IZ 888 e IZ 1904, reciclo de células. $\left(\mathrm{pH}=4,95\right.$, Temperatura $\left.-40^{\circ} \mathrm{C}\right)$.

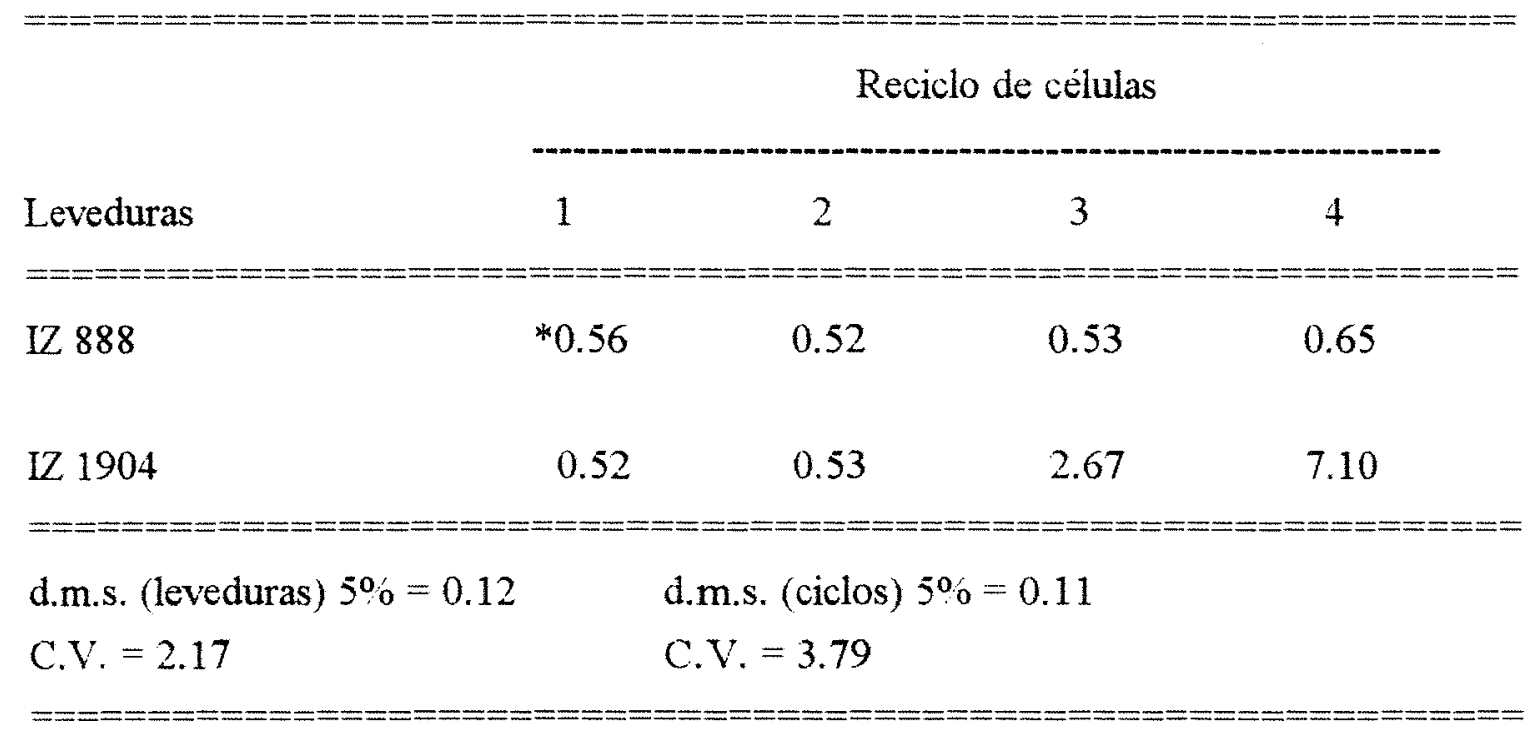

* Os valores da tabela representam a média de 3 repetições. 


\section{CONCLUSÕES}

Os resultados obtidos em escala de laboratório com fermentação a $400^{\circ} \mathrm{C}$ com as leveduras analisadas permitem concluir que:

- Dentre todas as leveduras testadas no experimento sem reciclo de células e em meio de fermentação a $5 \%$ e $12 \%$ de ART as linhagens IZ 888 e IZ 1831 foram as linhagens que apresentaram maior acúmulo de trealose. juntamente com alta viabilidade celular, entretanto a $\mathrm{ZZ} 888$ apresentou tendência para maior viabilidade e brotamento.

- Em meio de mosto de melaço a 5\% de ART e sem reciclo de células não foi possivel relacionar acúmulo de trealose com viabilidade celular, porém em meio com $12 \%$ de ART, as leveduras com maior acúmulo de trealose apresentaram viabilidade celular mais elevada.

- Para a levedura IZ 1904 em temperatura a $40^{\circ} \mathrm{C}$ houve predominância de morte celular no ensaio com reciclo de células, pois esta linhagem apresentou baixa viabilidade celular, baixa produção de etanol e alta de glicerol, aita concentração de AR no meio após fermentação.

- A levedura selecionada no presente trabalho (IZ 888) quando comparada com as leveduras industriais apresentou melhor comportamento do que a IZ 1904 e foi inferior a $\mathrm{M}-300-\mathrm{A}$.

- Não se pode afirmar que a trealose seja o único fator a explicar a maior tolerância a altas temperaturas nas leveduras estudadas. 
6. REFERENCIAS BIBLIOGRÁFICAS

ALTERTHUM, F. \& CRUZ, M.R.M.G. Aumento do rendimento da fermentaçào alcoólica pela adição de óleo de soja. Revista de Microbiologia, São Paulo, 18(1):52-7, 1987.

AMIN, G.; STANDAERT, P.; VERACHTERT, H. Effects of metabolic inhibition on the alcoholic fermentation by several yeasts in batch or in immobilizad cell systems. Applied Microbiology and Biotechnology, Berlin, 19:91-9, 1984.

AMORM, H.V.: ZAGO, E.A.; OLIVEIRA, A.I. Novos métodos para o controle da fermentação alcoólica. São Paulo, Sociedade Brasileira de Microbiologia, 1982. $58 \mathrm{p}$.

ANDREANSEN, A.A. \& STIER, J.B. Anaerobic Nutrition of Saccharomyces cerevisiae. Journal Cellular and Comparative Physiology, Philadelphia, 43:271$80,1954$.

ARTHUR, H. \& WATSON, K. Thermal adaptation in yeast: growth temperatures, membrane lipid, and cytochrome composition of phychrophilic, mesophilic, and thermophilic yeasts. Journal of Bacteriology, Baltimore, 128(1):56-68, 1976.

ATTFIELD, P.V. Trehalose accumulates in Saccharomves cerevisiae during exposure to agents that induce heat shock response. FEBS Letters. Amsterdam. 225(12):259-63, 1987.

BARTON, J.K.; HOLLANDER, J.A.D.; HOPFIELD, J.J.; SHULMAN, R.G. ${ }^{13}$ C Nuclear magnetic resonance study of trehalose mobilization in yeast spores. Journal of Bacteriology, Baltimore, 151(1):177-85, 1982. 
BEAVEN. J.M.; CARPENTIER, C.: ROSE, A.H. Production and tolerance of ethanol in relation to phospholipid fatty-acid composition in Saccharomyces cerevisiae NCYC 431. Journal of General Microbiology, London. 128:1447-55, 1982.

BENDOVA, O.; RICHTER, V.; JANDEROVA, B.; HÄUSLER. J. Identification of industrial yeast strains of Saccharomyces cerevisiae by fatty acid profiles. Applied Microbiology and Biotechnology, Berlin, 35:810-2, 1991.

BLOOMFIELD. D.K. \& BLOCH, K. The formarion of $\Delta^{9}$ - unsaturated fatty acids. Journal of Biological Chemistry. Baltimore. 235(2):337-45, 1960.

BRN, M. Transketolase: clinical aspects. In: COLOWTCK, S.P. \& K.APLAN, N.O., ed. Methods in enzymology. New York. Academic Press, 1966. v.9., p.506-14.

BROWN, A.D. Microbial water stress. Bacteriological Reviews, Baltimore, 40:803-46, 1976.

BROWN. C.M. \& ROSE, A.H. Fatty-acid composition of Candida utilis as affected by growth temperature and dissolved-oxygen tension. Journal of Bacteriology, Baltimore, 99(2):371-8, 1969.

BROWN. W.S. \& OLNER, S.G. The effect of temperature on the ethanol tolerance of the yeast Saccharomyces wvarum. Biotechnology Letters. Kew, 4(4):269-79, 1982.

BRUMM, P.I. \& HEBEDA. R.E. Glycerol production in industrial alcohol fermentations. Biotechonology Letters, Kew, 10(9):677-82, 1988.

BLRROW, S. Baker's yeast. In: ROSE, A.H. \& HARRISON, J.S. ed. The yeasts. London, Academic Press, 1970. v.3: Yeast technology, cap. 7, p.349-413.

CASEY, G.P.; MAGNUS, C.A.; NGLEDEW, W.M. High-growth brewing: effects of nutrition on yeast composition, fermentation ability, and alcohol production. Applied Enviromental Microbiology, Baltimore. 48(3):639-46, 1984. 
CAZZULO. J.J. \& STOPPANI, A.O.M. The regulation of yeast pyruate carboxilase by acetyl-coenzyme A and L-Aspartate. Archives of Biochemistry and Biophysics. New York. 127:563-7, 1968.

CROWE, J.H.; CROWE, L.M.: CHAPMAN, D. Presentation of membranes in anhydrobiotic organisms. The role of trehalose. Science, Washington, 223:701-3, 1984.

CROWE. I.H.; PANEK, A.D.; CROWE, L.M.; PANEK, A.C.; ARAUJO, P.S. Trehalose transport in yeast cell. Biochemistry International, Marrickville. 24(4):721-30. 1991.

CROWE, L.M.; MOURADIAN, R.; CROWE, J.H.; JACKSON, S.A.; WOMERLEY. C. Effect of carboydrates on membrane stability at low water activities. Biochimica et Biophysica Acta, Amsterdam, 769:141-50, 1984.

D'AMORE, T. \& STEWART, G.G. Ethanol toleronce of yeast. Enzyme and Microbial Technology, Guildford, 9:322-30, 1987.

D'AMORE, T.; CRUMPLEN, R.; STEWART, G.G. The involvement of trehalose in yeast stress tolerance. Journal of Industrial Microbiology, Amsterdam, 7(3):191$5,1991$.

DE MARTIN, V.F. Efeito da remoção de células sobre o rendimento da fermentação alcoólica por leveduras. Piracicaba, 1987. 190p. (Mestrado - Escola Superior de Agricultura "Luiz de Queiroz" (USP).

DE VIRGILIO, C.; PIPER, P.; BOLLER, T.; WIEMKEN, A. Acquisition of thermotolerance in Saccharomvces cerevisiae without heat shock protein HSP 104 and in the absence of protein synthesis. FEBS Letters, Amsterdam, 288(1:2):86$90,1991$. 
DOMBEK. K.M. \& NGRAM. L.O. Magnesium limitation and its role in apparent toxicity of ethanol during yeast fermentation. Applied Environmental Microbiology, Baltimore, 52(5):975-81, 1986.

ELBEN, A.D. The metabolism of $\alpha$-Trehalose. Advances in Carbohydrate Chemistry, New York, 30:227-56, 1974.

ELELTHERIO. E.C.A.; DE ARAÚJO, P.S.; P.ANEK, A.D. Role of the trehalose carrier in dehydration resistance of Saccharomyces cerevisiae. Biochimica et Biophysica Acta. Amsterdam, 1156:263-6, 1993.

FARREL, J. \& ROSE, A. Temperatures effect on microorganisms. Annual Review of Microbiology, Palo Alto, 21:101-20, 1967.

FEOFILOVA, E.P.; GRYAZNOVA, M.V.; SADOVOVA, N.V. Ability of Mannitol and Trehalose to enhance resistance of mycelial fungi to thermal factors. Applied Biochemistry and Microbiology, New York, 25(5):593-9, 1989.

GAO. C. \& FLEET, G.H. The effect of temperature and $\mathrm{pH}$ on the ethanol tolerance of the wine yeasts, Saccharomyces cerevisiae. Candida stellata and Kloeckera apiculata. Journal Applied Bacteriology, Reading, 65:405-9, 1988.

GILL, C.O. \& SUISTED, J.R. The effects of temperature and growth rate on the proportion of unsaturated fatty-acids in bacterial lipids. Journal of General Microbiology, London, 104:31-6, 1978.

GOMES. E. Efeito do tratamento ácido da levedura Saccharomyces cerevisiae na fermentação alcoólica. Piracicaba, 1988. 206p. (Mestrado - Escola Superior de Agricultura "Luiz de Queiroz" (USP).

GOMES, F.P. Curso de estatística experimental. 12.ed. São Paulo, Nobel, 1987. 467p.

GRAY, W.D. Studies on the alcohol tolerance of yeasts. Journal of Bacteriology; Baltimore, 42:561-74, 1941. 
GRBA. S.; OLRA. E.; SUOMALANEN. H. On the formation of glycogen and trehalose in baker's yeast. European Journal Applied Microbiology and Biotecnology, Berlin. 2:29-37, 1975.

GUTIERREZ. L.E. Efeito de adição de sulfato de amônio sobre a produção de ácido succinio durante a fermentação alcoólica. Anais da Escola Superior de Agricultura "Luiz de Queiroz", Piracicaba. 45, 1988.

GUTIERREZ. L.E. Estudo comparativo da fermentação alcoólica por linhagens de Saccharomvces cerevisiae e Saccharomvces uvamum. Piracicaba. 1989. 160p. (Livre-docencia - Escola Superior de Agricultura "Luiz de Queiroz"/USP).

GLTIERREZ, L.E. Acúmulo de trealose em linhagens de Saccharomyces cerevisiae durante fermentação alcoólica. Anais da Escola Superior de Agricultura "Luiz de Queiroz". Piracicaba, 47(pt. 2):597-608, 1990.

GUTIERREZ, L.E. Composição em acidos graxos e viabilidade celular em Saccharomyces cerevisiae. STAB. Açúcar, Álcool e Subprodutos, Piracicaba. 9(6)31-4. jul./ag., 1991 a.

GUTIERREZ, L.E. Produção de glicerol por linhagens de Saccharomyces durante fermentaçào alcoólica. Anais da Escola Superior de Agricultura "Luiz de Queiroz". Piracicaba, 48:55-69, $1991 \mathrm{~b}$.

GUTIERREZ. L.E.; ANNICHINO, A.V.K.O; LUCATTI. L.; SILVA, S.B.L. Aumento da produção de etanol a partir de melaço de cana-de-açúcar pela adição de benzoato. Anais da Escola Superior de Agricultura "Luiz de Queiroz", Piracicaba, 48:1-21, 1991.

HACKING, A.J; TAYLOR, J.W.F.; HANAS, C.M. Selection of yeast able to produce ethanol from queose at $40^{\circ} \mathrm{C}$. Applied Microbiology Biotechnology, Berlin, 19:361-3, 1984 . 
HOPPE, G.K. \& HANSFORD, G.S. Ethanol inhibition of continuous anaerobic yeast growth. Biotechnology Letters, Kew, 4(1):39-44, 1982.

HOTTIGER, T.; BOLLER, T.; WIEMKEN, A. Rapid changes of heat and desiccation tolerance correlated with changes of trehalose content in Saccharomyces cerevisiae cells subjected to temperature shifts. FEBS Letters, Amsterdam, 220(1):113-5, 1987a.

HOTTIGER. T.; SCHMUTZ, P.; WIEMKEN, A. Heat-induced accumulation and futile cycling of trehalose in Saccharomyces cerevisiae. Journal of Bacteriology, Baltimore, 169(12):5518-22, $1987 \mathrm{~b}$.

HUGHES, D.B.; TUDROSZEN, N.J.; MOYE, C.J. The effect of temperature on the kinetics of ethanol production by a thermotolerant strain of Kluveromyces marxianus. Biotechnology Letters, Melbourne, 6(1):1-6, 1984.

HUNTER, K. \& ROSE, A.H. Lipid composition of Saccharomyces cerevisiae as influenced by growth temperature. Biochimica et Biophysica Acta, Amsterdam, 260:639-53, 1972.

IDRIS EL SHERTH, E.T.A. \& BERRY, D.R. Effect of temperature on the protein and nucleic acid content of thermotolerant yeasts. Biotechnology Letters, Kew, 2(3):105-10, 1980.

NGRAM, L.O. Adaptation of membrane lipids to alcohols. Journal of Bacteriology, Baltimore, 125(2):670-8, 1976.

KAR, R. \& VISWANATHAN, L. Ethanolic fermentation by thermotolerant yeast. Journal of Chemical Technology and Biotechnology, London, 35B:235-8, 1985.

KELLER. F; SCHELLEMBERG, M.; WIEMKEN, A. Localization of trehalose in vacuoles and of trehalose in the cytosol of yeast (Saccharomyces cerevisiae). Archives of Microbiology, Berlin, 131:298-301, 1982. 
KOCK, E.M. \& KOCK, F.C. Presence du trehalose dans la levure. Science, Washington, $61: 570-2,1925$.

KROUWEL, P.G. \& BRABER, L. Ethanol production by yeast at supraoptimal temperatures. Biotechnology Letters, Kew, 1(10):403-8, 1979.

LALUCE, C; PALMIERI, M.C; CRUZ, C.L. Growth and fermantation characteristics of new selected strains of Saccharomyces at high temperatures and high cell densities. Biotechnology and Bioengineering, New York, 37:528-36. 1990.

LEGMANN, R.N. \& MARGALITH. P. A comparative study of the lipid composition of yeasts with diferent fermentative capacities. Applied Microbiology Biotechnology, Berlin, 26:49-54, 1987.

LILLE, S.H. \& PRINGLE, J.R. Preserve carbohydrate metabolism in Saccharomyces cerevisiae responses to nutrient limitation. Journal of Bacteriology, Baltimore, 143: $1384-94,1980$.

LOW, C. \& PARKS, L.W. Sterol and phospholipid acyl chain alterations in Saccharomyces cerevisiae secretion mutants as a function of temperature stress. Lipids, Chicago, 22(10):715-20, 1987.

McALISTER, L. \& FINGELSTEIN, D.B. Heat shock proteins and thermal resistance in yeast. Biochemical and Biophysical Research Communications, Duluth, 93(3):819, 1980.

MISHRA, P. \& PRASAD, R. Relationship between ethanol tolerance and fatty acyl composition of Saccharomyces cerevisiae. Applied Microbiology and Biotechnology, Berlin, 30:294-8, 1989.

NABAIS, R.C.; CORREIA. I.S.; VIEGAS, C.A.; NOVAIS, J.M. Influence of calcium ion on ethanol tolerance of Saccharomyces bayanus and alcoholic fermentation by yeasts. Applied Environmental Microbiology, Baltimore, 54(10):2439-46, 1988. 
NAGODAWTTHANA, T.W.; CASTELLANO, C.; STENKRAUS, K.H. Effect of dissolved oxygen, temperature, initial cell count, and sugar concentration on the viability of Saccharomvces cerevisiae in "rapid fermentation". Applied Microbiology, Baltimore, 28(3):383-91, 1974.

NAVARRO, J.M. \& DURAND, G. Fermentation alcoolique: influence de la temperature sur l'accumulation d'alcool dans les cellules de levure. Annales de Microbiologie, Paris, 129B:215-21, 1978.

NORDSTROM. K. Yeast growth and glycerol formation. Acta Chemica Scandinavica, Copenhagen, 20(4):1016-25, 1966.

NOVAK, M.; STREHAIANO, P.; MORENO, M.; GOMA, G. Alcoholic fermentation: on the inhibitory effect of ethanol. Biotechnology and Bioengineering, New York, 203:201. 1981 .

OOSTHUIZEN, A.; KOCK, J.L.F.; BOTES, P.J.; LATEGAN, P.M. The long-chain fatty acid composition of yeasts used in the brewing industry. Applied Microbiology Biotechnology, Berlin, 26:55-60, 1987.

OLRA, E. Reaction products of yeast fermentation. Process Biochemistry, London, 12:19-35, 1977 .

PANCHAL, C.J.; PEACOCK, L.; STEWART, G.G. Incresead osmotolerance of genetically modified ethanol producing stains of Saccharomyces sp. Biotechnology Letters, Kew, 4(10):639-44, 1982.

PANEK, A.D. Energy requirements for trehalose synthesis. Ciência e Cultura, São Paulo, 23(1):75-9, 1971.

PANEK, A.D. Trehalose synthesis during starvation of baker's yeast. European Journal Applied Microbiology, Berlin, 2(1):39-46, 1975. 
PANEK, A. Storage carbohydrates. In: ROSE. A.H. \& STWART HARRISON, J. ed. The yeasts. Academic Press, 1991. v.4, Yeast organelles, cap.13, p.655-679.

PANEK, A.C.; MANSURE, J.J.A.; PASCHOALIN, M.F.; PANEK, D. Regulation of trehalose metabolism in Saccharomyces cerevisiae mutants during temperature shifts. Biochimie, Paris, 72:77-9, 1990.

PANEK, A.D.; PANEK, A.C.; BERNARDES, E. Does trehalose play a role in yeast cells under stress? In: LEOPOLD, A.C., ed. Membranes metabolism and dry organisms. New York, Cornell Univ. Press, 1986. p.123-42.

PARADA, G. \& ACEVEDO, F. On the relation of temperature and RNA content to the specific growth rate in Saccharomyces cerevisiae Biotechnology and Bioengineering, New York, 25:2785-8, 1983.

PASCUAL, C.; ALONSO, A.; GARCIA, I.; ROMAY, C.; KOTYK, A. Effect of ethanol on glucose transport, key glycolytic enzymes, and proton extrusion in Saccharomyces cerevisiae Biotechnology and Bioengineering, New York, 32:374-8, 1988.

PEISINO, G. Avaliação de leveduras industriais em diferentes condições de fermentação alcoólica. Piracicaba, 1986. 140p. (Mestrado - Escola Superior de Agricultura "Luiz de Queiroz"/USP).

PIERCE, J.S. Institute of brewing: analysis comittee measurement of yeast viability. Journal Institute Brewing, London, 76(5):442-3, 1970.

QUASTEL, J.H. Membrane structure and function. Science, Wasiington, 158:146-60, 1967.

RADLER, F. \& SCHUTZ, H. Glycerol production of various strains of Saccharomyces. American Journal of Enology and Viticulture, Davis, 33(1):36-40, 1982. 
RANKNE, B.C. Formation of alpha-ketoglutaric acid by wine yeasts and its enological significance. Journal of the Science and Agriculture, Barking, 19:624-27, 1968.

RANKINE, B.C.\& BRIDSON, A. Glicerol in Australian wines and factors influencing its formation. American Journal of Enology and Viticulture, Davis, 22:6-12, 1971.

RATTRAY, J.B.M.; SCHIBECI, A; KIDBY, D.K. Lipids of yeasts. Bacteriological Reviews, Baltimore, 39(3):197-231, 1975.

SAIGAL, D. \& VISWANATHAN, L. Effect of oils and fatty acids on molasses fermentation by distiller's yeast. Enzyme and Microbial Technology, Guildford, $6(2): 78-80,1984$.

SAIGAL, D. \& VISWANATHAN, L. Effect of oils and fatty acids in the tolerance of distiller's yeast to alcohol and temperatures. International Sugar Journal, London. 85(1017):266-9, 1983.

SAJBIDOR, J. \& GREGO, J. Fatty acid alterations in Saccharomyces cerevisiae exposed to ethanol stress. FEMS Microbiology Letters, Amsterdan, 93:13-6, 1992.

SANTOS, M.N.G. Seleção de leveduras termotolerantes para a produção de etanol. Viçosa, 1988. 45p. (M.S. - Universidade Federal de Viçosa).

SLAPACK, G.E.; RUSSEL, I.; STEWART, G.G. Thermophilic microbes in ethanol production. Boca Raton, CRC Press, 1987. 186p.

STOKES, J.L. Influence of temperature on the growth and metabolism of yeasts. In: ROSE, A.H. \& HARRISON, J.S., ed. The yeasts. London, Academic Press, 1971. v.2: Physiology abd Biochemistry of Yeasts, p.119-34.

SUOMALANEN, H. \& PFAFFLI, S. Changes in the carbohydrate reserves of baker's yeast during growth and on standing. Journal Institute Brewing, London, 67:24954, 1961. 
SULTARI, M.; LIUKKONEN. K.; LAAKSO, S. Temperature adaptation in yeasts: the role of fatty acids. Journal fo General Microbiology, London, 136:1469-74, 1990.

SZCZODRAK, I. \& TARGONSKI, Z. Selection of thermotolerant yeast strains for simultaneous saccharification and fermentation of cellulose. Biotechonology and Bioengineering, New York, 31:300-3, 1988.

THEVELEN, J.M. Regulation of trehalose mobilization in fungi. Microbiological Reviews, Washington, 48(1):42-59, 1984.

THOMAS, D.S. \& ROSE, A.H. Inhibitory effect of ethanol on growth and solute accumulation by Saccharomyces cerevisiae as affected by plasma-membrane lipid composition. Archives of Microbiology, Berlin, 122:49-55, 1979.

THOMAS, D.S.; HOSSACK, J.A.; ROSE, A.H. Plasma membrane lipid composition and ethanol tolerance in Saccharomyces cerevisiae. Archives of Microbiology, Berlin, 117:239-45, 1978.

TREVELYAN, W.E. \& HARRISON, J.S. Studies on yeast metabolism. the trehalose content of baker's yeast during anaerobic fermentation. Biochemical Journal, London, 62:177-83, 1956.

WADA, M.; KATO, J.; CHIBATA, J. Continuous production of ethanol in high concentration using immobilized growing yeast cells. European Journal Applied Microbiology and Biotecnology, Berlin, 11:67-71, 1981.

WATSON, K. Temperature relations. In: ROSE, A.H. \& HARRISON, I.S. ed. The yeasts. London, Academic Press, 1970. v.3: Yeast technology, v.2. p.41-71.

WATSON, $\mathrm{K}$. Unsaturated fatty acids but not ergosterol is essential for high ethanol production in Saccharomyces. Biotechnology Letters, Kew, 4(6):397-402, 1982.

WATSON, K. \& CAVICCHIOLI, R. Acquisition of ethanol tolerance in yeast cells by heat shock. Biotechnology Letters, Kew, 5(10):683-8, 1983. 
WIENKEN. A. Trehalose in yeast, stress protection rather than reserve carbohydrate. Antonie van Leuwenhoek, Amsterdan, 58:209-17, 1990.

WILSON, K. \& McLEOD, B.J. The influence of conditions of growth on the endogenous metabolism of Saccharomyces cerevisiae: effect on protein, carbohydrate, sterol and fatty acid content and on viability. Antonie van Leuwenhoek. Amsterdan, 42:397-410, 1976.

WNKLER, K.; KIENLE, I; BURGET, M.; WAGNER, J.C; HOLZER, N. Metabolic regulation of the trehalose content of vegetative yeast. FEBS Letters, Amsterdan, 291:269-72, 1991.

ZAGO, E.A. Efeito da concentração de N, P, Mg, Mn e Zn na multiplicação de leveduras industriais. Piracicaba, 1982. 125p. (Doutorado - Escola Superior de Agricultura "Luiz de Queiroz", (USP).

ZAGO, E.A.; AMORIM. H.V.; OLIVEIRA, A.J.; BASSO, L.C. Métodos analíticos para o controle da produção de álcool. Centro de Biotecnologia Agricola, Piracicaba, 1989. 144p. 
7. APÊNDICE

ANÁLISES ESTATÍSTICAS 
TABELA 1. Dados originais e análise da variância do teor de trealose $(\%)$ do experimento 1 para leveduras após fermentação em mosto de melaço com $5 \%$ de ART, baixa concentração de inóculo e sem reciclo de células.

\begin{tabular}{|c|c|}
\hline Leveduras & TREALOSE $(\%)$ \\
\hline \multicolumn{2}{|c|}{ 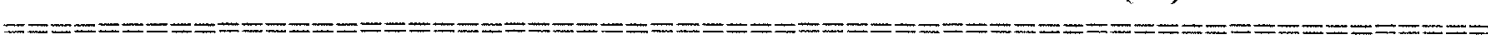 } \\
\hline \multirow{4}{*}{ IZ 222} & 2.87 \\
\hline & 2.54 \\
\hline & 2.24 \\
\hline & 2.71 \\
\hline \multirow{3}{*}{ IZ 270} & 1.32 \\
\hline & 0.63 \\
\hline & 1.28 \\
\hline \multirow{4}{*}{ IZ 1831} & 5.01 \\
\hline & 5.29 \\
\hline & 5.44 \\
\hline & 9.78 \\
\hline \multirow{4}{*}{ IZ 1834} & 0.45 \\
\hline & 0.29 \\
\hline & 0.62 \\
\hline & 0.34 \\
\hline
\end{tabular}

QUADRO DA ANÁLISE DA VARIÂNCLA

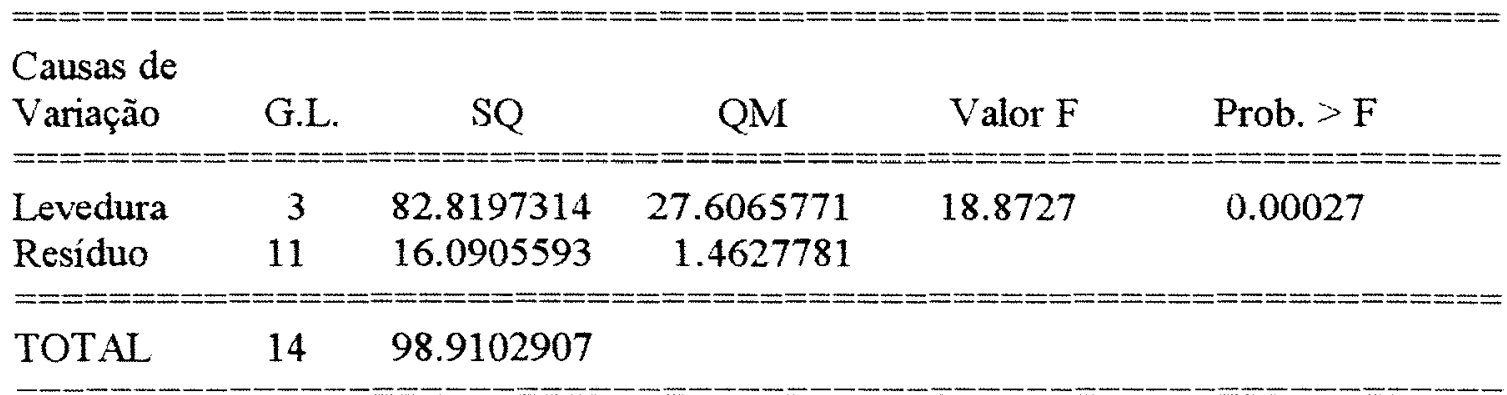

Média Geral $=2.720667$

Coeficiente de variação $=44.454 \%$ 
TABELA 2. Dados originais e análise de variancia do teor de trealose (\%) do experimento 2 para leveduras após fermentação em mosto de melaço com $5 \%$ de ART, baixa concentração de inóculo e sem reciclo de células.

\begin{tabular}{|c|c|}
\hline$========+==+=====$ & $\begin{array}{l}\text { TREALOSE }(\%) \\
=======================\end{array}$ \\
\hline IZ 888 & $\begin{array}{l}2.32 \\
2.97 \\
1.80\end{array}$ \\
\hline IZ 878 & $\begin{array}{l}0.58 \\
0.67 \\
0.47\end{array}$ \\
\hline IZ 879 & $\begin{array}{l}1.12 \\
1.08 \\
1.01\end{array}$ \\
\hline IZ 860 & $\begin{array}{l}0.87 \\
0.96 \\
1.00\end{array}$ \\
\hline IZ 980 & $\begin{array}{l}0.81 \\
0.99 \\
2.70\end{array}$ \\
\hline
\end{tabular}

QUADRO DA ANÁLISE DA VARIÂNCIA

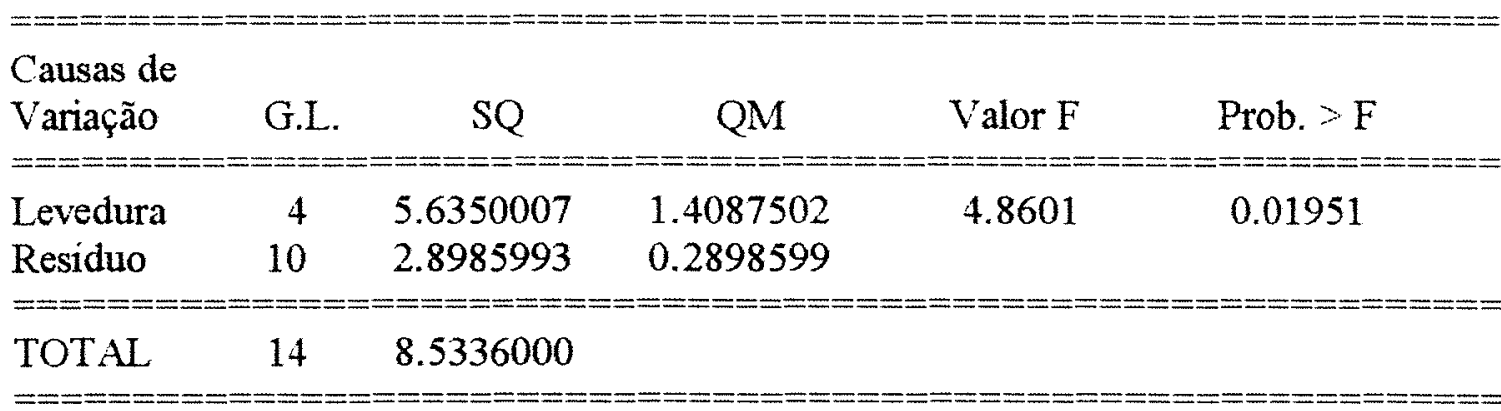

Média Geral $=1.290000$

Coeficiente de variação $=41.735 \%$ 
TABELA 3. Dados originais e análise de variância do teor de trealose (\%) do experimento $3 \mathrm{em}$ leveduras após fermentação em meio de mosto de melaço com $5 \%$ de ART, com baixa concentração de inóculo e sem reciclo de células.

\begin{tabular}{|c|c|}
\hline Leveduras & TREALOSE $(\%)$ \\
\hline \multirow{4}{*}{ IZ 1904} & 0.90 \\
\hline & 0.76 \\
\hline & 0.89 \\
\hline & 0.91 \\
\hline \multirow{4}{*}{ IZ 1352} & 1.46 \\
\hline & 1.53 \\
\hline & 0.80 \\
\hline & 1.13 \\
\hline \multirow{4}{*}{ IZ 1279} & 0.92 \\
\hline & 1.02 \\
\hline & 0.67 \\
\hline & 1.02 \\
\hline \multirow{4}{*}{ IZ 1831} & 4.04 \\
\hline & 4.39 \\
\hline & 5.67 \\
\hline & 5.94 \\
\hline \multirow{4}{*}{ IZ 1256} & 0.80 \\
\hline & 0.66 \\
\hline & 0.97 \\
\hline & 1.41 \\
\hline
\end{tabular}

\section{QUADRO DA ANÁLISE DA VARIÂNCLA}

\begin{tabular}{|c|c|c|c|c|c|}
\hline $\begin{array}{l}\text { Causas de } \\
\text { Variação }\end{array}$ & G.L. & SQ & QM & Valor F & Prob. $>\mathrm{F}$ \\
\hline $\begin{array}{l}\text { Levedura } \\
\text { Resíduo }\end{array}$ & $\begin{array}{r}4 \\
15\end{array}$ & $\begin{array}{r}53.3335937 \\
3.8792470\end{array}$ & $\begin{array}{r}13.3333984 \\
0.2586165\end{array}$ & 51.5566 & 0.00001 \\
\hline TOTAL & 19 & 57.2128407 & & & \\
\hline
\end{tabular}


TABELA 4. Dados originais e análise de variância de trealose $(\%)$ do experimento 4 obtidos após fermentaçăo em meio com $12 \%$ de ART, com baixa concentração de inóculo e sem reciclo de células.

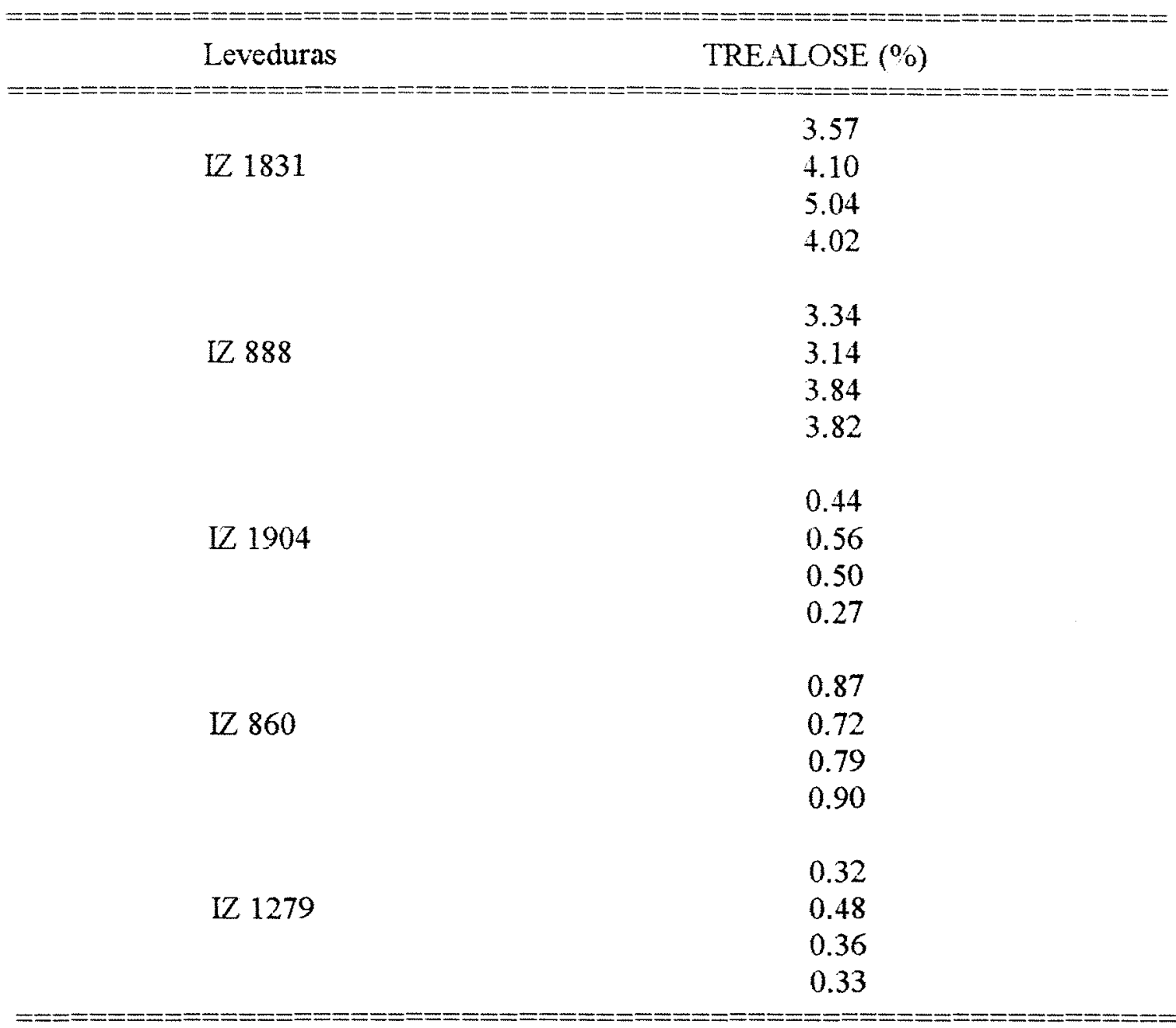

\section{QUADRO DA ANÁLISE DE VARIÂNCIA}

\begin{tabular}{|c|c|c|c|c|c|}
\hline $\begin{array}{l}\text { Causas de } \\
\text { Variação }\end{array}$ & G.L. & $\mathrm{SQ}$ & QM & Valor F & Prob $>F$ \\
\hline Levedura & 4 & 54.0105633 & 13.5026408 & \multirow[t]{2}{*}{126.9897} & 0.00001 \\
\hline Residuo & 15 & 1.5949300 & 0.1063287 & & \\
\hline TOTAL & 19 & 55.6054933 & & & \\
\hline
\end{tabular}

Média Geral $=1.870500$

Coeficiente de variação $=17.433 \%$ 
TABELA 5. Dados originais e análise de variância para produção de etanol (\%) por leveduras no experimento 1 , após fermentação meio de mosto melaço com $5 \%$ de ART, baixa concentração de inóculo e sem reciclo de células.

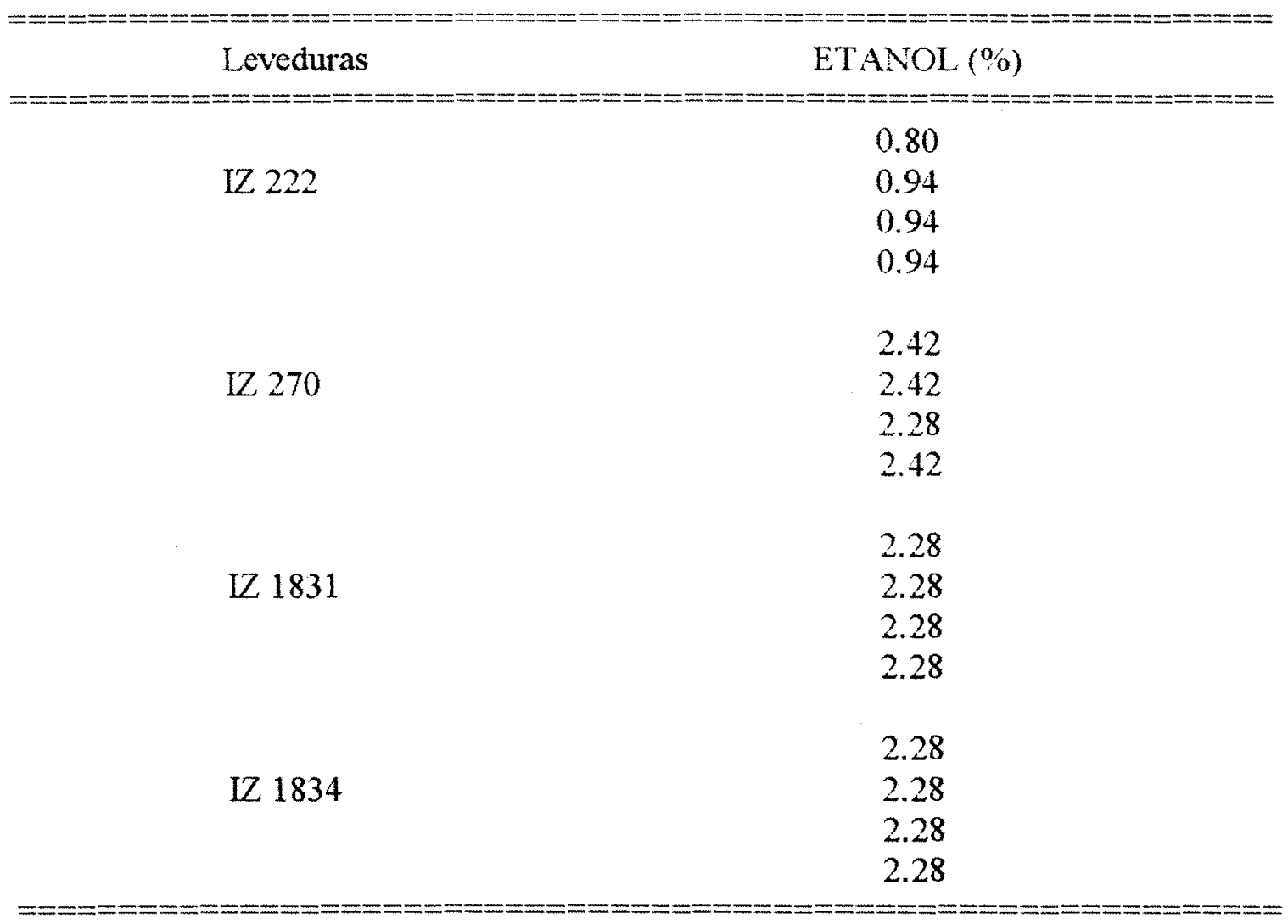

QUADRO DA ANÁLISE DE VARIÂNCIA

\begin{tabular}{|c|c|c|c|c|c|}
\hline $\begin{array}{l}\text { Causas de } \\
\text { Variação }\end{array}$ & G.L. & SQ & $\mathrm{QM}$ & Valor $\mathrm{F}$ & Prob $=F$ \\
\hline $\begin{array}{l}\text { Levedura } \\
\text { Residuo }\end{array}$ & $\begin{array}{r}3 \\
12\end{array}$ & $\begin{array}{l}6.2934738 \\
0.0343012\end{array}$ & $\begin{array}{l}2.0978246 \\
0.0028584\end{array}$ & 733.9081 & 0.00001 \\
\hline TOTAL & 15 & 6.3277750 & & & \\
\hline
\end{tabular}


TABELA 6. Dados originais para produção de etanol (\%) por leveduras no experimento 2 , após fermentação em meio de mosto de melaço com $5 \%$ de ART, baixa concentração de inóculo e sem reciclo de células.

\begin{tabular}{|c|c|}
\hline Leveduras & *ETANOL $(\%)$ \\
\hline IZ 888 & $\begin{array}{l}2.28 \\
2.28 \\
2.28\end{array}$ \\
\hline IZ 878 & $\begin{array}{l}2.28 \\
2.28 \\
2.16\end{array}$ \\
\hline IZ 879 & $\begin{array}{l}2.28 \\
2.28 \\
2.28\end{array}$ \\
\hline IZ 860 & $\begin{array}{l}2.28 \\
2.28 \\
2.28\end{array}$ \\
\hline IZ 980 & $\begin{array}{l}2.28 \\
2.28 \\
2.28\end{array}$ \\
\hline
\end{tabular}

* Não foram feitas análises estatísticas. 
TABELA 7. Dados originais para produção de etanol (\%) por leveduras no experimento 3 , após fermentação em meio de mosto de melaço com $5 \%$ de ART, baixa concentração de inóculo e sem reciclo de células.

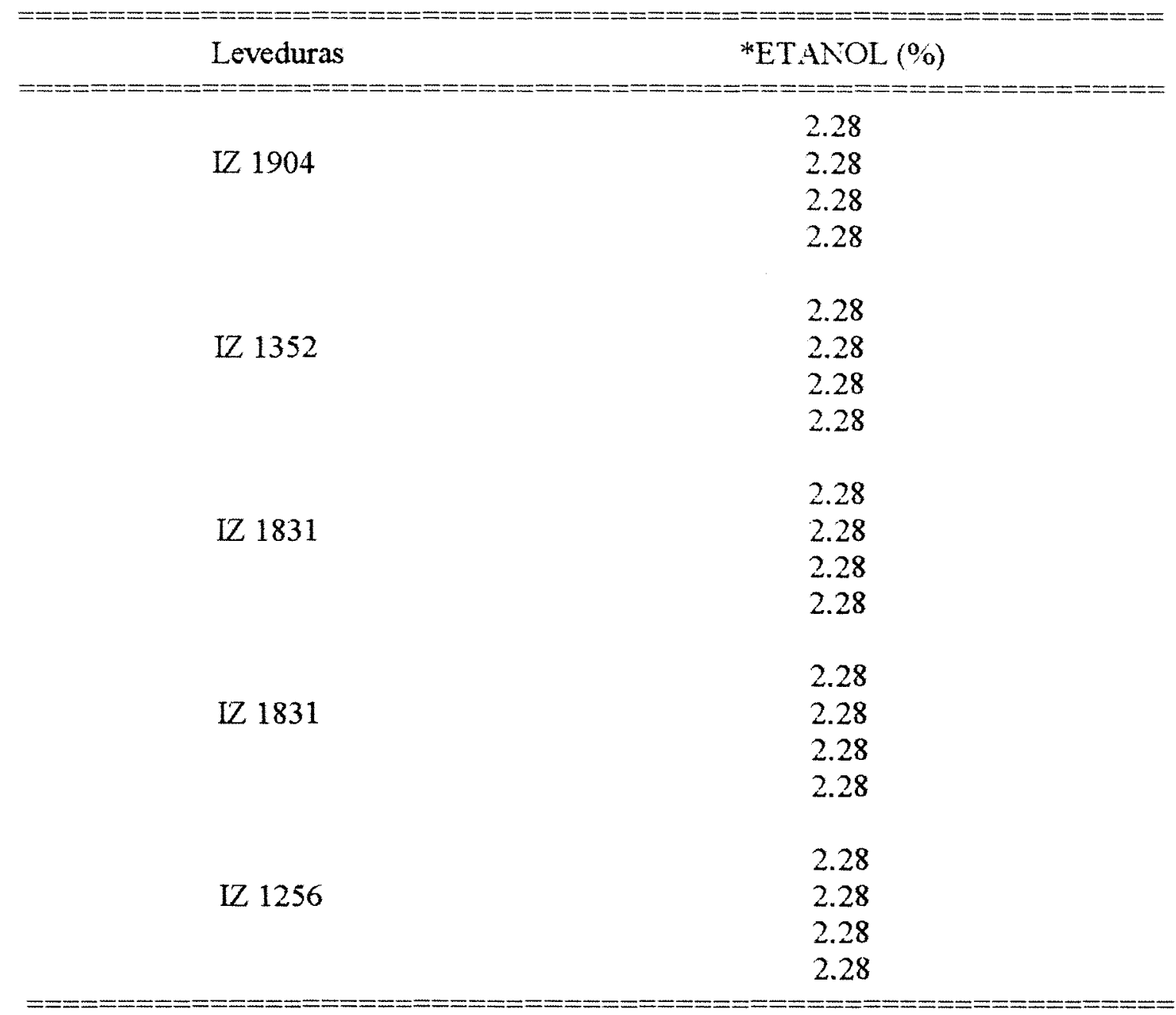

* Não foram feitas análises estatísticas. 
TABELA 8. Dados originais e análise de variância para produção de etanol $(\%)$ por leveduras no experimento 4, apos fermentação meio de mosto melaço com $12 \%$ de ART, baixa concentração de inóculo e sem reciclo de células.

\begin{tabular}{|c|c|}
\hline $\begin{array}{r}\text { Leveduras } \\
=-====-======\end{array}$ & ETANOL $(\%)$ \\
\hline LZ 1831 & $\begin{array}{l}5.58 \\
5.58 \\
5.58 \\
5.58\end{array}$ \\
\hline IZ 888 & $\begin{array}{l}5.58 \\
5.58 \\
5.58 \\
5.58\end{array}$ \\
\hline IZ 1904 & $\begin{array}{l}5.65 \\
5.65 \\
5.65 \\
5.58\end{array}$ \\
\hline IZ 860 & $\begin{array}{l}5.58 \\
5.58 \\
5.58 \\
5.44\end{array}$ \\
\hline IZ 1279 & $\begin{array}{l}5.44 \\
5.58 \\
5.58 \\
5.58\end{array}$ \\
\hline
\end{tabular}

QUADRO DA ANÁLISE DE VARIÂNCIA

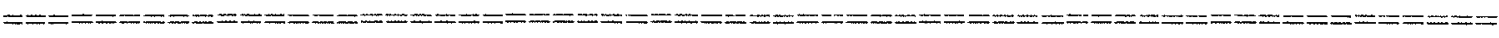

Causas de

Variação G.L. $\quad \mathrm{SQ} \quad \mathrm{QM} \quad$ Valor $F \quad$ Prob $>\mathrm{F}$

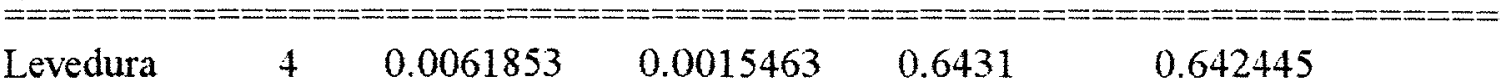

$\begin{array}{lrrrrr}\text { Levedura } & 4 & 0.0061853 & 0.0015463 & 0.6431 & 0.642445 \\ \text { Residuo } & 15 & 0.0360697 & 0.0024046 & & \end{array}$

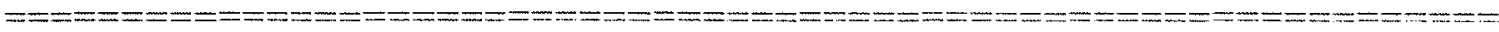

TOTAL $\quad 19 \quad 0.0422549$

Média Geral $=5.566500$

Coeficiente de variação $=0.881 \%$ 
TABELA 9. Dados originais de viabilidade celular $(\%)$ do experimento 1 para leveduras após fermentação em meio de mosto de melaço com $5 \%$ de ART, baixa concentração de inóculo. sem reciclo de células.

\begin{tabular}{|c|c|}
\hline Leveduras & "VLABILIDADE $(\%)$ \\
\hline IZ 222 & 96.61 \\
\hline IZ 270 & +4.87 \\
\hline IZ 1831 & 87.85 \\
\hline IZ 1834 & 70.56 \\
\hline
\end{tabular}

* Não foram feitas análises estatísticas. 
TABELA 10. Dados originais e análise de variância de viabilidade celular $(\%)$ do experimento 2 para leveduras após fermentação em meio de mosto de melaço com $5 \%$ de ART, com baixa concentração de inóculo, sem reciclo de células.

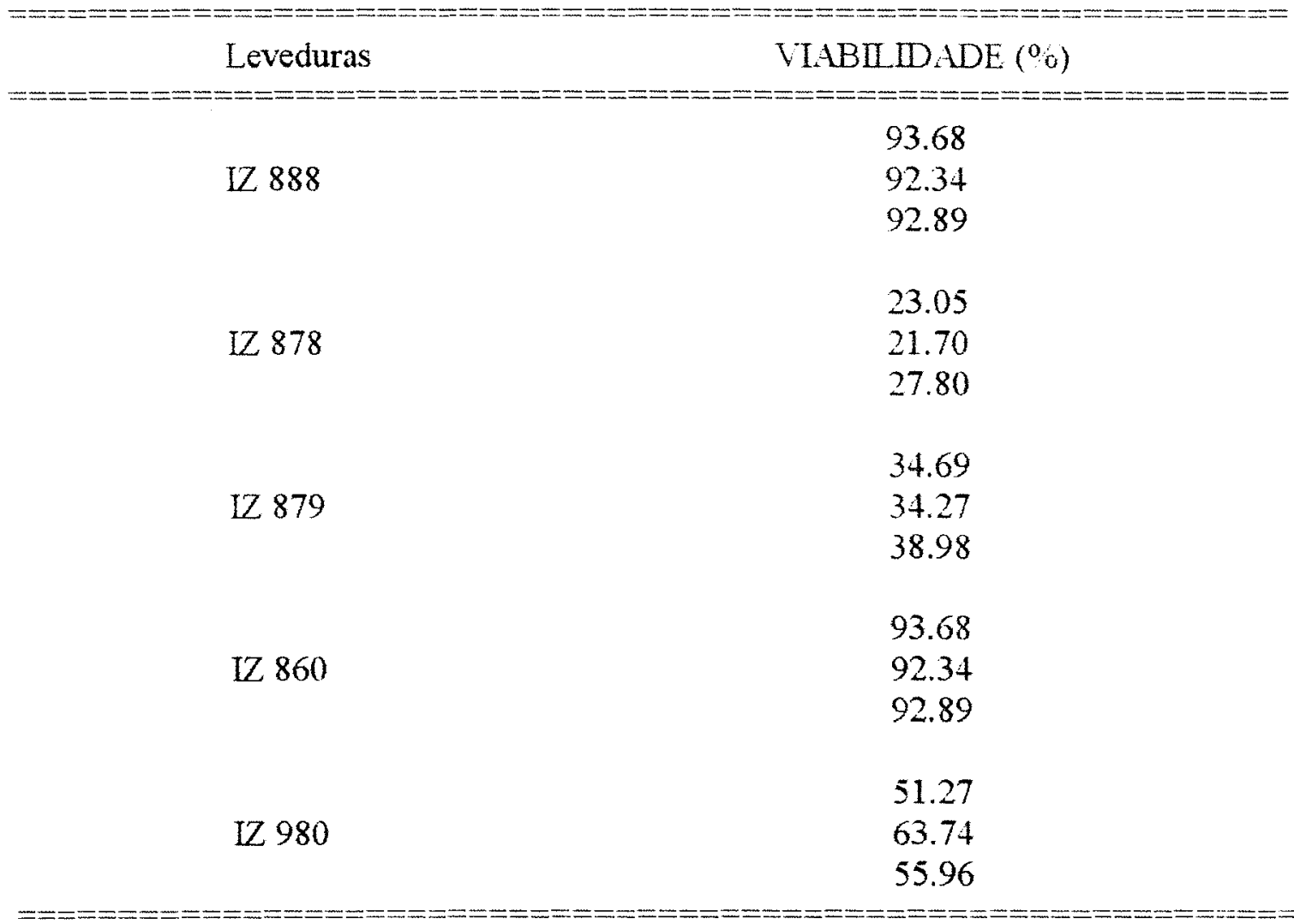

QUADRO DA ANÁLISE DE VARIÂNCIA

\begin{tabular}{|c|c|c|c|c|c|}
\hline $\begin{array}{l}\text { Causas de } \\
\text { Variação }\end{array}$ & G.L. & SQ & $\mathrm{QM}$ & Valor F & Prob $>F$ \\
\hline $\begin{array}{l}\text { Levedura } \\
\text { Residuo }\end{array}$ & $\begin{array}{r}4 \\
10\end{array}$ & $\begin{array}{r}5305.3032756 \\
42.9733222\end{array}$ & $\begin{array}{r}1326.3258189 \\
42973322\end{array}$ & 308.6393 & 0.00001 \\
\hline$=====$ & & $==========$ & $==========$ & $==== \pm===$ & $=====-===$ \\
\hline TOTAL & 14 & 5348.2765978 & & & \\
\hline
\end{tabular}


TABELA 11. Dados originais e anáiise de variância de viabilidade celular $(\%)$ do experimento 3 para leveduras após fermentação em meio de mosto de melaço com $5 \%$ de ART, com baxa concentração de inóculo, sem reciclo de células.

\begin{tabular}{|c|c|}
\hline Leveduras & VIABILIDADE $(\%)$ \\
\hline IZ 1904 & $\begin{array}{l}91.88 \\
89.43 \\
87.88 \\
92.20\end{array}$ \\
\hline IZ 1352 & $\begin{array}{l}83.86 \\
80.08 \\
84.33 \\
81.26\end{array}$ \\
\hline IZ 1279 & $\begin{array}{l}84.33 \\
87.13 \\
88.00 \\
87.36\end{array}$ \\
\hline IZ 1831 & $\begin{array}{l}96.85 \\
95.60 \\
97.27 \\
97.03\end{array}$ \\
\hline IZ 1256 & $\begin{array}{l}90.40 \\
83.67 \\
84.74 \\
82.12\end{array}$ \\
\hline
\end{tabular}

QUADRO DA ANÁLISE DE VARIÂNCIA

\begin{tabular}{|c|c|c|c|c|c|}
\hline $\begin{array}{l}\text { Causas de } \\
\text { Variação }\end{array}$ & G.L. & SQ & QM & Valor $F$ & Prob $>F$ \\
\hline Levedura & 4 & 497.93785669 & 124.48446442 & 33.0810 & 0.00001 \\
\hline Resíduo & 15 & 56.4452967 & 3.7630198 & & \\
\hline TOTAL & 19 & 554.3831537 & & & \\
\hline
\end{tabular}

Média Geral $=70.580956$

Coeficiente de variação $=2.748 \%$ 
TABELA 12. Dados originais e análise de variancia de viabilidade celular $(\%)$ do experimento 4 para leveduras após fermentação em meio de mosto de melaço com $12 \%$ de ART, com baixa concentração de inóculo, sem reciclo de células.

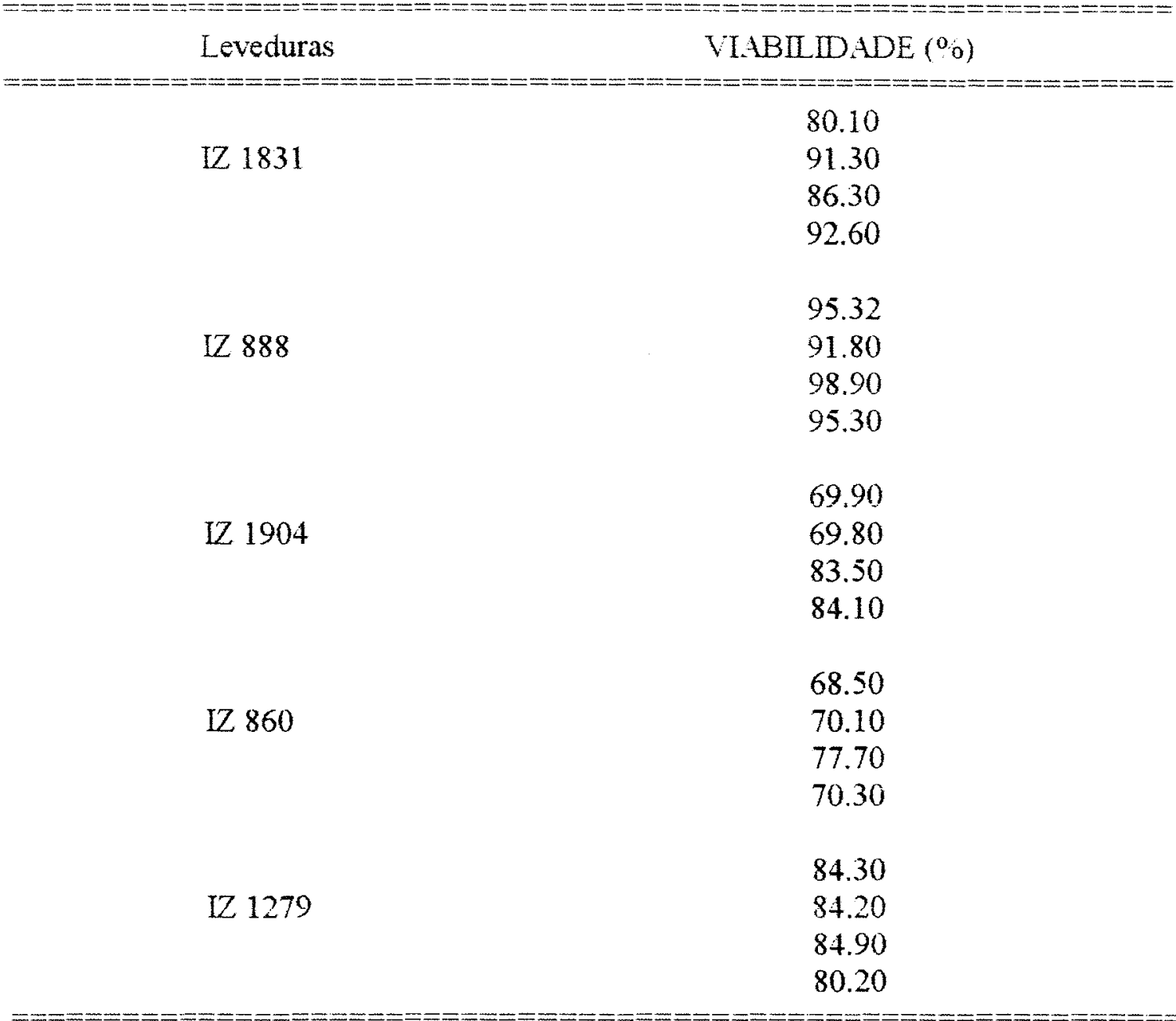

QUADRO DA ANÁLISE DE VARIÂNCIA

\begin{tabular}{|c|c|c|c|c|c|}
\hline $\begin{array}{l}\text { Causas de } \\
\text { Variação }\end{array}$ & G.L. & $\mathrm{SQ}$ & QM & Valor $F$ & Prob $>F$ \\
\hline Levedura & 4 & 976.6607513 & 244.1651878 & \multirow[t]{2}{*}{14.6753} & \multirow[t]{2}{*}{0.00013} \\
\hline Residuo & 15 & 249.5673489 & 16.6378233 & & \\
\hline $\begin{array}{l}======= \\
\text { TOTAL }\end{array}$ & $\begin{array}{l}=== \\
19\end{array}$ & $\begin{array}{l}======== \\
1226.2281001\end{array}$ & 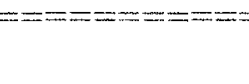 & $=== \pm=$ & $=--=-2=$ \\
\hline
\end{tabular}

Média Geral $=66.627350$

Coeficiente de variação $=6.122 \%$ 
TABELA 13. Dados originais de Brotamento celular $(\%)$ do experimento 1 para leveduras após fermentação em meio de mosto de melaço com $5 \%$ ae ART, com baixa concentração de inóculo, sem reciclo de células.

\begin{tabular}{|c|c|}
\hline Leveduras & *BROT AMENTO $(\%)$ \\
\hline IZ 222 & 32.46 \\
\hline 12270 & 2.86 \\
\hline IZ 1831 & 17.02 \\
\hline IZ 1834 & 13.66 \\
\hline
\end{tabular}

* Não foram feitas análises estatísticas. 
TABELA 14. Dados originais e analise de variancia de Brotamento ceiular $(0)$ do experimento 2 para leveduras apos fermentação em meio de mosto de melaço com 5\% de ART. com baixa concentração de inóculo, sem reciclo de células.

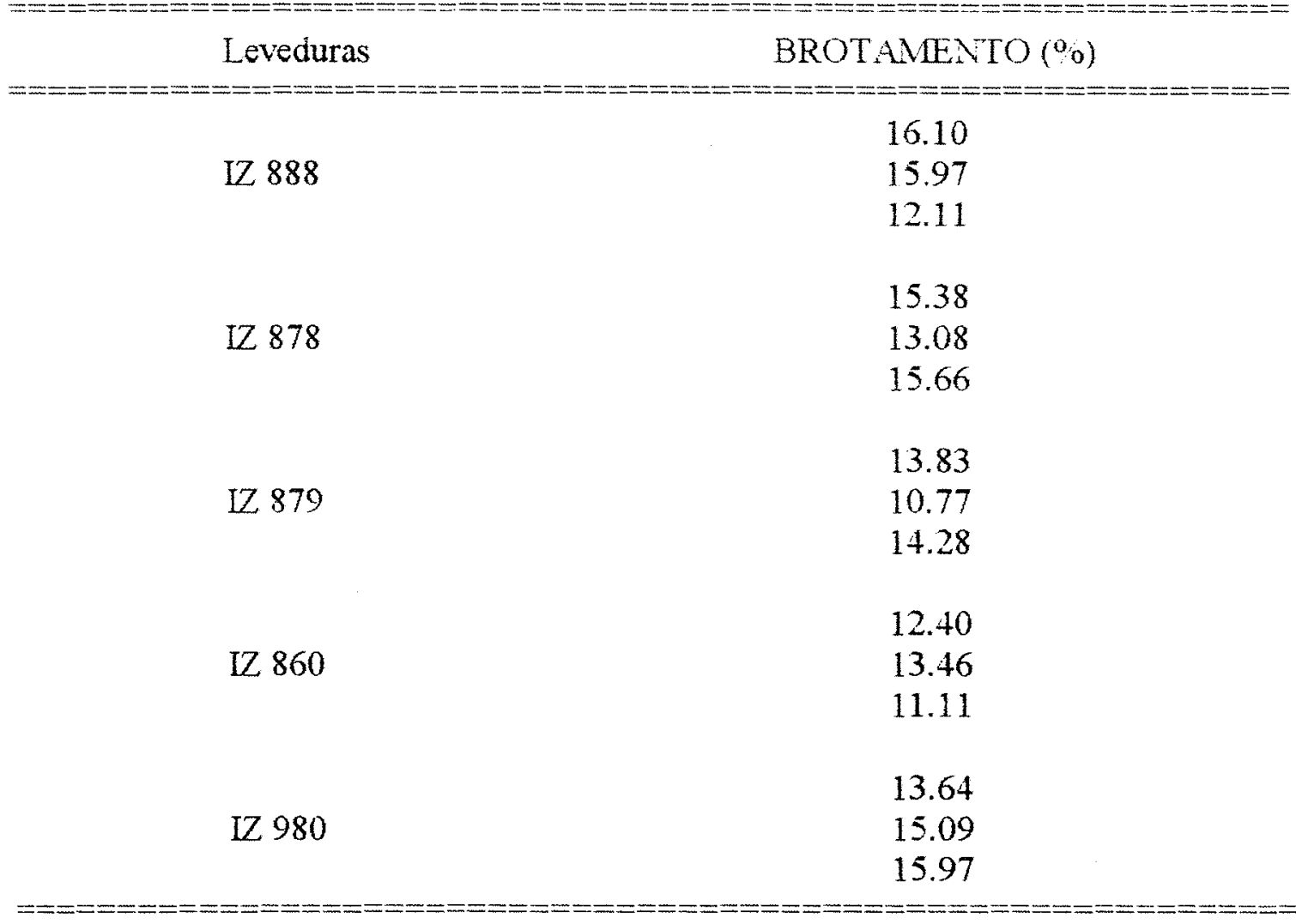

QUADRO DA ANÁLISE DE VARIÂNCLA

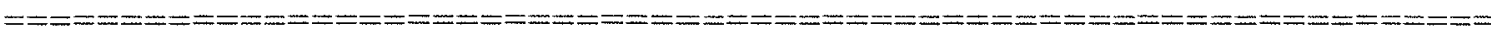

Causas de

\begin{tabular}{|c|c|c|c|c|c|}
\hline $\begin{array}{l}\text { Variação } \\
======\end{array}$ & G.L. & $\mathrm{SQ}$ & QM & Valor F & $\begin{array}{l}\text { Prob }>F \\
\end{array}$ \\
\hline Levedura & 4 & 6.8510266 & 1.7127567 & 0.2419 & 0.90700 \\
\hline Residuo & 10 & 70.7972325 & 7.0797232 & & \\
\hline TOTAL & 14 & 77.6482591 & & & \\
\hline
\end{tabular}

Média Geral $=22.367868$

Coeficiente de variação $=11.896 \%$ 
TABELA 15. Dados originais e analise de variancia de Brotamento celular $(\%)$ cio experimento 3 para leveduras após fermentação em meio de mosto de melaço com $5 \%$ de ART, com baixa concentração de inóculo. sem reciclo de células.

\begin{tabular}{|c|c|}
\hline Leveduras & BROTAMENTO $(\%)$ \\
\hline IZ 1904 & $\begin{array}{l}22.86 \\
22.86 \\
22.13 \\
23.51\end{array}$ \\
\hline IZ 1352 & $\begin{array}{l}16.60 \\
15.96 \\
15.48 \\
13.51\end{array}$ \\
\hline IZ 1279 & $\begin{array}{l}12.18 \\
18.15 \\
25.56 \\
15.19\end{array}$ \\
\hline IZ 1831 & $\begin{array}{l}7.50 \\
5.20 \\
5.18 \\
3.80\end{array}$ \\
\hline IZ 1256 & $\begin{array}{r}10.58 \\
9.02 \\
7.07 \\
9.75\end{array}$ \\
\hline
\end{tabular}

QUADRO DA ANÁLISE DE VARIÂNCIA

\begin{tabular}{|c|c|c|c|c|c|}
\hline $\begin{array}{l}\text { Causas de } \\
\text { Variação }\end{array}$ & G.L. & SQ & QM & Valor $F$ & Prob $>F$ \\
\hline Levedura & 4 & 568.7042028 & 142.1760507 & 27.8080 & 0.00001 \\
\hline Resíduo & 15 & 76.6916276 & 5.1127752 & & \\
\hline TOTAL & 19 & 645.3958304 & & & \\
\hline
\end{tabular}

Média Geral $=21.415827$

Coeficiente de variação $=10.558 \%$ 
TABELA 16. Dados originais e análise de variància de Brotamento celular $(\%)$ do experimento 4 para leveduras após fermentação em meio de mosto de melaço com $12 \%$ de ART, com baixa concentração de inóculo, sem reciclo de células.

\begin{tabular}{|c|c|}
\hline Leveduras & BROTAMENTO $\left({ }^{\circ}\right)$ \\
\hline \multirow{4}{*}{ IZ 1831} & 5.70 \\
\hline & 9.50 \\
\hline & 3.10 \\
\hline & 2.30 \\
\hline \multirow{4}{*}{ IZ 888} & 8.80 \\
\hline & 12.70 \\
\hline & 8.50 \\
\hline & 14.40 \\
\hline \multirow{4}{*}{ IZ 1904} & 14.10 \\
\hline & 12.50 \\
\hline & 12.20 \\
\hline & 12.20 \\
\hline \multirow{4}{*}{ IZ 860} & 12.10 \\
\hline & 15.50 \\
\hline & 14.40 \\
\hline & 8.50 \\
\hline \multirow{4}{*}{ IZ 1279} & 10.70 \\
\hline & 3.10 \\
\hline & 3.10 \\
\hline & 7.50 \\
\hline
\end{tabular}

QUADRO DA ANÁLISE DE VARIÂNCIA

\begin{tabular}{|c|c|c|c|c|c|}
\hline $\begin{array}{l}\text { Causas de } \\
\text { Variação }\end{array}$ & G.L. & SQ & QM & Valor $F$ & Prob $>F$ \\
\hline Levedura & 4 & $\begin{array}{l}249.1697757 \\
162490313\end{array}$ & $\begin{array}{l}62.29244339 \\
104166021\end{array}$ & 5.9801 & 0.00468 \\
\hline$======$ & & & & & \\
\hline TOTAL & 19 & 405.4188070 & & & \\
\hline
\end{tabular}


TABEL 1 17. Dados originais e análise de varianncia para o teor de matéria seca (g $\mathrm{m} . \mathrm{s} / 100 \mathrm{ml}$ ) em leveduras no experimento 1 após fermentação em meio de mosto melaço com 5\% de ART. baixa concentração de inóculo e sem reciclo de células.

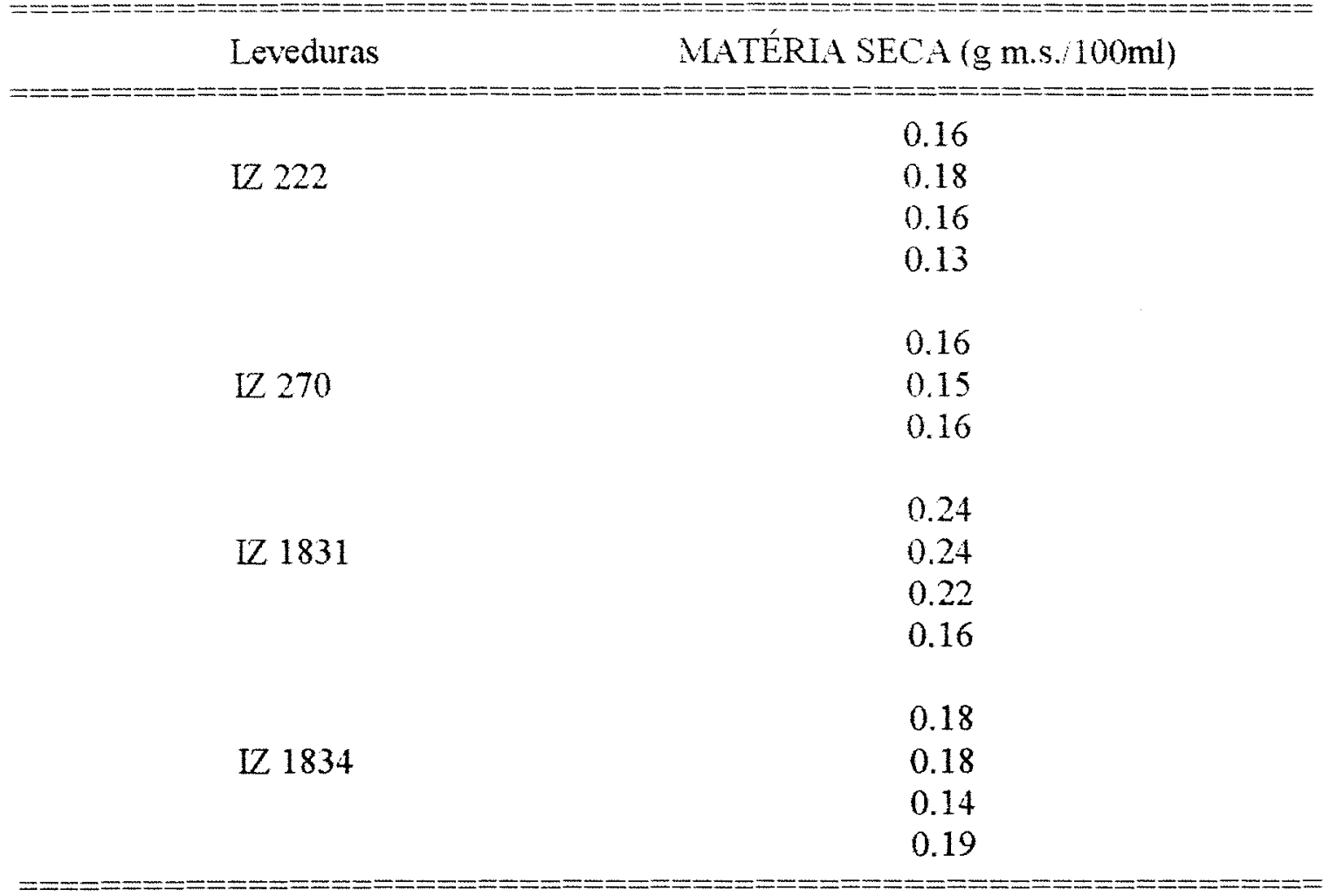

QUADRO DA ANÁLISE DE VARIÂNCIA

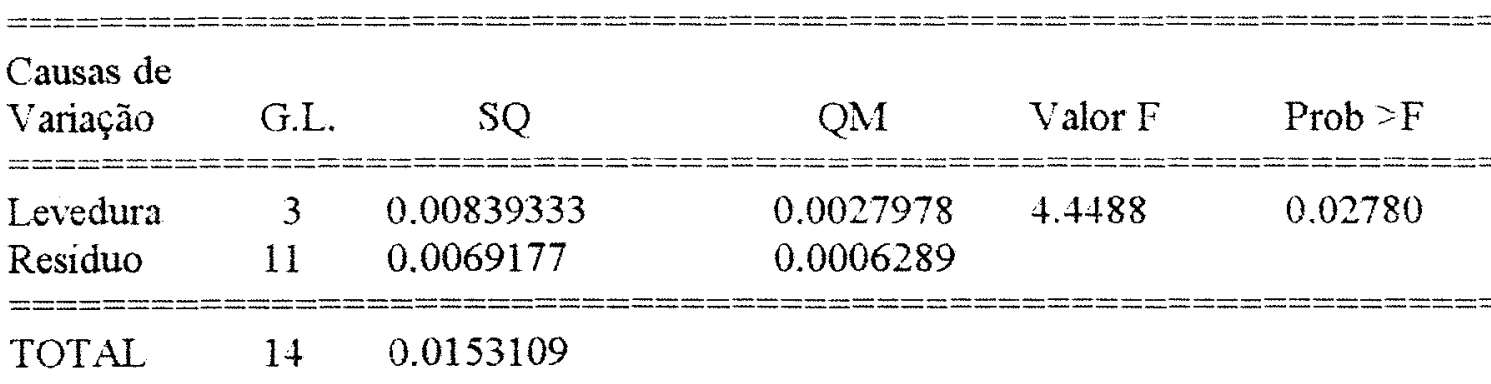

$=============$
Média Geral $=0.177067$

Coeficiente de variação $=14.163 \%$ 
TABELA 18. Dados originais e análise de variância do teor de matéria seca ( $\mathrm{g}$ m.s. 100 ml) do experimento 2 em leveduras após fermentação em meio de mosto de melaço com $5 \%$ de ART, com baixa concentração de inóculo, sem reciclo de células.

\begin{tabular}{|c|c|}
\hline Leveduras & MATÉRLA SECA (g m.s. $100 \mathrm{ml}$ ) \\
\hline IZ 888 & $\begin{array}{l}0.18 \\
0.20 \\
0.20\end{array}$ \\
\hline IZ 878 & $\begin{array}{l}0.16 \\
0.19 \\
0.20\end{array}$ \\
\hline IZ 879 & $\begin{array}{l}0.20 \\
0.18 \\
0.18\end{array}$ \\
\hline IZ 860 & $\begin{array}{l}0.19 \\
0.19 \\
0.19\end{array}$ \\
\hline IZ 980 & $\begin{array}{l}0.20 \\
0.20 \\
0.40\end{array}$ \\
\hline
\end{tabular}

QUADRO DA ANÁLISE DE VARIÂNCIA

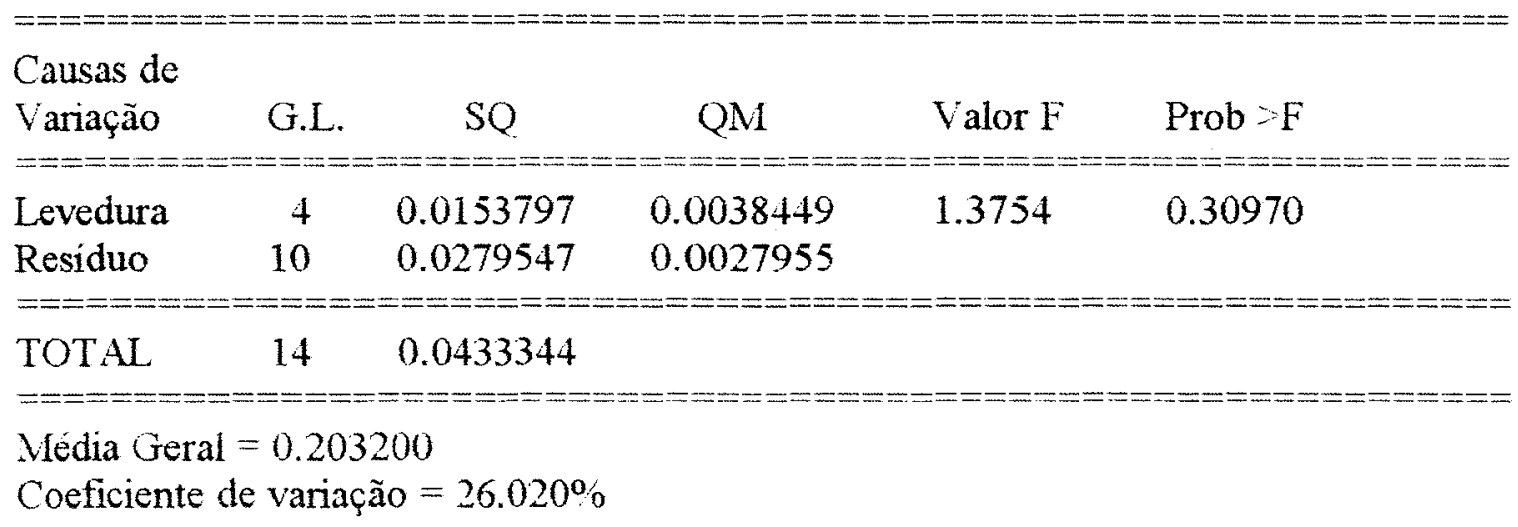


TABELA 19. Dados originais e anáiise de variància do teor de matéria seca (g m.s. 100 $\mathrm{ml})$ do experimento $3 \mathrm{em}$ leveduras após fermentação em meio de mosto de melaço com $5^{\circ}$ de ART, com baixa concentração de inóculo, sem reciclo de células.

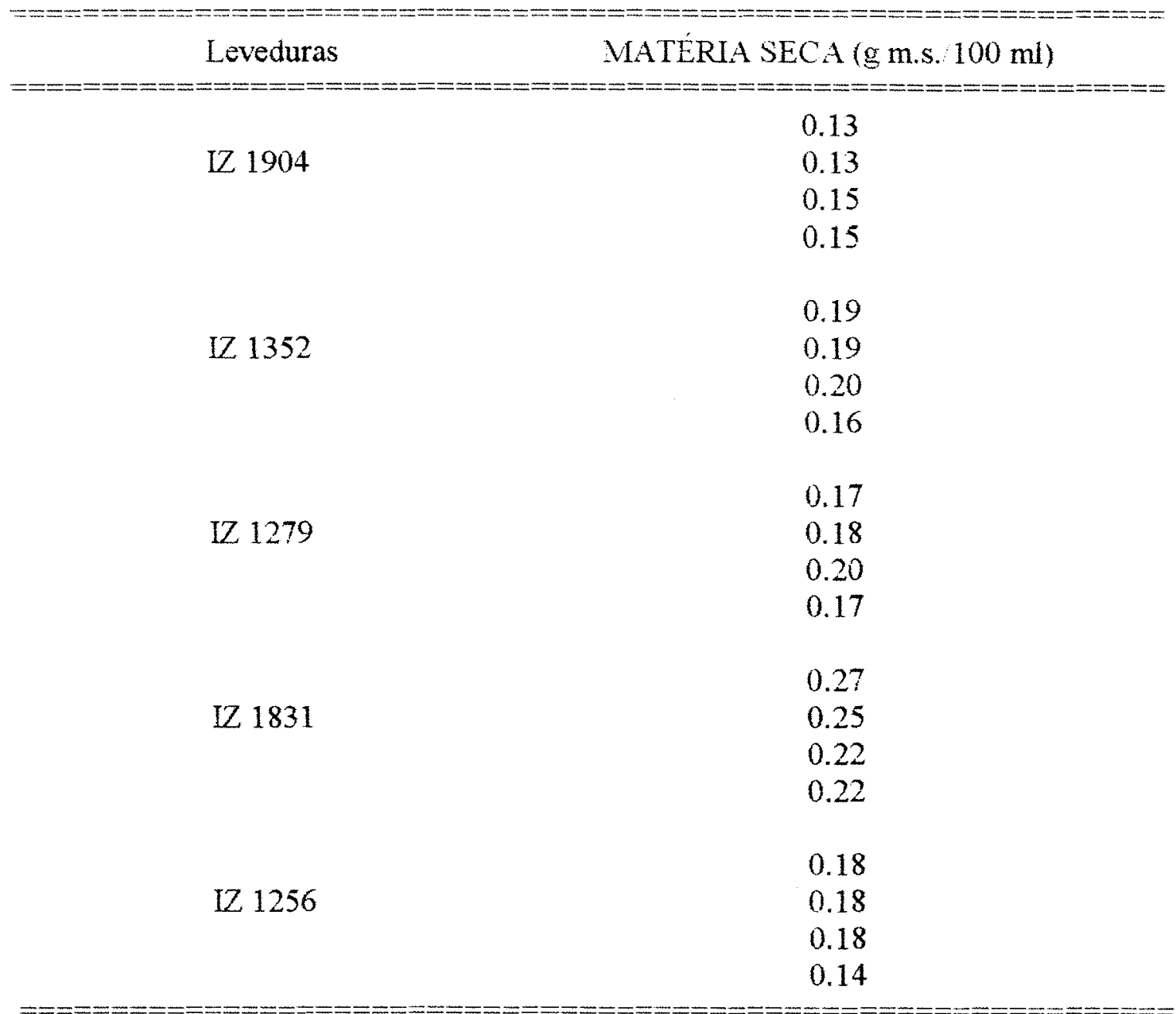

QUADRO DA ANÁLISE DE VARIÂNCIA

\begin{tabular}{|c|c|c|c|c|c|}
\hline $\begin{array}{l}\text { Causas de } \\
\text { Variação }\end{array}$ & G.L. & SQ & QM & Valor $F$ & Prob $>F$ \\
\hline $\begin{array}{l}\text { Levedura } \\
\text { Residuo }\end{array}$ & $\begin{array}{r}4 \\
15\end{array}$ & $\begin{array}{l}0.0210672 \\
0.0040360\end{array}$ & $\begin{array}{l}0.0052668 \\
0.0002691\end{array}$ & 19.5743 & 0.00005 \\
\hline TOTAL & 19 & 0.0251032 & & & \\
\hline
\end{tabular}

Média Geral $=0.182200$

Coeficiente de variação $=9.003 \%$ 
TABELA 20. Dados originais e análise de variância do teor de matéria seca (g m.s. 100 ml) do experimento 4 em leveduras apos fermentação em meio de mosto de melaço com $12 \%$ de ART, com baixa concentração de inóculo, sem reciclo de células.

\begin{tabular}{|c|c|}
\hline Leveduras & MATÉRIA SECA (g m.s. $100 \mathrm{ml})$ \\
\hline IZ 1831 & $\begin{array}{l}0.41 \\
0.39 \\
0.37 \\
0.48\end{array}$ \\
\hline 12888 & $\begin{array}{l}0.37 \\
0.36 \\
0.38 \\
0.43\end{array}$ \\
\hline IZ 1904 & $\begin{array}{l}0.46 \\
0.26 \\
0.24 \\
0.27\end{array}$ \\
\hline IZ 860 & $\begin{array}{l}0.29 \\
0.32 \\
0.32 \\
0.31\end{array}$ \\
\hline IZ 1279 & $\begin{array}{l}0.36 \\
0.33 \\
0.37 \\
0.35\end{array}$ \\
\hline
\end{tabular}

QUADRO DA ANÁLISE DE VARIÂNCIA

\begin{tabular}{|c|c|c|c|c|c|}
\hline $\begin{array}{l}\text { Causas de } \\
\text { Variação }\end{array}$ & G.L. & $\mathrm{SQ}$ & QM & Valor $\mathrm{F}$ & Prob $>F$ \\
\hline Levedura & 4 & 0.0332301 & 0.0083075 & \multirow[t]{2}{*}{2.9654} & \multirow[t]{2}{*}{0.05412} \\
\hline Residuo & 15 & 0.0420219 & 0.0028015 & & \\
\hline TOTAL & 19 & 0.0752520 & & & \\
\hline
\end{tabular}

Média Geral $=0.353000$

Coeficiente de variação $=14.9994 \%$ 
TABELA 21. Dados originais e análise de variância de $A R(g / 100 \mathrm{ml})$ para as leveduras IZ 888 e M-300-A após fermentação em meio de mosto de melaço com $12 \%$ de ART, alta concentração de inóculo e 5 reciclos de células.

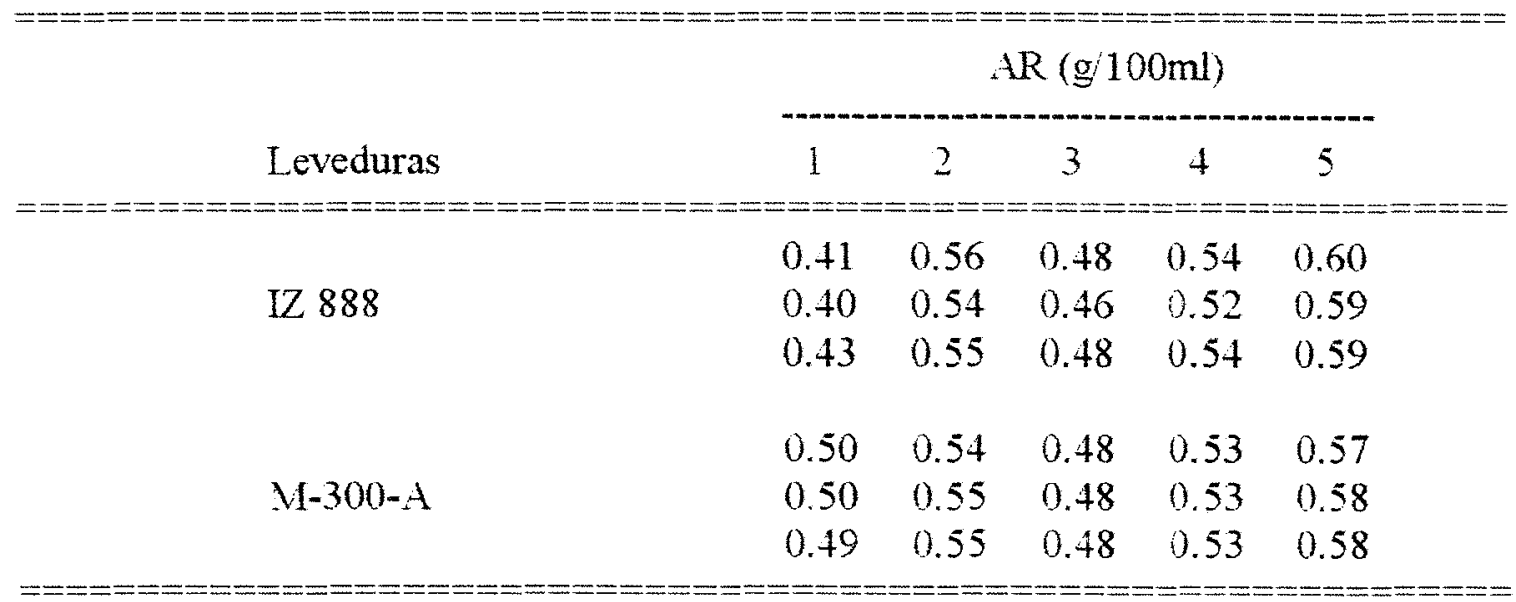

QUADRO DA ANÁLISE DE VARIANNCIA

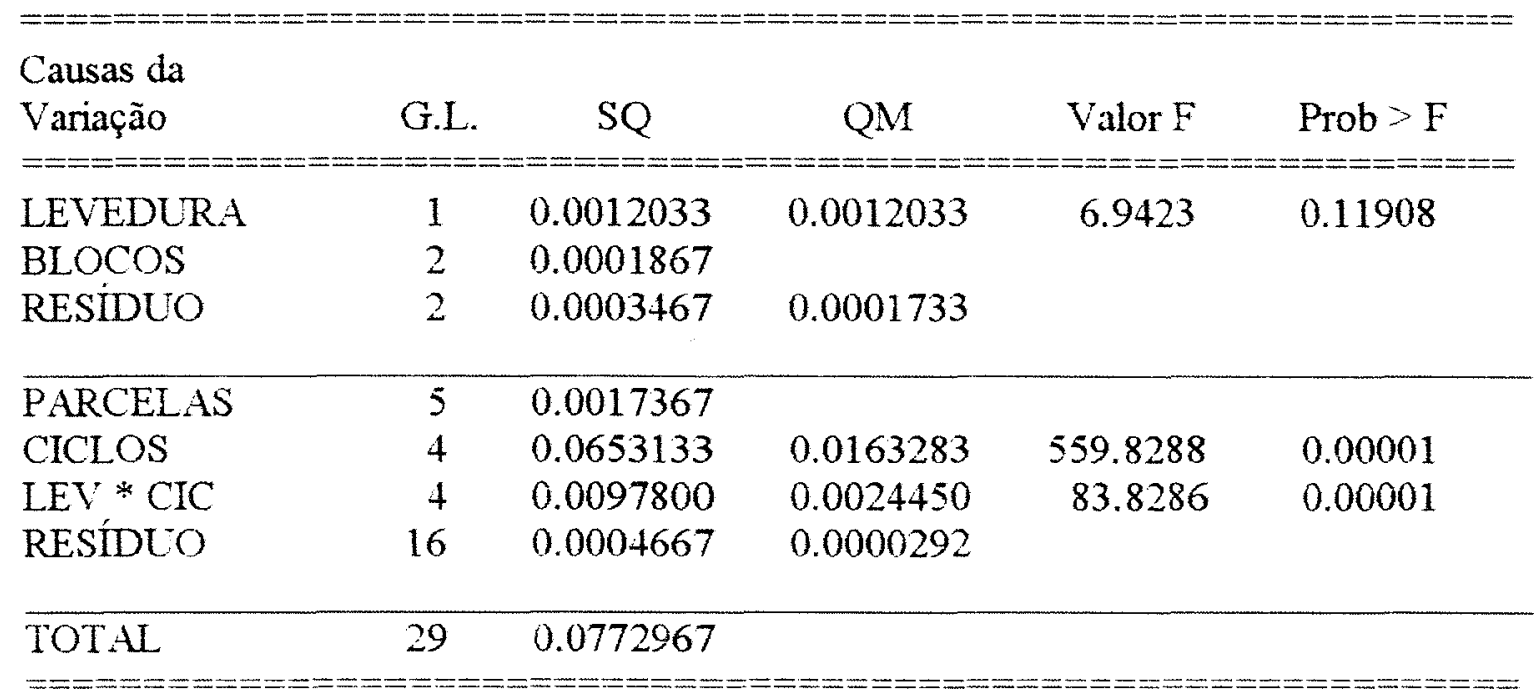

Média Geral $=0.520333$

Coeficiente de Variação $(A)=1.132 \%$

Coeficiente de Variação $(B)=1.038 \%$ 
TABELA 22. Dados originais e análise de variancia de Glicerol $(\mathrm{g} / 100 \mathrm{ml})$ para as leveduras $\mathrm{ZZ} 888$ e M-300-A após fermentação em meio de mosto de melaço com $12 \%$ de ART, alta concentração de inóculo e 5 reciclos de células.

\begin{tabular}{|c|c|c|c|c|c|}
\hline \multirow[b]{2}{*}{ Leveduras } & \multicolumn{5}{|c|}{ GLICEROL $(\mathrm{g} / 100 \mathrm{ml})$} \\
\hline & 1 & 2 & 3 & 4 & 5 \\
\hline \multirow{3}{*}{ IZ 888} & 0.60 & 0.65 & 0.67 & 0.66 & 0.68 \\
\hline & 0.61 & 0.65 & 0.64 & 0.67 & 0.66 \\
\hline & 0.59 & 0.64 & 0.63 & 0.65 & 0.64 \\
\hline \multirow{3}{*}{$M-300-A$} & 0.52 & 0.52 & 0.53 & 0.57 & 0.53 \\
\hline & 0.51 & 0.52 & 0.53 & 0.55 & 0.53 \\
\hline & 0.51 & 0.52 & 0.52 & 0.55 & 0.53 \\
\hline
\end{tabular}

QUADRO DA ANÁLISE DA VARIÂNCLA

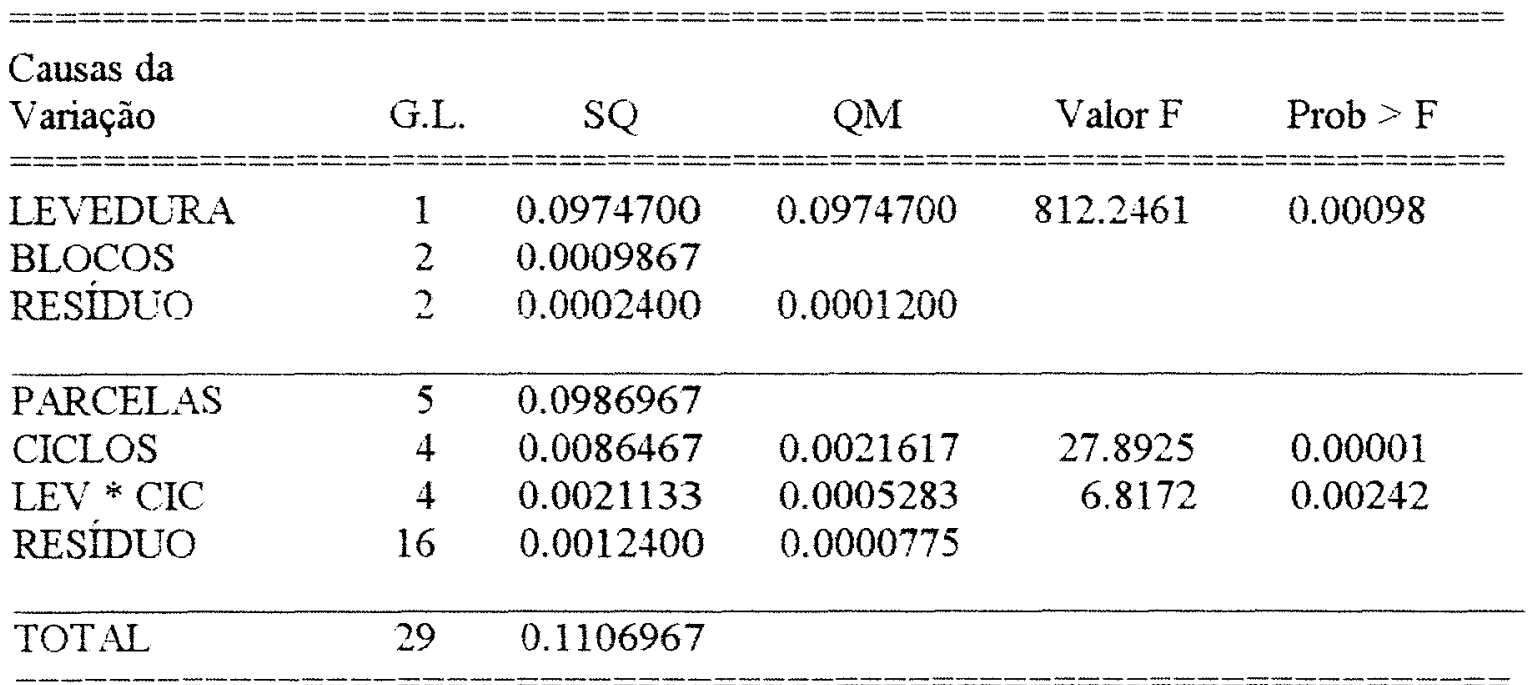

Média Geral $=0.586333$

Coeficiente de Variação $(A)=0.836 \%$

Coeficiente de Variação $(B)=1.501 \%$ 
TABELA 23. Dados originais e análise de variância da produção de etanol $(\%)$ pelas leveduras IZ 888 e M-300-A após fermentação em meio de mosto de relaçã com $12 \%$ de ART, alta concentração de inóculo e 5 reciclos de células.

\begin{tabular}{|c|c|c|c|c|c|}
\hline \multirow{2}{*}{ Leveduras } & \multicolumn{5}{|c|}{ ETANOL $(\%)$} \\
\hline & 1 & 2 & 3 & 4 & 5 \\
\hline \multicolumn{6}{|c|}{ 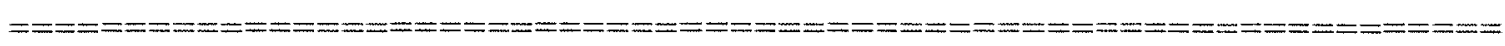 } \\
\hline \multirow{3}{*}{ IZ 888} & 5.72 & 6.28 & 6.49 & 6.49 & 6.37 \\
\hline & 5.72 & 6.28 & 6.49 & 6.49 & 6.49 \\
\hline & 5.86 & 6.28 & 6.42 & 6.56 & 6.49 \\
\hline \multirow{3}{*}{$\mathrm{M}-300-\mathrm{A}$} & 5.86 & 6.49 & 6.78 & 6.78 & 6.70 \\
\hline & 5.95 & 6.42 & 6.78 & 6.70 & 6.78 \\
\hline & 6.00 & 6.56 & 6.78 & 6.86 & 6.78 \\
\hline
\end{tabular}

QUADRO DA ANÁLISE DE VARIÂNCLA

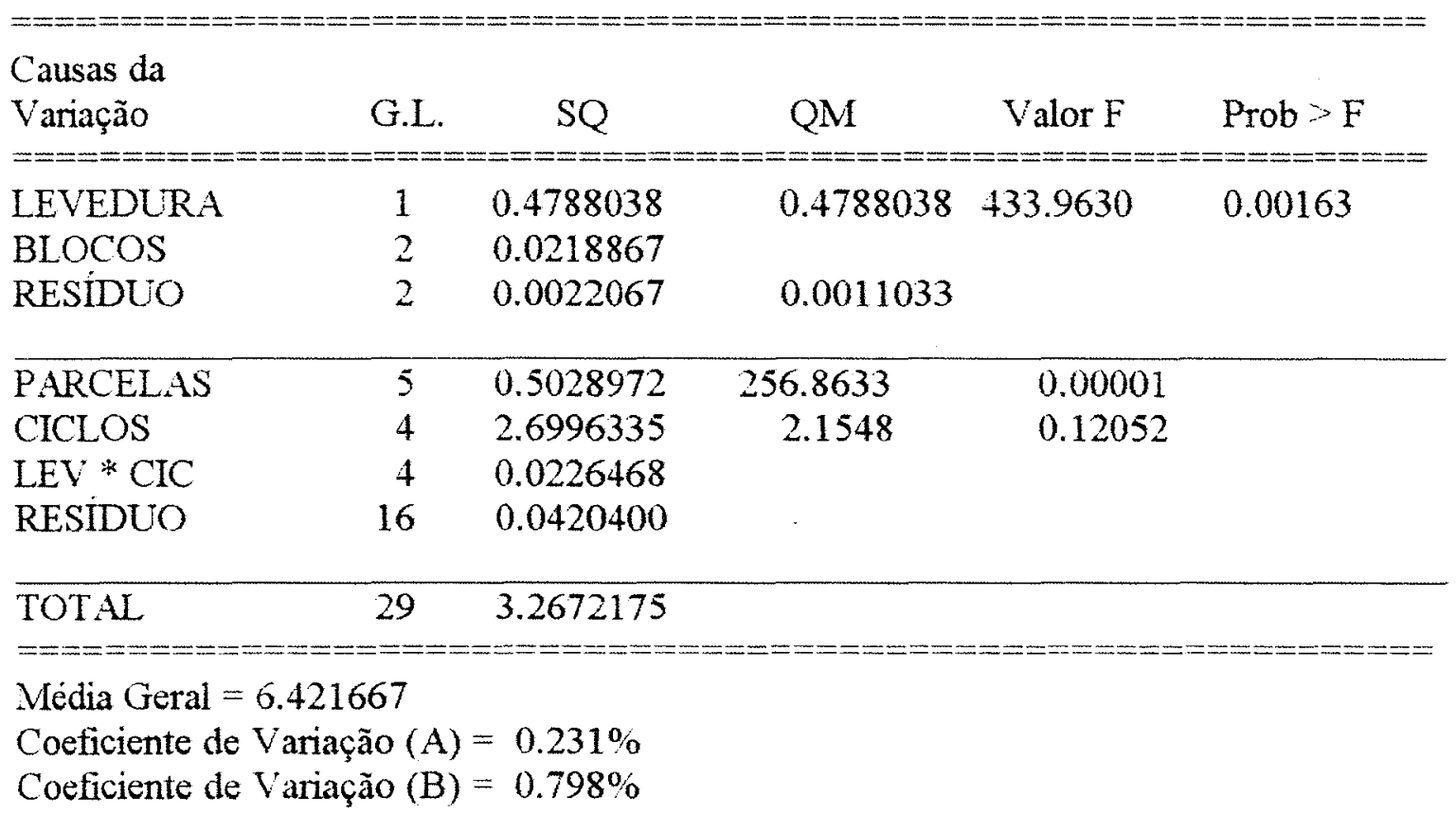


TABELA 24. Dados oniginais e análise de variancia da Viabilidade celular $(\%)$ pelas leveduras IZ 888 e M-300-A. após fermentação em meio de mosto de melaço com $12 \%$ de ART, alta concentração de inóculo e 5 reciclos de células.

\begin{tabular}{|c|c|c|c|c|c|}
\hline \multirow[b]{2}{*}{ Leveduras } & \multicolumn{5}{|c|}{ VIABILDADE $(\%)$} \\
\hline & 1 & 2 & 3 & 4 & 5 \\
\hline \multirow{3}{*}{ IZ 888} & 89.30 & 82.40 & 72.30 & 71.90 & 58.70 \\
\hline & 89.30 & 84.40 & 74.90 & 65.80 & 64.40 \\
\hline & 86.40 & 78.10 & 69.80 & 67.60 & 54.00 \\
\hline \multirow{3}{*}{$\mathrm{M}-300-\mathrm{A}$} & 97.70 & 90.80 & 83.60 & 77.30 & 64.90 \\
\hline & 93.50 & 93.00 & 80.60 & 77.30 & 69.30 \\
\hline & 94.30 & 93.30 & 81.60 & 79.20 & 61.40 \\
\hline
\end{tabular}

QUADKO DA ANÁLISE DE VARIÂNCIA

\begin{tabular}{|c|c|c|c|c|c|}
\hline $\begin{array}{l}\text { Causas da } \\
\text { Variaçãao }\end{array}$ & G.L. & SQ & $\mathrm{QM}$ & Valor $F$ & Prob $>F$ \\
\hline LEVEDURA & 1 & 330.8107346 & 330.8107346 & 66.9186 & 0.01140 \\
\hline BLOCOS & 2 & 19.4822346 & & & \\
\hline RESIDUO & 2 & 9.8869654 & 4.9434827 & & \\
\hline PARCELAS & 5 & 360.1799346 & & & \\
\hline CICLOS & 4 & 1774.1188034 & 443.5297008 & 122.2755 & 0.00001 \\
\hline $\mathrm{LEV} * \mathrm{CIC}$ & 4 & 25.7418873 & 6.4354718 & 1.7742 & 0.18290 \\
\hline RESIDUOO & 16 & 58.0367927 & 3.6272995 & & \\
\hline TOTAL & 29 & 2218.0774180 & & & \\
\hline
\end{tabular}

Média Geral $=63.135387$

Coeficiente de Variação $(A)=1.575 \%$

Coeficiente de Variação $(B)=3.017 \%$ 
TABELA 25. Dados originais e análise de variància de Brotamento celular (\%) pelas leveduras IZ 888 e M-300-A, após fermentação em meio de mosto de melaço com $12 \%$ de ART, alta concentração de inóculo e 5 reciclos de células.

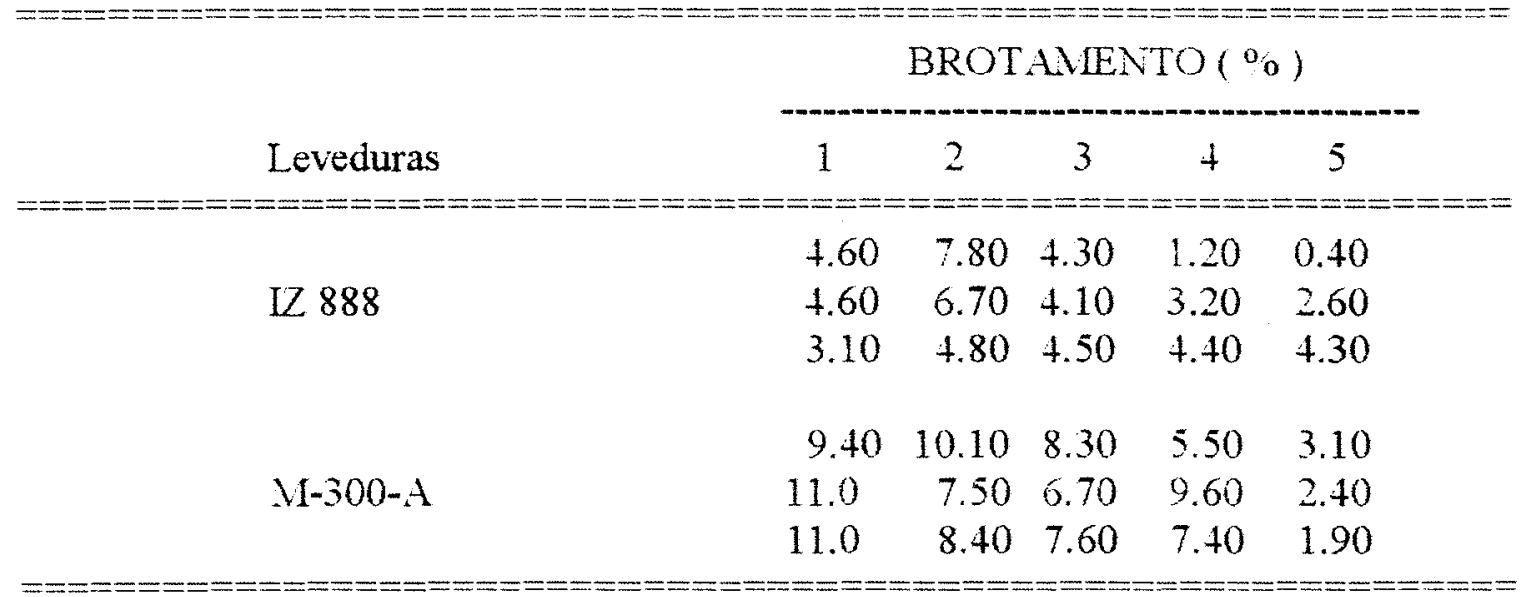

QUADRO DA ANALISE DE VARIANCIA

\begin{tabular}{|c|c|c|c|c|c|}
\hline $\begin{array}{l}\text { Causas da } \\
\text { Variação }\end{array}$ & G.L. & $\mathrm{SQ}$ & $\mathrm{QM}$ & Valor $F$ & Prob $>F$ \\
\hline LEVEDURA & 1 & 127.0175185 & 127.015185 & 49.3163 & 0.01614 \\
\hline BLOCOS & 2 & 4.4580410 & & & \\
\hline RESIDUO & 2 & 5.1511360 & 2.5755680 & & \\
\hline PARCELAS & 5 & 136.6266955 & & & \\
\hline CICLOS & 4 & 197.0191848 & 49.2547962 & 10.7038 & 0.00037 \\
\hline LEV * CIC & 4 & 42.8600102 & 10.7150025 & 2.3285 & 0.10000 \\
\hline RESIDUO & 16 & 73.6256312 & 4.6016019 & & \\
\hline TOTAL & 29 & 450.1315216 & & & \\
\hline
\end{tabular}


TABELA 26. Dados originais e analise de variância de $A R(g / 00 \mathrm{ml})$ para as levecuras IZ 888 e IZ 1904 após fermentação em meio de mosto de melaço com $12 \%$ de ART. alta concentração de inóculo e 4 reciclos de células.

\begin{tabular}{|c|c|c|c|c|}
\hline \multirow[b]{2}{*}{ Leveduras } & \multicolumn{4}{|c|}{ AR $(\mathrm{g} 100 \mathrm{ml})$} \\
\hline & 1 & 2 & 3 & 4 \\
\hline \multirow{3}{*}{ IZ 888} & 0.56 & 0.51 & 0.54 & 0.65 \\
\hline & 0.56 & 0.52 & 0.53 & 0.65 \\
\hline & 0.55 & 0.52 & 0.52 & 0.65 \\
\hline \multirow{3}{*}{ IZ 1904} & 0.51 & 0.53 & 2.65 & 7.23 \\
\hline & 0.53 & 0.52 & 2.65 & 6.90 \\
\hline & 0.53 & 0.54 & 2.71 & 7.17 \\
\hline
\end{tabular}

QUADRO DA ANÁLISE DE VARIÂNCIA

\begin{tabular}{|c|c|c|c|c|c|}
\hline $\begin{array}{l}\text { Causas da } \\
\text { Variação }\end{array}$ & G.L. & $\mathrm{SQ}$ & QM & Valor F & Prob $>F$ \\
\hline LEVEDURA & 2 & 0.0088083 & & & \\
\hline BLOCOS & 1 & 27.5418385 & 27.5418385 & 5467.3651 & 0.00032 \\
\hline RESIDUO & 2 & 0.0100750 & 0.0050375 & & \\
\hline PARCELAS & 5 & 27.5607218 & & & \\
\hline CICLOS & 3 & 44.7219133 & 14.9073044 & 3879.0257 & 0.00001 \\
\hline LEV * CIC & 3 & 41.7332471 & 13.9110824 & 3619.7990 & 0.00001 \\
\hline RESIDUO & 12 & 0.0461166 & 0.0038431 & & \\
\hline TOTAL & 23 & 114.0619988 & & & \\
\hline
\end{tabular}


TABELA 27. Dados originais e análise de variância de Glicerol $(\mathrm{g} / 100 \mathrm{ml})$ para as leveduras IZ 888 e IZ 1904 após fermentação em meio de mosto de melaço com $12 \%$ de $A R T$, alta concentração de inóculo e 4 reciclos de células.

\begin{tabular}{|c|c|c|c|c|}
\hline \multirow[b]{2}{*}{ Leveduras } & \multicolumn{4}{|c|}{ GLICEROL (g/100 mi ) } \\
\hline & 1 & 2 & 3 & 4 \\
\hline IZ 888 & $\begin{array}{l}0.52 \\
0.52 \\
0.51\end{array}$ & $\begin{array}{l}0.53 \\
0.54 \\
0.52\end{array}$ & $\begin{array}{l}0.56 \\
0.56 \\
0.55\end{array}$ & $\begin{array}{l}0.62 \\
0.62 \\
0.61\end{array}$ \\
\hline IZ 1904 & $\begin{array}{l}0.61 \\
0.62 \\
0.63\end{array}$ & $\begin{array}{l}0.67 \\
0.68 \\
0.68\end{array}$ & $\begin{array}{l}0.92 \\
0.91 \\
0.91\end{array}$ & $\begin{array}{l}1.01 \\
1.04 \\
1.02\end{array}$ \\
\hline
\end{tabular}

QUADRO DA ANÁLISE DE VARIÂNCIA

\begin{tabular}{|c|c|c|c|c|c|}
\hline $\begin{array}{l}\text { Causas da } \\
\text { Variação }\end{array}$ & G.L. & $\mathrm{SQ}$ & $\mathrm{QM}$ & Valor F & Prob $>F$ \\
\hline LEVEDURA & 2 & 0.0002333 & & & \\
\hline BLOCOS & 1 & 0.3876042 & 0.3876042 & 3322.3265 & 0.00040 \\
\hline RESIDCO & 2 & 0.0002333 & 0.0001167 & & \\
\hline PARCELAS & 5 & 0.3880709 & & & \\
\hline CICLOS & 3 & 0.2442125 & 0.0814042 & 1465.2765 & 0.00001 \\
\hline LEV * CIC & 3 & 0.1010458 & 0.0336819 & 606.2755 & 0.00001 \\
\hline RESIDUO & 12 & 0.0006667 & 0.0000556 & & \\
\hline TOTAL & 23 & 0.7339958 & & & \\
\hline
\end{tabular}

Média Geral $=0.682083$

Coeficiente de Variação $(A)=0.792 \%$

Coeficiente de Variação $(\mathrm{B})=1.093 \%$ 
TABELA 28. Dados originais e análise de variância da produção de etanol (\%) pelas leveduras IZ 888 e IZ 1904 após fermentação em meio de mosto de melaço com $12 \%$ de ART, alta concentração de inóculo e 4 reciclos de células.

\begin{tabular}{|c|c|c|c|c|}
\hline \multirow{2}{*}{ Leveduras } & \multicolumn{4}{|c|}{ ETANOL (\%) } \\
\hline & 1 & 2 & 3 & 4 \\
\hline \multicolumn{5}{|c|}{ 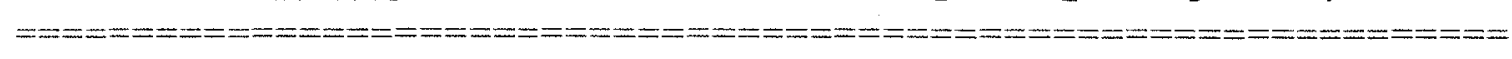 } \\
\hline \multirow{3}{*}{ IZ 888} & 5.86 & 6.56 & 6.56 & 6.56 \\
\hline & 5.86 & 6.56 & 6.70 & 6.56 \\
\hline & 5.93 & 6.56 & 6.70 & 6.56 \\
\hline \multirow{3}{*}{ IZ 1904} & 5.72 & 6.14 & 5.04 & 3.52 \\
\hline & 6.00 & 6.28 & 5.16 & 3.52 \\
\hline & 5.58 & 6.28 & 5.16 & 3.66 \\
\hline
\end{tabular}

QUADRO DA ANÁLISE DE VARIÂNCLA

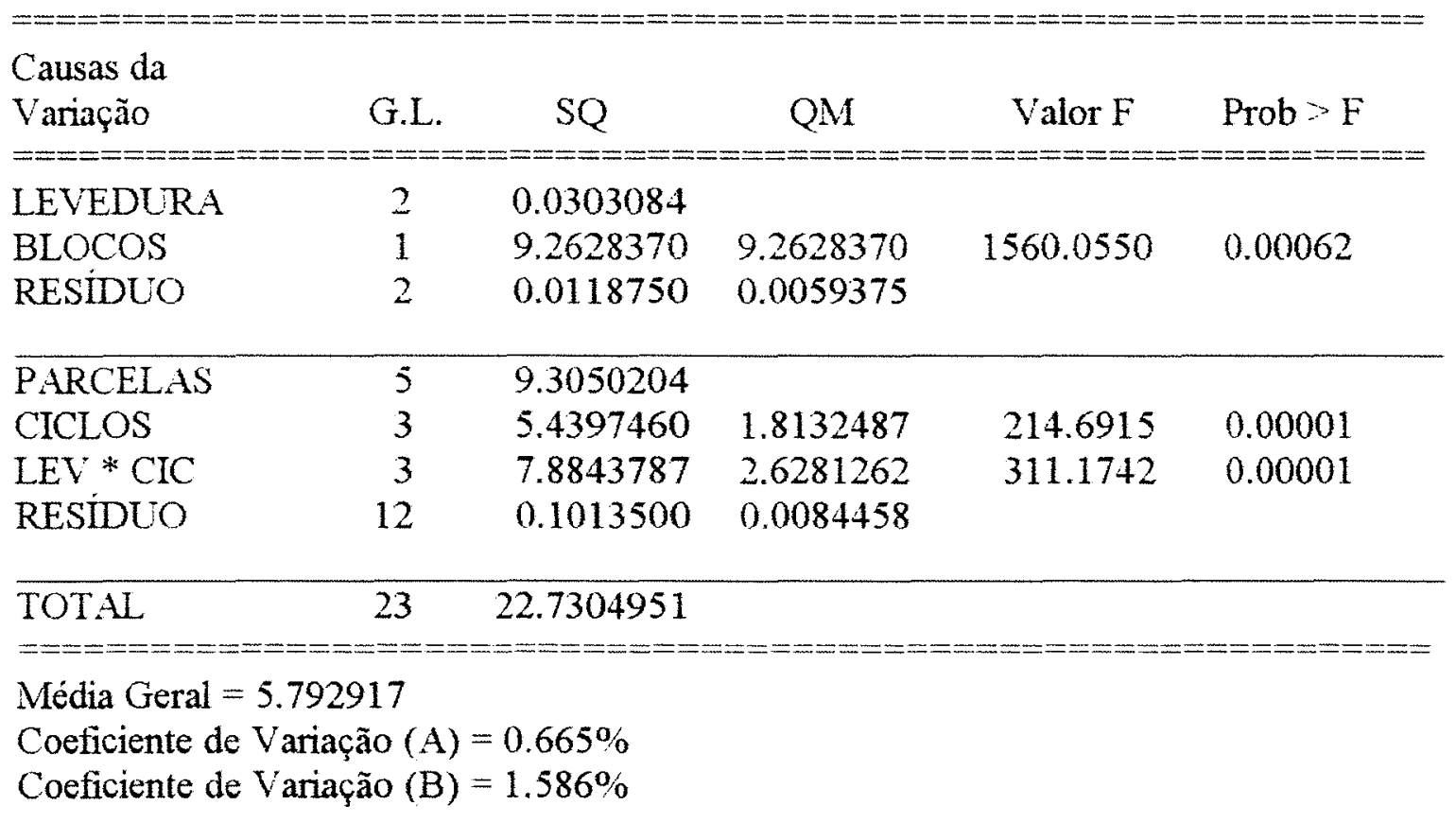


TABELA 29. Dados originais e analise de variância da Viabilidade celular $(\%)$ pelas leveduras IZ 888 e IZ 1904. após fermentação em meio de mosto de melaço com $12 \%$ de ART, alta concentração de inóculo e 4 reciclos de células.

\begin{tabular}{|c|c|c|c|c|}
\hline \multirow[b]{2}{*}{ Leveduras } & \multicolumn{4}{|c|}{ VLABLDADE $(\%)$} \\
\hline & 1 & 2 & 3 & 4 \\
\hline IZ 888 & $\begin{array}{l}73.60 \\
97.80 \\
94.70\end{array}$ & $\begin{array}{l}90.80 \\
91.70 \\
89.90\end{array}$ & $\begin{array}{l}85.10 \\
85.10 \\
80.50\end{array}$ & $\begin{array}{l}81.10 \\
82.10 \\
74.10\end{array}$ \\
\hline IZ 1904 & $\begin{array}{l}+7.90 \\
82.70 \\
73.60\end{array}$ & $\begin{array}{l}56.50 \\
53.70 \\
54.20\end{array}$ & $\begin{array}{l}48.50 \\
+0.30 \\
+7.20\end{array}$ & $\begin{array}{l}25.60 \\
24.20 \\
22.70\end{array}$ \\
\hline
\end{tabular}

QUADRO DA ANÁLISE DE VARIÁNCIA

\begin{tabular}{|c|c|c|c|c|c|}
\hline $\begin{array}{l}\text { Causas da } \\
\text { Variação }\end{array}$ & G.L. & $\mathrm{SQ}$ & QM & Valor $F$ & Prob $>F$ \\
\hline LEVEDURA & 2 & 92.1401059 & & & \\
\hline BLOCOS & 1 & 3613.2274164 & 3613.2274164 & 668.2606 & 0.00114 \\
\hline RESIDUO & 2 & 10.8138277 & 5.4069138 & & \\
\hline PARCELAS & 5 & 3716.1813500 & & & \\
\hline CICLOS & 3 & 1107.6774915 & 369.2258305 & 9.4960 & 0.00205 \\
\hline $\mathrm{LEV} * \mathrm{CIC}$ & 3 & 220.8736491 & 73.6245497 & 1.8935 & 0.18398 \\
\hline RESIDUO & 12 & 466.5858780 & 38.8821565 & & \\
\hline TOTAL & 23 & 5511.3183685 & & & \\
\hline
\end{tabular}

Média Geral $=56.172035$

Coeficiente de Variação $(A)=2.070 \%$

Coeficiente de Variação $(B)=11.101 \%$ 
TABELA 30. Dados originais e análise de variância de Brotamento ceiular $(\%)$ pelas leveduras IZ 888 e IZ 1904. após fermentação em meio de mosto de melaço com $12 \%$ de ART, alta concentração de inóculo e + reciclos de células.

\begin{tabular}{|c|c|c|c|c|}
\hline \multirow[b]{2}{*}{ Leveduras } & \multicolumn{4}{|c|}{ BROTAMENTO $(\%)$} \\
\hline & 1 & 2 & 3 & 4 \\
\hline \multicolumn{5}{|c|}{ 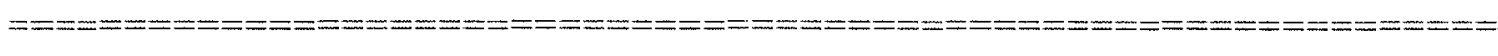 } \\
\hline \multirow{3}{*}{ LZ 888} & 6,20 & 9.70 & 5.30 & 7.60 \\
\hline & 6.60 & 8.70 & 7.20 & 3.40 \\
\hline & 6.70 & 8.60 & 5.90 & 6.20 \\
\hline \multirow{3}{*}{ IZ 1904} & 28.20 & 14.20 & 11.20 & +.60 \\
\hline & 13.20 & 11.30 & 11.60 & 12.10 \\
\hline & 16.80 & 11.20 & 9.80 & 8.70 \\
\hline
\end{tabular}

QUADRO DA ANÁLISE DE VARIÂNCIA

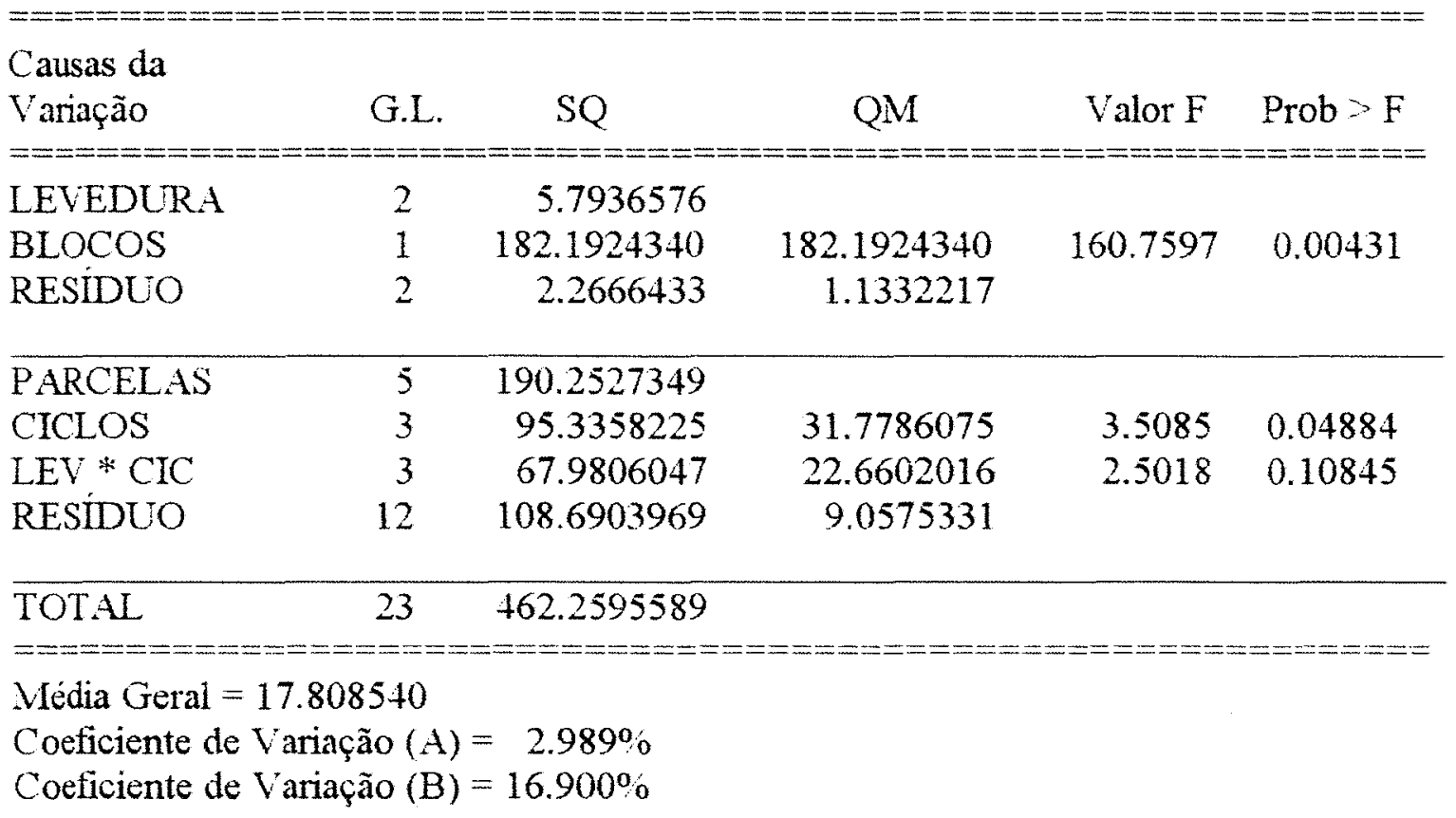

